\author{
UNIVERSIDADE DE SÃO PAULO \\ FACULDADE DE FILOSOFIA, LETRAS E CIÊNCIAS HUMANAS \\ DEPARTAMENTO DE FILOSOFIA \\ PROGRAMA DE PÓS-GRADUAÇÃO EM FILOSOFIA
}

RAPHAEL FELICIANO ALMEIDA

Versão original

\title{
A religião como representação na filosofia de Hegel: os manuscritos de 1821.
}




\title{
A religião como representação na filosofia de Hegel: os manuscritos de 1821.
}

\author{
Versão original
}

Dissertação de mestrado apresentada ao departamento de Filosofia da Faculdade de Filosofia, Letras e Ciêncas Humanas da Universidade de São Paulo para obtenção do título de mestre em filosofia.

Sob a orientação do prof. Dr. Marco Aurélio Werle. 
ALMEIDA, R. F. A religião como representação na filosofia de Hegel: os manuscritos de 1821. Dissertação apresentada à Faculdade de Filosofia, Letras e Ciências Humanas da Universidade de São Paulo para a obtenção do título de mestre em Filosofia.

Aprovado em:

Banca Examinadora:

Prof. Dr. Instituição:

Julgamento: Assinatura:

Prof. Dr. Instituição:

Julgamento: Assinatura:

Prof. Dr. Instituição:

Julgamento: Assinatura: 
Em memória de Vinicius Bertochi Martins. 


\section{Agradecimentos}

Ao professor Marco Aurélio Werle pela orientação e pela confiança desde o início de meus estudos na Iniciação Científica;

À Fundação de Amparo à Pesquisa do Estado de São Paulo, a FAPESP, pelo apoio institucional e pela concessão de bolsa de mestrado, processo: 2014/04439-0, sem a qual não seria possível ter concluído esse trabalho;

À minha família por ter me apoiado na difícil decisão de ter prosseguido meus estudos em filosofia, apesar de todas as renúncias e dificuldades decorrentes dessa escolha;

E, finalmente, aos meus amigos pelo apoio nos momentos em que tudo parecia não dar certo. Nomear cada um seria difícil e injusto com os que eventualmente fossem esquecidos, razão pela qual agradeço a todos de forma geral. 


\section{RESUMO}

O presente trabalho é uma dissertação que se destina a analisar a caracterização da religião através da noção de representação, notadamente nos manuscritos de Hegel elaborados em 1821 como notas de aula de suas preleções sobre a religião proferidas no mesmo ano. $\mathrm{O}$ intuito é esclarecer como a ideia de representação é central para marcar a posição da religião no sistema do Hegel maduro, bem como para apontar uma deficiência da religião como forma em relação ao pensamento conceitual e à filosofia. Para atingir esse objetivo, parte-se de uma análise da estrutura do sistema como um todo e da apresentação do conceito de religião nos referidos manuscritos, para finalmente investigar-se como a representação funciona para esclarecer a posição da religião no edifício da Enciclopédia das Ciências Filosóficas.

Palavras Chave: Hegel, religião, representação, sistema. 


\begin{abstract}
The present work is a dissertation that aims to analyse the description of religion through the notion of representation, specially on the Hegel's manuscripts written on 1821 as class notes of his lessons of religion given that same year. The focus is to clarify how the notion of representation is the key to hold the position of religion on Hegel's mature system, as to mark some deficiency of religion as form in relation to conceitual thought and philosophy. To achieve this goal, one starts from an analysis of the structure of the system as a whole and the statement of the concept of religion on the referred manuscripts, to finally investigate how representation works to clarify the position of religion on the building of the Encyclopaedia of the Philosofical Sciences.
\end{abstract}

Key Words: Hegel, religion, representation, system. 


\section{SUMÁRIO}

INTRODUÇÃO

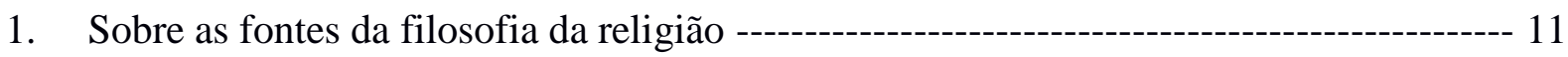

2. Sobre o propósito das preleções ----------------------------------------------------------------- 13

3. A cisão da consciência - o problema da incognoscibilidade de Deus. -------------------- 16

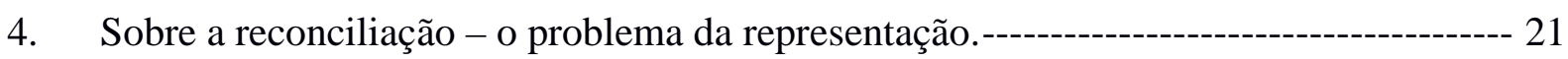

\section{CAPÍTULO I: AS NOÇÕES DE CONCEITO E ESPÍRITO NO SISTEMA DE}

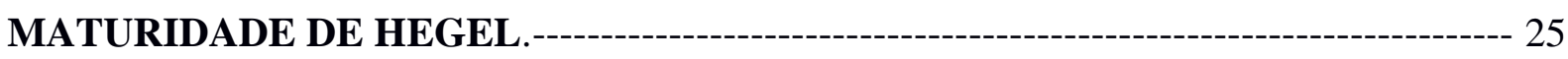

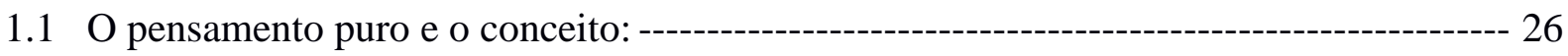

1.2 O princípio da filosofia----------------------------------------------------------------------------- 39

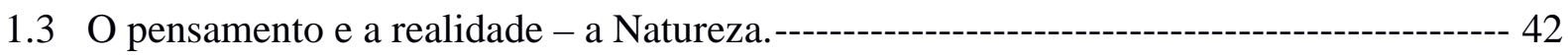

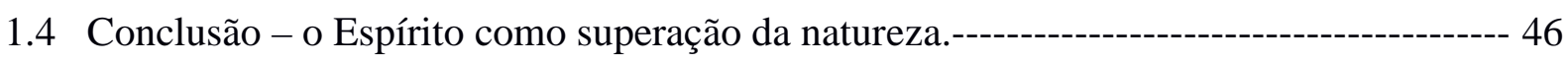

CAPÍTULO II: A RELIGIÃO NOS MANUSCRITOS DE 1821.------------------------- 50

2.1 Apresentação e relação dos manuscritos com a Enciclopédia das Ciências Filosóficas: - 50

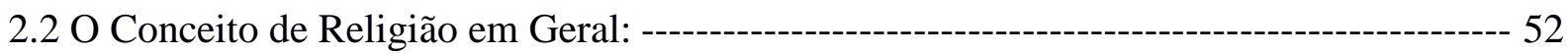

2.3 A concepção científica da religião. --- 57

2.3.1 A distinção entre a necessidade externa e interna. ------------------------------- 58

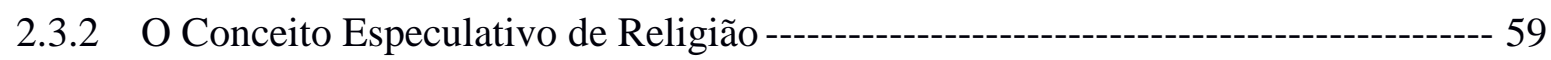

2.3.3 A Relação religiosa como unidade da absoluta universalidade e da absoluta

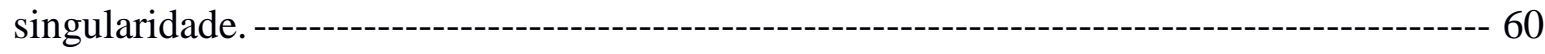

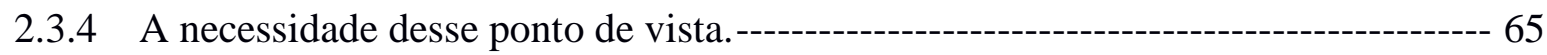




\section{CAPÍTULO III: A REPRESENTAÇÃO NO SISTEMA E A RELIGIÃO COMO}

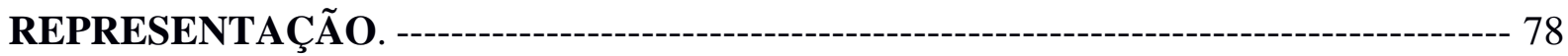

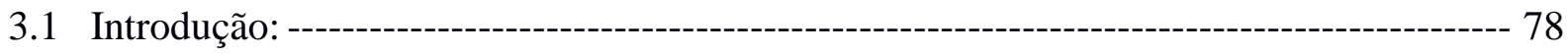

3.2 A representação no sistema - Caracterização como atividade do espírito teórico

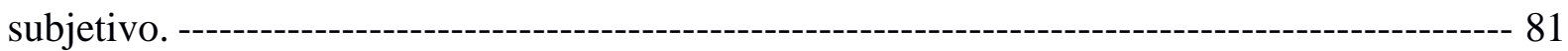

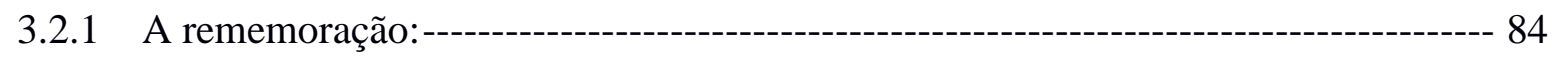

3.2.2 A Imaginação ---------------------------------------------------------------------------------- 85

3.2.1.1 A imaginação reprodutora:--------------------------------------------------- 86

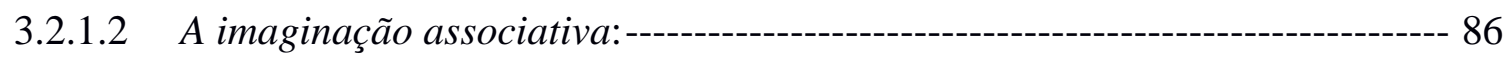

3.2.1.3 A fantasia ------------------------------------------------------------------------------ 87

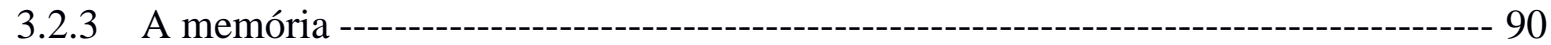

3.3 A religião como representação nos manuscritos de 1821. ---------- 93

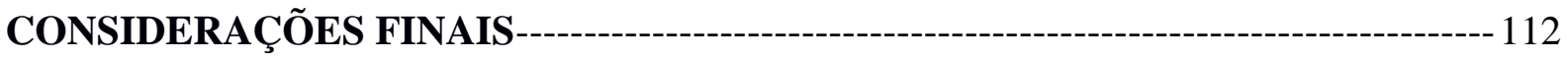

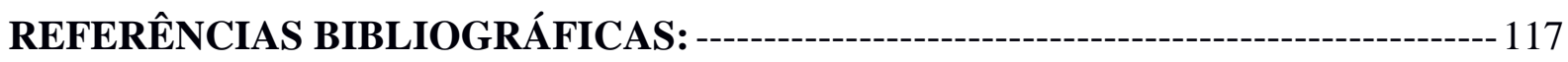




\section{INTRODUÇÃO}

O presente texto tem o intuito de abordar a religião sob o viés da ideia de representação segundo a exposição que Hegel fez acerca do tema nos manuscritos das Preleções Sobre a Filosofia da Religião de 1821. Portanto, nessa introdução, nos importa entender como o desenvolvimento do tema da relação entre o pensamento filosófico e a religião se depara com a questão da representação.

Sabemos que Hegel não tem uma obra publicada que se dedica somente ao tema da religião e que a questão aparece frequentemente como um assunto dentre outros no interior de obras diversas suas. Depois da Fenomenologia do Espírito, publicada em 1807, foram publicadas a Ciência da Lógica (em três partes, sendo que a primeira saiu em 1812), a Enciclopédia das Ciências Filosóficas (cuja primeira edição data de 1817. Ela seria reeditada mais duas vezes, em 1827 e 1830) e finalmente a Filosofia do Direito (de 1818).

O texto que será estudado aqui são as notas manuais de Hegel escritas como roteiro de um curso ministrado por ele sobre a filosofia da religião em 1821 na Universidade de Berlim. Depois do primeiro curso sobre a filosofia da religião ministrado no segundo semestre de 1821 na referida universidade, Hegel retomou o tema desses cursos mais três vezes, em 1824, 1827 e finalmente 1831, pouco antes de sua morte em uma epidemia de cólera em novembro deste ano. A abordagem sobre o tema da religião neste período, portanto, deve atentar para alguns pontos importantes.

Primeiramente, a referência conceitual utilizada por Hegel no decorrer do manuscrito diz respeito a esquemas conceituais do sistema presentes em outras obras. No caso da noção de representação, que é central para o desenvolvimento de nossa pesquisa, o tratamento da questão se dá especialmente na Enciclopédia das Ciências Filosóficas, na parte destinada a tratar do espírito subjetivo. Esclarecer o desenvolvimento do tema dos manuscritos implica analisar também como as questões estão ligadas entre estes textos.

E em segundo lugar, deve-se prestar atenção ao texto que é objeto de pesquisa. Indicamos aqui que a intenção é analisar a questão de acordo com os manuscritos sobre a filosofia da religião de 1821. Ora, sabe-se que ao contrário do que ocorre com a Estética de Hegel, cujo conteúdo chegou até nós por intermédio exclusivo de notas de aula de seus alunos, a filosofia da religião conta como fonte um texto manuscrito do próprio Hegel, muito 
embora as demais preleções sobre o tema não contem com esse recurso. Mesmo assim os manuscritos e os cursos da filosofia da religião passaram por diversas edições e polêmicas, razão pela qual pedimos licença ao leitor para nos determos sobre a questão das fontes para compreender melhor o trajeto intelectual pelos quais chegaram até nós o pensamento sobre a religião de Hegel, bem como nossa opção por este texto e não pelos outros.

1. Sobre as fontes da filosofia da religião

Dos quatro cursos que citamos anteriormente foram deixadas até o presente cinco edições: a primeira, de 1832, feita por Marheineke, a segunda, por Bruno Bauer e Marheineke, de 1840, a terceira por Lasson em 1929, a quarta, editada por Ilting em 1978, e finalmente a editada por Walter Jaeschke em 1983 para o Hegel-Archiv de Bochum.

Hegel escreveu um manuscrito que serviu de roteiro para o seu curso sobre a filosofia da religião ministrado em $1821 \mathrm{em}$ Berlim. Ao que tudo indica ${ }^{1}$ Hegel não teve a intenção de editá-lo, sequer publicá-lo, sendo que seu conteúdo seria desenvolvido posteriormente nas aulas. Como é basicamente sobre esses manuscritos que trataremos ao longo do trabalho, nele concentraremos nossos esforços de explicação sobre as fontes.

Os manuscritos cobrem o período de 30 de abril a 25 de agosto de 1821, o semestre letivo de verão na Alemanha. Ele não contém a assinatura de Hegel, sendo que seu nome foi adicionado por Marheineke na ocasião do depósito do texto na Real Biblioteca de Berlim, hoje a Staatsbibliothek Preussischer Kulturbesitz (biblioteca pública de cultura prussiana) ${ }^{2}$.

Esse manuscrito consta de cento e quatro páginas escritas em ambos os lados, totalizando 208 páginas. Não há certeza sobre a data exata em que eles foram escritos. Tanto podem ter sido acabados antes do curso ministrado na Universidade de Berlim ou terminado durante as exposições. Há uma folha avulsa dessas preleções depositada na Universidade de Harvard, na Houghton Library, com a data de dezesseis de julho, o que reforça a ideia de que

\footnotetext{
${ }^{1}$ Segundo relato de Marcelo F. Aquino, que faz uma longa análise sobre as fontes da filosofia da religião de Hegel em sua obra "O Conceito de Religião em Hegel". Sobre esse caráter ainda "incompleto" e seminal dos manuscritos, Walter Jaeschke também relata que "os manuscritos de suas preleções mostram sinais de terem sido compostos com pressa.” (JAESCHKE, W, 1986, p.229, tradução nossa)

${ }^{2}$ Segundo informação de Peter Hodgson na introdução à edição inglesa das preleções sobre filosofia da religião. Nesse caso, especificamente na edição citada, página 09.
} 
Hegel ia escrevendo o manuscrito durante as preleções. Há razões para se crer que o próprio filósofo tenha feito adições a esse manuscrito. Sabemos por relatos de seus alunos que esse texto foi usado como base para as lições de 1824. Isso se torna crível quando Hegel faz menção nas notas marginais a trechos de lições e obras escritas depois de 1821. Como exemplo, podemos citar as referências que surgem à Glaubenlehre de Schleiermacher, texto publicado após as preleções de 1821. A obra de Schleiermacher veio a público ainda em 1821, mas é muito pouco provável que Hegel tenha se familiarizado com ela tão rapidamente a ponto de tê-la citado cerca de um mês após sua publicação ${ }^{3}$. Contudo, como não se dispõe de anotações dos alunos desse curso em especial, é difícil para os historiadores conseguirem datar exatamente quando tais anotações foram feitas.

Outras fontes diretas são os chamados "Convolut", na tradução inglesa chamados de “Miscelaneous Papers". São anotações e rascunhos feitos pelos alunos de Hegel deste curso em questão. Como salientamos anteriormente, não há anotações desse curso disponíveis para nós nos dias de hoje, mas tais papéis foram utilizados na ocasião da preparação da segunda edição das preleções sobre a filosofia da religião, preparadas por Bruno Bauer e assinadas em conjunto com Marheineke. A primeira edição dos manuscritos foi levada a cabo por Marheineke e contou com o texto dos manuscritos e apontamento do aluno Griesheim para as preleções de 1824. Outros apontamentos de alunos foram utilizados para os demais cursos, os de 1827 e o de 1831. A primeira edição data de 1832, mas questões polêmicas envolvendo a cristologia de Hegel fizeram com que a preparação de uma segunda edição fosse elaborada.

Em 1835 veio a publico o texto "A Vida de Jesus" pelo trabalho de Strauss, e as discussões sobre esse texto começaram finalmente a dar força à distinção entre a "esquerda" e a "direita" hegeliana. Para sanar o problema, o filho de Hegel quis que Hotho editasse os textos de seu pai sobre a filosofia da religião, mas ele estava na época indisponível para esse trabalho. Coube a Bruno Bauer fazê-lo, sendo que o próprio Marheineke, editor da primeira edição, assinou como coautor, mesmo que Bauer tenha tido toda a liberdade e trabalho na construção do projeto.

Citamos a edição por parte de Bauer por uma questão importante. Ele utilizou na edição deste texto, especialmente no que diz respeito aos manuscritos, adições dos "Convolut" e das anotações de Leopold von Henning. O fato é que essas fontes foram perdidas, fazendo

\footnotetext{
${ }^{3}$ Posição relatada pelo citado Hodgson na introdução aos cursos sobre a religião em Berlim. Na edição inglesa, ver p. 10-11.
} 
com que o terceiro editor das preleções, Georg Lasson, criticasse fortemente a edição de Bruno Bauer, pois, para ele, a edição contém diversas paráfrases de Hegel, o que não se pode verificar devido à ausência das anotações referidas. É possível que os trechos criticados sejam pedaços desses apontamentos, conforme a posição de alguns estudiosos das fontes das preleções sobre a filosofia da religião no período berlinense ${ }^{4}$.

As obras posteriormente foram reeditadas por Ilting, mas no que diz respeito especificamente às preleções de 1821, pouca coisa foi alterada do original. O texto de Hegel, por ser um texto manuscrito, contém muitas abreviações difíceis de serem decifradas, bem como trechos incompletos. A transcrição desse texto foi feita na década de 80 por Walter Jaeschke, comparando com as edições de Ilting e a de Lasson.

A tradução inglesa que fazemos uso no presente texto é a tradução dessa transcrição de Jaeschke, que será a referência pela facilidade de consulta, cuja publicação se deu pela Felix Meiner Verlag. A opção que fazemos pelos manuscritos se baseia no que expomos aqui: é um documento muito importante por ser a única fonte direta do próprio Hegel que se possui sobre a filosofia da Religião no período de Berlim. Ademais, não há controvérsias tão fortes sobre fontes e edições em relação a esses manuscritos, o que faz com que a discussão sobre seus trechos não encontre muitas disparidades com outras edições. As citações feitas de Hegel dos manuscritos são tradução nossa, razão pela qual não mencionaremos o fato em todas as citações.

2. Sobre o propósito das preleções

Esclarecida a questão da fonte bibliográfica utilizada acerca das preleções sobre a filosofia da religião, resta explicar o propósito desse manuscrito, o que nesse caso, equivale a explicar o propósito de Hegel em ministrar um curso sobre esse tema justamente no tempo em que o fez. No espaço da introdução Hegel define o objeto, o fim e a divisão da filosofia da religião. Primeiramente, podemos dizer que seu objeto é Deus e a religião ${ }^{5}$.

\footnotetext{
${ }^{4}$ Dois que comentam esses fatos, são, especificamente, o já citado Hodgson na referida introdução à edição inglesa das preleções e aqui no Brasil o pesquisador Marcelo de Aquino que se deteve longamente nas fontes da filosofia da religião de Hegel. Sobre a afirmação que fizemos no texto, ver (Cf. AQUINO, 1989, pp 161 - 183).

${ }^{5}$ Segundo sugestão de Pierre Garniron, tradutor da versão francesa das preleções, em tradução da versão crítica de Walter Jaeschke. (HEGEL, 1996, p.LXXIX)
} 
No texto dos manuscritos, Hegel descreve a religião como uma atividade na qual os homens se libertam dos sofrimentos da vida cotidiana, numa relação onde se pode encontrar sempre piedade e compaixão. "O objeto da religião mesma é o mais alto, o absoluto, [...] o verdadeiro por si só (HEGEL, 1993, p.03)”. Isso só é possível porque Deus se mostra como o fundamento ou a substância absoluta de tudo que existe. E mostrando-se como o fundamento e fim de todas as coisas, "todas as pessoas têm, portanto, uma consciência de Deus, ou da substância absoluta, como a verdade de tudo e também de si mesmos, de tudo que são e fazem” (HEGEL, 1993, p.04). Há uma relação íntima entre o sujeito que crê e essa substância que é objeto da crença. "Investigar e tornar cognoscível essa natureza é o objetivo dessas preleções" ((HEGEL, 1993, p.05).

A explicação, contudo, se inicia por uma constatação de que nos tempos antigos havia uma identidade entre o pensamento e o divino. Logo de início vemos Hegel dizer que "o objeto dessas preleções é a filosofia da religião, que em geral tem o mesmo propósito que um tipo anterior de ciência metafísica que era chamada de "theologia naturalis" (HEGEL, 1993, p.03). Por aproximadamente uma página e meia, o filósofo alemão expõe o que entende ser uma identidade de objetos de estudo da filosofia da religião e dessa "ciência metafísica"6. Ele explica que a chamada teologia natural nada mais é do que o esforço metafísico empreendido pela razão para apreender a natureza de Deus com o esforço único do pensamento, sem lançar mão de intuições ou verdades reveladas. O que está em questão quando se equipara a filosofia com a teologia é a ocupação do pensamento com Deus ${ }^{7}$.

Nessa explicação sobre a ocupação do pensamento com Deus, Hegel constata que "havia um tempo em que toda ciência era ciência de Deus" (HEGEL, 1993, p.06). Em seu tempo, contudo, havia tantas ciências das coisas particulares que não restou ciência alguma para os assuntos divinos. Isso se dá pelo repúdio de seu tempo à pretensão de conhecer o absoluto, causado pela divisão das matérias das ciências particulares.

Apesar dessa negação, Hegel lembra que somente os humanos possuem religião, e que há algo de racional nela que não pode ser negado. À filosofia da religião, portanto, caberia tornar compreensível para a razão o objeto da religião, isso é, Deus. Nas palavras de Hegel,

\footnotetext{
${ }^{6}$ Jaeschke nos adverte, contudo, que a teologia natural que Hegel faz menção aqui não é a mesma coisa que a teologia especulativa que é a verdadeira manifestação do espírito para si mesmo. Provavelmente, aqui a intenção de Hegel é somente chamar a atenção para um tempo passado onde o pensamento era a via mais elevada de se apreender o absoluto. (Cf. HEGEL, G.W.F, 1993, p.XXII)

${ }^{7}$ As intenções de Hegel em tratar de temas teológicos não foram muito bem compreendidas em seu tempo. Muito se especulava se ele tinha o propósito de tornar os assuntos divinos um simples fenômeno humano ou se queria reinterpretar a doutrina cristã. (Cf. Hodgson, 2005, p.12)
} 
"Basta para o presente ter chamado a atenção para isso, e ter explicado que essas preleções têm o propósito de conhecer Deus, fazendo justamente o oposto do que é feito e do que se sustenta ser a última realização" (HEGEL, 1993, pp. 07 e 08).

Para levar a cabo esse propósito, Hegel divide a questão em dois aspectos: A relação da filosofia para com a religião pertencente a um sujeito e a relação da religião com o conhecimento $^{8}$. Tais aspectos, contudo, só podem ser opostos por haver outro problema que é central para a compreensão do desenvolvimento da explicação de Hegel. Sugerimos que o texto da introdução trata de uma questão central que deve ser solucionada por uma filosofia da religião, que é a cisão da consciência. A relação da filosofia com a religião implica uma divisão, como se houvesse uma consciência racional e outra crente. A questão é exposta nas seguintes partes ${ }^{9}$ :

a) A oposição da consciência religiosa (fé) com o resto da consciência (entendimento);

b) A necessidade da reconciliação dessas duas partes.

Antes de chegar a essa conclusão, é digno de nota que ele usa a palavra consciência frequentemente para caracterizar a atividade religiosa, bem como utiliza as palavras intuição e sentimento. Hegel inicia o segundo parágrafo dos manuscritos dizendo que a "Consciência é o que distingue os homens dos animais. Tudo que procede do pensamento [...] encontra seu centro último no pensamento único de Deus" (1993, p.03). Ora, essa afirmação não é fortuita, e ela se liga a um tópico levantado por ele logo em seguida, quando começa a desenvolver sua explicação sobre os propósitos da filosofia da religião, como vimos acima.

Se no início havia uma totalidade do pensamento que era referida a Deus, o que houve no desenvolvimento do pensamento que fizesse com que a situação chegasse ao ponto em que se encontrava quando foram redigidos os manuscritos, bem como todo o sistema da filosofia de Hegel? Nosso filósofo salienta que a escolha desse tema (a religião) tem relevância por causa da situação do pensamento acerca de Deus em sua época. Vejamos:

O interesse especial e a importância da filosofia da religião se baseiam aqui. Pois a doutrina de que nada podemos saber acerca de Deus, de que não conseguimos cognitivamente apreendê-lo, tornou-se em nosso tempo uma verdade reconhecida universalmente, uma coisa posta, um tipo de preconceito. E qualquer um que sustente o pensamento, ou tentar fazê-lo, de adentrar a cognição de Deus, ou compreender sua natureza no pensamento, consequentemente poderá esperar que

\footnotetext{
8 (Cf. AQUINO, 1989, p. 193).

9 Já levando em conta a divisão proposta por Jaeschke na edição crítica.
} 
ninguém lhe dará atenção, já que tal pensamento é tido como um erro há muito refutado, não merecendo maior atenção (1993, pp.05 e 06)

Para compreendermos a natureza dessa afirmação é necessário tentarmos entender em qual contexto ela foi escrita. A exposição dessa questão também é útil para entendermos o direcionamento que Hegel tomou em suas considerações acerca da religião. A "moda" do pensamento de que Deus é incognoscível envolve uma série de eventos intelectuais, e um deles é a chamada "a querela do panteísmo", diretamente ligado à recepção da filosofia de Espinosa e que envolveu grandes pensadores do cenário intelectual alemão nos tempos da formação intelectual de Hegel. Além disso, não podemos negar a influência dessa questão com a recepção da filosofia moral de Kant, o que teve grande impacto na formação dos ideais do movimento que mais tarde se chamou de "idealismo alemão", ao qual Hegel é referido.

3. A cisão da consciência - o problema da incognoscibilidade de Deus.

A cisão da consciência, além de ser um ponto de partida usado por Hegel nas preleções sobre a filosofia da religião, é um tema importante para todo o idealismo alemão. Como um todo, o movimento tenta pensar uma maneira de superar as oposições e recuperar um fundamento que seja a base comum do saber e do agir. Isso só seria possível com a supressão da cisão entre real e racional, entre sujeito e objeto, e em última instância, da razão prática e teórica ${ }^{10}$.

A cisão apareceu como um problema em grande parte devido aos desdobramentos e interpretações de Kant. Segundo o pensamento da filosofia crítica, não podemos conhecer nada de Deus usando a razão teórica, sendo que por esse meio ele é apenas pensável. A existência de Deus surge junto com a imortalidade da alma como um postulado da razão prática, já que era necessário para Kant um ser racional e eterno que desse garantia do

\footnotetext{
${ }^{10}$ Tal como surge na proposta de reforma do pensamento como um todo, que pode ser conferido no texto intitulado "O programa sistemático". De autoria controversa (discute-se calorosamente se foi escrito por Hegel, Schelling, Hölderlin ou os três juntos) este texto curto expõe a preocupação de uma geração em relação à submissão do ser humano ao modelo de existência burguês, baseado nos conflitos e relações da sociedade civil, cegos à relação com o todo: "Aqui deve ficar patente o que propriamente falta aos homens que não entendem Ideias - e com bastante sinceridade confessam que para eles tudo é obscuro, tão logo vá além de tabelas e registros." (SCHELLING. 1991, p.41.)
} 
cumprimento do sumo bem no mundo. Ao mesmo tempo, a alma deveria ser eterna para poder alcançar esse Bem, dada a temporalidade e a limitação da vida humana ${ }^{11}$.

Sustentando Deus pela via moral, abriu-se caminho para entender que Kant descartara a possibilidade de se poder conhecer racionalmente o divino e absoluto, abrindo-se o leque para inúmeras críticas. No período da redação das preleções, muito já havia sido formulado em termos filosóficos no sentido de suprir eventuais lacunas deixadas pela filosofia crítica, mas um evento que acentuou a questão da cisão e trouxe consequências para a forma de se compreender a religião, que é o nosso ponto, foi a chamada querela do panteísmo, na qual, através da recepção de Espinosa por parte de grandes nomes da cena intelectual alemã, como Goethe, Lessing, Herder e principalmente Jacobi, discutia-se a transcendência ou a imanência de Deus. Com Jacobi, a consequência disso também envolveu a capacidade de se conhecer Deus pela razão, aprofundando o abismo entre o finito subjetivo e o infinito objetivo.

A difusão do pensamento de Espinosa se deu principalmente por parte de Friedrich Heinrich Jacobi, autor de uma obra publicada em 1785, "Sobre a Doutrina de Espinosa em cartas ao Senhor Moses Mendelssohn"12. Trata-se de uma série de cartas destinadas a Mendelssohn relatando conversas que ele, Jacobi, tivera com Lessing acerca da filosofia de Espinosa. O interesse de Jacobi, na verdade, era tecer uma crítica ao espinosismo, entendido como o racionalismo elevado ao mais alto grau. Se por um lado Espinosa era tido em alta conta por ter um pensamento capaz de sustentar o ideal de retorno a uma unidade total com a

\footnotetext{
${ }^{11}$ Kant diz na Crítica da Razão Prática: “a lei moral conduziu ao problema prático, imposto simplesmente pela razão pura sem nenhuma participação de motivos sensíveis, a saber, da necessária completude da primeira e principal parte do sumo bem, a moralidade, e, como esse problema só pode ser resolvido inteiramente em uma eternidade, conduziu ao postulado da imortalidade. Essa mesma lei tem de remeter também, tão desinteressadamente como antes a partir de uma simples razão imparcial, à possibilidade do segundo elemento do sumo bem, a saber, a felicidade adequada àquela moralidade, ou seja, à pressuposição da existência de uma causa adequada a esse efeito, isto é, a postular a existência de Deus como necessariamente pertencente à possibilidade do sumo bem.” (KANT, 2003, pp.442 e 443). Walter Jaeschke aponta que a influência da filosofia crítica de Kant é o ponto de partida de Hegel em sua avaliação da situação da filosofia e da consideração que o pensamento adotou acerca da religião. Essa avaliação é importante para o desenvolvimento da filosofia hegeliana como um todo, não somente no que diz respeito ao conhecimento de Deus. Sobre esse tema, (Cf. JAESCHKE, 1986, pp. 24-26).

${ }^{12}$ Contudo, muito antes da publicação da obra de Jacobi sobre a doutrina espinosana, Goethe já havia relatado seu interessa na leitura do autor holandês. Em "Poesia e Verdade", no livro XIV, é dito por Goethe que a leitura de Espinosa o auxiliou na aproximação do modo de pensar de Jacobi, e "encontrava infinitos atrativos na tendência original e natural de Jacobi para a busca do impenetrável." (GOETHE, J.W. 1986, pg. 470) Sobre o filósofo holandês, é dito por Goethe que "Esse espírito, que exercia sobre mim uma ação tão decidida e que teria tão grande influência sobre minha maneira de pensar, era Spinoza. Como efeito, após ter procurado em vão no mundo inteiro um meio de cultura para minha estranha natureza, acabei por deparar-me com sua Ética" (GOETHE, J.W. 1986, pg 470). Para Goethe e Herder, que mantinham relação de intensa troca de ideias acerca da natureza, o pensamento de Espinosa significou uma abertura para a interpretação da natureza como processo imanente, onde tudo se cria e tudo se destrói (cf. BECKEMKAMP, J. p. 09).
} 
natureza, Jacobi via nisso um problema, pois apesar de concordar com Lessing que "não há outra filosofia além da filosofia de Espinosa" (JACOBI, 2000, p.23, tradução nossa), para Jacobi o sistema espinosano se configura como um sistema de pensamento no qual tudo pode ser deduzido de um Ser. Questionado sobre a natureza do Espinosismo, Jacobi responde que o espírito dessa filosofia é o antigo princípio do "a nihili nihil fit" (nada surge do nada), de acordo com o qual qualquer coisa que surgisse no infinito seria um surgir no nada. Por esse motivo, Jacobi rejeita passagens entre o finito e o infinito, especialmente causas transitórias e intermediárias, colocando no lugar um Ser imanente. ${ }^{13}$

Assim, no apêndice VII "Sobre a Doutrina de Espinosa", Jacobi expõe a sua explicação sobre como, para o entendimento, o incondicionado sempre aparece como algo condicionado $^{14}$. O argumento é que o pensar sempre se limita diante do seu objeto, não podendo operar uma passagem para ele. Ou seja: apreender um objeto é sempre fazê-lo na forma de algo condicionado pelo pensamento. Dessa forma, o incondicionado, o infinito, sempre aparece como algo mediatizado pelo pensar. Conhecer algo é, portanto, sempre conhecer algo finito, na medida em que o pensamento quando deduz algo sempre parte de um condicionado para outro condicionado. Mesmo uma condição inicial de uma sequência é condicionada e finita. A certificação da verdade dessas condições é impossível, pois implicaria um salto além do pensamento. Dessa forma, todas as condições do pensar têm validade apodítica $^{15}$.

Com essa explicação, as determinações de Deus e do infinito ficam excluídos do pensamento racional, sendo que a única forma de se alcançar o infinito, para ele, era através do sentimento, dessa crença que nos fazia acreditar em todas as evidências do mundo. Assim, em relação a Deus, era a fé que nos unia a Ele e não o entendimento, que deveria ser posto de lado nessa questão. E é essa posição que Hegel diz ser o preconceito de seu tempo. Desde o início de sua carreira intelectual Hegel tivera preocupações com a questão resultante da querela do panteísmo. Em 1802 redigira um artigo intitulado Fé e Saber, no qual criticava as posições de Kant, Jacobi e Fichte como filosofias da reflexão, que no fundo, tinham o mesmo resultado: o fechamento da subjetividade em si mesma, abandonando o objetivo como uma

13 Tal como exposto longamente pelo próprio Jacobi no referido texto, especificamente nos trechos que vão da página 23 à 24 da presente edição. (JACOBI, 2000, p.23 e 24).

${ }^{14}$ Deus somente é que é o indiferenciado. Conforme suas palavras, "O Deus de Espinosa é o mais alto princípio de efetividade em todo o efetivo". Mais adiante: "A unidade desse Deus repousa na identidade da indiferenciação”. (JACOBI, 2000, p.271, tradução nossa). Esse adendo VII foi citado por Hegel na Enciclopédia das Ciências Filosóficas, especificamente na pequena Lógica, parágrafo 62.

${ }^{15}$ Cf JACOBI, 2000, p.282, 283. 
esfera vazia. Sobre essa posição, citamos um trecho de Hegel no referido artigo Fé e Saber no qual ele afirma que

\begin{abstract}
A razão - que desse modo já tinha descido em si e por apreender a religião apenas como algo positivo, mas não idealmente - não pode fazer nada de melhor depois da luta do que daqui para diante olhar para si mesma, chegar ao seu conhecimento de si, reconhecendo o seu não-ser ao pôr, já que é apenas entendimento, o que é melhor que ela mesma em uma fé fora e acima de si, como um para-além, tal como aconteceu nas filosofias de Kant, Jacobi e Fichte, e reconhecendo que ela se fez novamente criada de uma fé $(2007$, p.20)
\end{abstract}

A rejeição da mediação do pensamento entre o objetivo e o subjetivo foi tema da criação do sistema hegeliano, como veremos adiante. Na Enciclopédia das Ciências Filosóficas, numa seção especialmente destinada a explicar o saber imediato, é justamente Jacobi que é criticado diretamente :

conceber um objeto aí não significa senão apreende-lo na forma de algo
condicionado e mediatizado, [e] por isso - enquanto é o verdadeiro, o infinito, o
incondicionado - transformá-lo em um condicionado e mediatizado, e dessa
maneira, em vez de apreender, pensando o verdadeiro, antes convertê-lo em não
verdadeiro. [...] Jacobi expôs essa argumentação polêmica de maneira mais rigorosa,
que aliás tinha haurido da filosofia de Espinoza e utilizado para combater o
conhecimento em geral (1995, p. 140)

Ainda na Enciclopédia, criticando-se o saber imediato:

o saber imediato sobre Deus deve estender-se somente a [intuir] que Deus é, não o que Deus é - pois esse último seria um conhecimento e levaria a um saber mediatizado. Assim, Deus, como objeto da religião, é expressamente limitado ao Deus em geral, ao supra sensível indeterminado; e a religião, em seu conteúdo, é reduzida a seu mínimo $(1995$, p.151)

Nos Manuscritos Hegel não se aprofunda na crítica ao saber imediato na introdução, limitando-se a colocar a questão como um problema a ser superado. O que está em questão ali é que dada a inacessibilidade do saber ao absoluto e a Deus, temos uma consciência dividida em um entendimento finito e uma consciência do infinito baseada no sentimento e na intuição. O resultado da não possibilidade do conhecimento de Deus é o ápice do processo de diferenciação da consciência, fazendo com que ela, inicialmente uma, se torne duas. "Elas constituem dois tipos de ocupação, entre as quais vamos de uma para a outra somente alternadamente" (HEGEL, 1993, p.11). Num trecho que se prolonga por volta de dez páginas, aproximadamente da página 11 à 23, Hegel explica como entende o desenvolver dessa separação, e como a oposição se estabelece a partir do lado da consciência "científica", do entendimento.

Assim, inicialmente, temos a consciência piedosa que é o aspecto da consciência que tem uma fé inconteste em Deus. É uma justificação de todos os aspectos da vida sob divino 
que é seu sustentáculo. A vida é então vista em todos os seus aspectos como um presente de Deus, mas, de outro lado, a outra parte começa a surgir a partir do mesmo ponto: o mundano que passa a ser explorado pelas faculdades humanas e suas potencialidades. O homem passa a entender as coisas como trabalhos do espírito, como obra humana, já que o entendimento compreende tudo como pertencente a ele. Muito embora a religião ainda seja pensada como a ocupação com o eterno e supremo, aqui tem início uma antítese ${ }^{16}$; de um dos lados o espírito reconhece o mundo como a si mesmo, do outro, reconhece um poder superior que condiciona tudo.

Para Hegel não existe uma separação absoluta das duas posições, e no instante em que a atitude científica reconhece que seus meios e fins são condicionados a algo exterior, a consciência científica tem que admitir que tudo provém de Deus. O problema é que essa é uma concessão vazia. "Ela é infrutífera pois nessa separação ela se detém na simples generalização de que tudo é obra de Deus" (HEGEL, 1993, p.15). É como se tudo no mundo fosse posto definitivamente pela atividade divina.

A posição piedosa se mostra como um juntar tudo em uma coisa só proveniente de Deus. A relação do conhecimento é justamente o oposto dessa postura piedosa, pois o entendimento compara as coisas e as relaciona de modo a formar uma unidade. A ruptura começa quando a consciência piedosa tem que dar conta das relações teleológicas das coisas finitas. Se a relação piedosa é colocar tudo indistintamente como emanações do poder de Deus, ela não faz diferenciações entre o bom e o ruim. Se todas as coisas, mesmo as mais mínimas e ínfimas partes do mundo são propósitos divinos, a própria atividade de Deus é entendida por meio de atividades determinadas e finitas. A consequência dessa posição é que se o conteúdo é finito, logo, a finalidade é contingente. Poderíamos pensar que Deus proveu as serpentes com peçonha para que pudessem se defender e se nutrir. Por outro lado, outros animais possuem a capacidade de devorar serpentes, sendo imunes a seu veneno. Pode-se dizer que os dois casos têm um propósito, tanto a da preservação das cobras quanto dos bichos que as comem. Mas daí teremos que admitir que as duas finalidades são um meio para a existência de outra finalidade.

\footnotetext{
16 Esse processo descrito brevemente por Hegel nos manuscritos foi objeto de um longo capítulo na Fenomenologia do Espírito, intitulado "O Espírito Alienado de si mesmo, a Cultura". Nesse capítulo há um subtítulo chamado "O Conflito da Fé com o Iluminismo", no qual Hegel expõe o conflito que estamos retratando dos manuscritos. Vale lembrar que para Hegel, pelo menos na Fenomenologia do Espírito, essa consciência que se opõe ao Iluminismo não é a religião, mas simplesmente fé. A religião pressupõe uma unidade superior do espírito consigo mesmo, conforme veremos adiante.
} 
O progresso da cognição começa a entender a insuficiência desse tipo de explicação teleológica para se explicar a natureza de Deus. Nesse ponto, “isso não é mais uma piedade ingênua ou sentimento" (HEGEL, 1993, p.18), pois o contingente e finito que serve para mostrar a elevação de Deus não é apto para esse fim. O contingente pode ser e não ser, o que não se enquadra a uma potência absoluta como Deus. Nós sabemos por nosso saber cotidiano o que as coisas da natureza simplesmente são. Quando queremos saber as causas dessas coisas não nos basta dizer que Deus é a causa absoluta de tudo, pois o que nos interessa aqui é a causa específica delas, e não uma causa geral. Assim, busca-se na esfera finita a causa desses seres prescindindo-se totalmente de Deus par explicá-la.

Essas cognições constituem um domínio que chamamos ciências ou conhecimentos técnicos específicos. Elas não são religião e não tem nada a ver diretamente com a religião. Nelas, a cognição está lidando com suas próprias relações e conexões (HEGEL, 1993, p. 21)

Esse tipo de conhecimento, essa cognição, se move nas determinações do finito e não sai dessa esfera. Conhecer algo é conseguir conectar determinações diversas, em relações de causa e efeito, etc. Assim, a religião finalmente se opõe às "ciências positivas", na medida em que ela resguarda o sentimento daquela união com o ser superior, mas carece de entendimento. O entendimento, por sua vez, possui uma gama de conteúdos interrelacionados, mas sem um ponto de sustentação. As filosofias criticadas por Hegel no texto e que já examinamos acima, são reflexos dessa oposição. Há de se superar essa oposição, mostrando a necessidade do conceito da religião. Vejamos:

4. Sobre a reconciliação - o problema da representação.

Essa oposição da consciência em duas esferas deve ser superada pela filosofia da religião, que deve demonstrar a reconciliação do sentimento com a inteligência. A reconciliação é expressa, inclusive, pela própria religião cristã, para a qual devemos conhecer Deus. Em muitos instantes Hegel nos lembra que o espírito de cisão de sua época vai contra os mandamentos da religião cristã. "Sejais bom como o pai dos céus é bom" é um mandamento da doutrina de Cristo impossível de ser cumprido se declaramos nossa incapacidade de conhecer esse pai perfeito que está nos céus. Essa realização cristã depende intrinsecamente do uso da razão. 
Mas o que Hegel vê de específico na religião cristã para colocar a necessidade de reconciliação nela como talvez mais diretamente presente do que em outras religiões? Ele elenca três hipóteses, cujo desenvolvimento argumentativo é gradativo, sendo que a primeira hipótese fundamenta a segunda e assim por diante:

Primeiramente, a religião cristã tem por princípio básico a separação. Seu sentido só se sente a partir da divisão, numa forma que não se faz tão marcada nas outras religiões. $\mathrm{O}$ cristianismo é a religião que se inicia pela ruptura da unidade natural tranquila do espírito, causando angústia, sofrimento e resignação. Ao contrário da serenidade que se encontra em outras crenças, o cristianismo é conturbado pela oposição em sua natureza mais íntima. Essa divisão acarreta, como veremos mais a seguir, em se pôr o princípio do mal no negativo; nesse caso o homem que é afastado do espírito. A natureza humana no cristianismo é naturalmente má ${ }^{17}$. O saber, contudo, busca a reconciliação, embora a revelação não lhe seja dada pelo intelecto, mas pelo testemunho da fé.

O testemunho da fé é o segundo argumento de Hegel. Para ele, há uma forma de se reconciliar imediatamente pela sensação e pelo sentimento, que posteriormente se torna fé. Entretanto, a "fé cristã parte da representação de que não sou isso, [...] ela me põe novamente na divisão. Eu sou sujeito e questiono se a fé é o caso, se é verdade" (HEGEL, 1993, p.24).

Isso conduz ao ponto máximo do argumento que é o de que o cristianismo é uma doutrina e que a cognição e o intelecto são partes constitutivas dela. Explicamos: A razão, o intelecto e o entendimento, meios pelos quais buscamos confirmar a veracidade da fé, são relacionados a nós indivíduos especificamente. Nós somos nossos pensamentos e nossa liberdade consiste justamente nisso. A razão, o intelecto, a negatividade que é referida como mal é a marca do próprio homem. Quando o cristianismo anuncia a salvação da alma humana como indivíduo por seus atos livres, a religião nada mais faz que atribuir um lugar

\footnotetext{
${ }^{17} \mathrm{O}$ fato de Hegel partir dessa questão cristã em sua filosofia é muito interessante se levarmos em conta a posição que começou a se difundir o romantismo a partir de Rousseau, para quem a natureza humana é essencialmente boa e corrompida pelo tipo de sociabilidade que predominou em nossa história. Hegel foi crítico desse tipo de posição desde os tempos de seus primeiros escritos sobre filosofia política, posição que se manteve similar até os tempos de maturidade em Berlim. Na Enciclopédia das Ciências Filosóficas, Hegel critica a posição do direito natural como algo melhor que o estado civilizado especialmente porque no estado natural "o direito da natureza é o ser-aí da força, e o fazer-valer da violência, e um estado-de-natureza é um ser-aí da força bruta e do não-direito, do qual nada melhor se pôde dizer senão que é preciso sair dele.”(HEGEL, 1995, p.289). Muito embora nos iluministas de uma forma geral, especialmente Hobbes, descrevam o estado de natureza de forma brutal tal como Hegel o diz na Enciclopédia, houve muita tentativa de enaltecer a natureza humana em detrimento do homem social, especialmente no romantismo. Sobre o assunto, ver o escrito de Hegel "Sobre as maneiras científicas de tratar o Direito Natural", bem como "A Filosofia do Direito".
} 
fundamental para o finito e o mal na tarefa da salvação. Se Deus é manifesto para o homem pela revelação, por outro lado ele deve alcançar a beatitude por seus atos e sua liberdade.

Assim, sendo manifesta, a religião cristã fornece representações e pensamentos. Quando o cristianismo fornece representações sobre a natureza e a vida de Deus, ela fornece conteúdos que por mais representativos que sejam, são imediatamente pensamentos. É dessa maneira que o aspecto cognitivo se faz presente na própria natureza dessa religião. As representações fornecidas pela revelação, por outro lado, não são somente algo interior, mas dizem respeito ao próprio absoluto. As representações dadas se apoiam no senso comum da sensação e da intuição, mas vão além delas. Assim, a antítese entre o sentimento imediato e o pensamento reflexivo é trazida para o seio dessa religião.

Consequentemente, a religião cristã é essencialmente doutrina; ela oferece
representações e pensamentos. Mesmo que eles sejam representações de Deus e de
sua natureza e atividade, eles são, não obstante, representações do objeto e do
conteúdo universal, e dessa forma, são imediatamente pensamentos (HEGEL, 1993,
p.24)

Chegamos ao nosso ponto principal: se Hegel entende que a religião que melhor responde ao problema da oposição da consciência é a religião cristã ${ }^{18}$ e ela se dá essencialmente por meio da representação e do intelecto, resta explicar o que significa essa representação. Em que medida ela promove um avanço na reconciliação da consciência e do mundo que faltava anteriormente? Como ela marca a religião como um estágio que não promove essa reunificação completamente, já que o sistema aponta a filosofia como responsável por fazer isso? Como deveríamos compreender a seguinte afirmação de Klaus Vieweg: "a forma da representação é o lado ainda não superado, a partir do qual o espírito tem de passar para o conceito. Trata-se, portanto, da tradução da forma ou da linguagem da representação para a forma ou linguagem do conceito."’? ${ }^{19}$ (2007, p.15)

O primeiro passo na caracterização do conceito de religião como representação é entender o funcionamento do sistema de forma geral, para que possamos compreender como

\footnotetext{
${ }^{18}$ Sobre o fato do cristianismo ser o ponto máximo da religião no sistema hegeliano, citamos um trecho de Albert Chapelle que resume a posição de Hegel acerca dessa forma da religião: "O cristianismo é a religião que, historicamente, conclui e realiza a experiência religiosa da humanidade; ele é a religião da pura liberdade do sujeito "filho de Deus"; ele coincide, em seu nível representativo, com a revelação espiritual do espírito em seu logos. O cristianismo é, portanto, objetivamente, subjetivamente, absolutamente a Religião, a única verdade de todas as religiões" (CHAPELLE, 1971, vol.III, p. 51, tradução nossa). Esse trajeto que justifica o cristianismo como a forma mais "perfeita" da religião no sistema hegeliano será exposto ao longo dessa dissertação.

${ }^{19}$ A ideia de "tradução" para a passagem da representação para o conceito deve ser interpretada como uma mudança na forma de relacionar o sujeito com seus objetos, e não uma forma mais adequada para apresenta-los para a consciência. Essa mudança de perspectiva é fundamental para diferenciar a representação do conceito, como veremos no decorrer dessa dissertação.
} 
Hegel insere a religião no edifício do saber. Posteriormente analisaremos o conceito de religião como proposto pelos manuscritos e pela Enciclopédia das Ciências Filosóficas. O terceiro passo será analisar como Hegel entende a noção de representação em si, já que somos levados a crer, em muitas passagens, que ela trata a questão ora de maneira mais aberta, ora trata o conceito de maneira mais específica, como uma forma do espírito teórico objetivo. Finalmente, nos encarregaremos de apontar em qual aspecto do conceito de religião ela é representativa e como isso se desenvolve no sistema. 


\section{CAPÍtUlO I: AS NOÇÕES DE CONCEITO E ESPÍRITO NO SISTEMA DE MATURIDADE DE HEGEL.}

A ideia de espírito desempenha um papel central na filosofia madura de Hegel, sem a qual não é possível entender o funcionamento de seu sistema. A compreensão da religião, por sua vez, por ser parte primordial do chamado espírito absoluto, não pode prescindir da ideia de espírito para ser esclarecida. A própria explicação do que sejam as partes do sistema dependem intrinsecamente da noção de espírito, e é por esse motivo que faremos um esclarecimento prévio do que ele significa, bem como se relaciona com a ideia de conceito na filosofia madura de Hegel. O sistema especulativo, como mostraremos, é um desenvolvimento da filosofia do conceito.

Os esclarecimentos sobre a natureza do espírito surgiram em Hegel na Fenomenologia do Espírito, obra que ele pretendeu usar como uma espécie de introdução ao seu sistema ${ }^{20}$. Após a publicação Fenomenologia do Espírito em 1807, Hegel dedicou uma parte da Enciclopédia das Ciências Filosóficas à exploração do tema na terceira parte da obra, que se chama justamente a "Filosofia do Espírito". Como ele define espírito? Para compreender essa noção iniciamos a exploração do tema reproduzindo diretamente aqui as palavras de Hegel acerca do conceito de espírito:

O espírito tem para nós a natureza por pressuposição, da qual ele é a verdade e, por
isso, seu [princípio] absolutamente primeiro. Nessa verdade, a natureza desvaneceu,
e o espírito se produziu como ideia que chegou a seu ser-para-si, cujo objeto, assim
como o sujeito, é o conceito. Essa identidade é negatividade absoluta, porque o
conceito tem na natureza sua objetividade externa consumada, porém essa sua
extrusão é suprassumida, e o conceito tornou-se nela idêntico a si mesmo. Por isso o
conceito só é essa identidade enquanto é retornar da natureza (HEGEL, 1995, § 381.
p.15)

Esse trecho, inicialmente complexo, envolve uma série de noções do sistema hegeliano. Primeiramente notamos que há uma relação entre espírito e natureza, já que ele afirma que a verdade da natureza é o espírito. Em segundo lugar, há uma relação direta entre essas ideias e a ideia de conceito, pois Hegel também afirma que o espírito tem como sujeito e como objeto o conceito. O conceito também é relacionado com a natureza quando é dito que o

\footnotetext{
${ }^{20} \mathrm{Na}$ introdução à Ciência da Lógica ele presume que o trajeto da consciência até o puro pensar já tenha sido realizado e explicado pela Fenomenologia do Espírito, o que reforça, pelo menos inicialmente, a ideia de que essa obra tenha servido de propedêutica ao seu sistema.
} 
conceito tem na natureza "sua objetividade consumada". E é o retorno a partir da oposição a essa objetividade que faz o conceito ser idêntico a si mesmo, e consequentemente, espírito.

Para desatar esse nó, faremos uma exposição na qual essas partes vão se conectando gradualmente. Inicialmente explicaremos como Hegel constrói um sistema reinterpretando a noção de pensamento, colocando o conceito como parte central de seu sistema. Posteriormente faremos uma análise de como esse pensamento reinterpretado se torna espírito e sistema.

\section{$1.1 \mathrm{O}$ pensamento puro e o conceito:}

Começamos a explorar o tema usando o fio condutor apontado pelo comentador canadense de Hegel, Charles Taylor ${ }^{21}$, que credita à mudança na concepção de subjetividade e sua relação com a ordem exterior o ponto central do problema do idealismo alemão. Para ele, "a diferença essencial talvez possa ser formulada dessa maneira: o sujeito moderno é auto definitório, ao passo que, em visões anteriores, o sujeito é definido em relação a uma ordem cósmica" (TAYLOR, 2014, p.26). Isso vai diretamente ao nosso ponto no que diz respeito à relação da subjetividade com a natureza. Segundo a herança do pensamento da revolução científica do século XVII, o pensamento verdadeiramente relevante não é o conhecimento das causas finais, mas sim os conteúdos oriundos de verificações empíricas, o que permitia tratar a natureza como conjunto de relações contingentes sujeitas ao controle humano. A ordem das coisas não mais se pautaria por causas finais, mas por simples causas eficientes. ${ }^{22}$

O resultado foi uma alteração na própria forma de se enxergar o homem e o próprio entendimento. Uma vez que nós também somos objeto de nossa reflexão, o homem também se sujeitou ao mesmo tipo de tratamento que o resto da natureza. Assim, "a nova ciência incubou um tipo de entendimento do ser humano que é mecanicista, atomístico, homogenizador e baseado na contingência" (TAYLOR, 2014, p. 30). Apesar de o Iluminismo promover a liberdade, seu resultado foi uma subjetividade oposta a uma natureza objetificada. O sujeito que se auto define se coloca como algo já pronto que está diante das coisas como

\footnotetext{
${ }^{21}$ Segundo a tese de Charles Taylor, renomado comentador canadense da obra de Hegel, a noção de espírito surgiu como uma tentativa de resolver duas tendências opostas que surgiram como desenvolvimento da antropologia iluminista francesa: o pensamento que via a vida como uma totalidade expressiva, da qual o romantismo foi uma grande corrente, e o pensamento da liberdade moral humana.

${ }^{22}$ Cf Taylor, 2014, p. 23 a 31.
} 
são fora de nós, ao passo que o reino das coisas exteriores também nos inclui, pois também somos parte da natureza. Esse entendimento mecanicista objetifica a própria consideração de si do homem. O que se encontra em nós aparece como um conjunto de faculdades: paixões, sentimentos, pensamentos, etc. Com o intuito de afirmar a autonomia da subjetividade, o resultado dessa empresa do pensamento foi o exílio da subjetividade, a negação da vida do sujeito.

O projeto filosófico de Hegel de repensar essa relação parte da redefinição do que é pensamento com o intuito de conseguir superar essa oposição entre o pensamento e o mundo. Pensar, seguindo definição da "Enciclopédia das Ciências Filosóficas", "constitui somente a determinação universal ou o elemento no qual está a ideia enquanto lógica” (HEGEL, 2005, $\S 19$ p. 65). Isso quer dizer que o pensamento propriamente dito é a ideia, "não como pensar formal, mas como totalidade, em desenvolvimento, de suas determinações e leis próprias, que a ideia dá a si mesma” (HEGEL, 2005, §19 p. 65)

Segundo esse ponto de vista não podemos pensar a subjetividade como um agrupamento de faculdades distintas, pois essas "faculdades" [Vermögen] se apresentam como fixas e imutáveis, como se tal disposição fosse naturalmente dada. Isso nos impede de compreender a mutua implicação entre essas formas subjetivas e a natureza. A apresentação dessa crítica está presente no adendo ao $\$ 451$ da Filosofia do Espírito:

As diversas formas do espírito, que se situa no ponto de vista da representação, costumam [...] ser vistas como forças ou faculdades isoladas, independentes umas das outras. [...] Mas a apreensão verdadeiramente filosófica consiste justamente em ser concebida a conexão racional existente entre aquelas formas; em ser reconhecido o desenvolvimento orgânico, que nelas se produz, da inteligência (HEGEL, 1995, $\S 451$, p.235)

Ora, só podemos entender o que é a ideia lógica, isso é, o pensar, se compreendermos como se dá a crítica a esse entendimento estático e o desenvolvimento da inteligência.

Iniciamos expondo o que esse pensar não é. E para tanto basta seguirmos o itinerário de Hegel que critica, na primeira parte da "pequena lógica ${ }^{23}$ ", as psicologias do entendimento que dividem o pensamento em faculdades ${ }^{24}$. De acordo com essas psicologias, o pensamento

\footnotetext{
${ }^{23}$ A exposição de Hegel sobre a Lógica se deu, principalmente, na obra "A Ciência da Lógica". Na exposição geral de seu sistema Hegel iniciou pela parta da Lógica, e é a primeira parte de três da Enciclopédia das Ciências Filosóficas. Para diferenciar esse texto da exposição geralmente se refere a esse texto como a "pequena lógica".

${ }^{24}$ Uma clara explicação sobre essa questão aparece no artigo de José Pertille sobre as faculdades do espírito. Acerca das psicologias do entendimento ele nos define que: "tal concepção estática do espírito pressupõe a fixação de suas faculdades como se elas fossem parte de uma natureza referencial, ao abrigo de mudanças substanciais na sua constituição fundamental. A crítica hegeliana consiste em mostrar que dessa maneira perde-
} 
dividido em faculdades não consegue superar uma interpretação subjetiva do pensar, sempre posto em oposição ao mundo exterior. Essa visão sobre o pensamento não só é uma posição adotada pela filosofia moderna, como também é a posição que o senso comum tem mais próxima a si. Para a consciência ordinária, o pensamento não é a totalidade, o concreto, mas apenas uma das faculdades ao lado da representação e da sensibilidade, como nos lembra o próprio Hegel:

Tomemos o pensar em sua representação que fica mais próxima; então ele aparece: 1) primeiro em sua significação habitual subjetiva, como uma das atividades ou faculdades espirituais, ao lado de outras - da sensibilidade, da intuição, fantasia, etc (HEGEL, 1995, §20, p.69)

Por isso, trata-se, no fundo, de mostrar que todas essas faculdades não são partes isoladas do homem, mas estão interligadas de alguma forma na mesma atividade, que é o pensamento. O idealismo alemão, de uma forma geral, se debruçou sobre essa questão e tentou resolvê-lo de formas diversas. ${ }^{25}$

Na posição moderna que dissemos acima o exame prévio das categorias do conhecer deixou de lado a consideração sobre o ser das coisas, na medida em que o exame do próprio pensar tornou-se condição prévia de qualquer reflexão acerca dos objetos. Lentamente a ideia de fazer com que o lugar central de um sistema fosse ocupado por uma metafísica foi abandonada em prol de uma centralidade da Lógica como cumpridora do papel de fundamentação, chegando à concepção de um sistema da razão pura.

A tese de que o sistema de Hegel é uma tentativa de criar um sistema da razão pura, seguindo um caminho aberto pela Crítica da Razão Pura de Kant, é dentre outros comentadores, de Walter Jaeschke ${ }^{26}$. E a fundamentação dessa tese passa justamente pela relação que Hegel estabelece entre o pensamento e a objetividade, culminando sua fundamentação com uma Ciência da Lógica.

Inicialmente, segundo Jaeschke, Hegel não pretendia chamar a Ciência da Lógica como tal, mas simplesmente como Sistema da Lógica. Por muito tempo Hegel via a parte

\footnotetext{
se a característica racional do espírito, ou seja, a sua faculdade de autodeterminação, entendida como movimento de reposição espiritual dos conteúdos que ele naturalmente recebe" (PERTILLE, 2010, p.43).

${ }^{25}$ Marcuse se apoia nessa concepção para definir a causa do idealismo alemão como um movimento. "Poderia, no entanto, a estrutura do raciocínio individual (a subjetividade) produzir leis e conceitos gerais que pudessem construir os padrões universais de racionalidade? [...] Ao responder afirmativamente a estas questões, o idealismo alemão visava a um princípio unificador que preservasse os ideais de uma sociedade individualística e não sucumbisse a seus antagonismos" (MARCUSE, 2004, p.27).

${ }^{26}$ É justamente ele que aponta que Hegel tentara, ao longo de sua carreira nos primeiros anos, colocar a metafísica como "ciência da própria ideia" e a lógica como propedêutica ao sistema. (Cf. JAESCHKE, 2014, p.36 e 37)
} 
central de seu sistema como uma metafísica, posição que lentamente se modificou até a concepção de que essa parte central deveria ser a Lógica ${ }^{27}$. O abandono da tentativa de pensar uma metafísica em moldes pré-críticos foi deixado de lado justamente pela constatação de que a metafísica fora de vez desterrada por Kant e sua crítica. Como Hegel mesmo diz na primeira introdução da Ciência da Lógica,

quando a forma substancial do espírito se transformou, é de vez por todas algo vão querer conservar as formas da formação anterior; elas são como folhas murchas que são repelidas pelos novos brotos que já foram gerados em suas raízes (2016, pp. 26 e 27)

O grande avanço de Kant, portanto, é ter aberto caminho para a transformação da antiga metafísica em uma lógica. Bem, e por que esse lugar central do sistema deveria ser ocupado por uma lógica e porque a inspiração é kantiana? Segundo Jaeschke é porque em Kant finalmente a

a característica da razão é o sistemático do conhecimento, isto é, a ligação do mesmo a partir de um princípio". Por isso Kant projeta uma "unidade completa do sistema do entendimento" como "um sistema coerente segundo leis necessárias", portanto, a "unidade dos conhecimentos múltiplos sob uma ideia", um "sistema acabado da razão pura", e, nesse "sistema da razão pura", ele vê o fim ao qual a "propedêutica" ou "Crítica da Razão Pura” deve conduzir (2014, p.43)

Hegel entende a natureza do conceito a partir da Crítica da Razão Pura. Kant $^{28}$ é tido por Hegel na Ciência da Lógica como o filósofo que deu o primeiro passo importante para pensar a relação ente o conceito e a objetividade, avançando decisivamente para que a filosofia chegasse à verdadeira natureza do conceito. Para Hegel,

Kant introduziu essa consideração por meio do pensamento sumamente importante de que existem juízos sintéticos a priori. Essa síntese originária da apercepção é um dos princípios mais profundos para o desenvolvimento especulativo; ela contém o início para a verdadeira apreensão da natureza do conceito e é perfeitamente oposta

\footnotetext{
${ }^{27}$ CF. JAESCHKE, 2014, p. 37.

28 Muito embora a passagem de Kant para Hegel não seja direta, tendo muitos assuntos discutidos e aprofundados por muitos autores entre eles, Kant é o autor do qual Hegel parece partir diretamente, pois quando se trata de expor a sua concepção do que seja o pensamento e o conceito, é Kant o filósofo que é diretamente e longamente comentado ele. É em relação a Kant, por exemplo, que o modelo de conceito especulativo é contraposto, tanto na Ciência da Lógica quanto na Enciclopédia das Ciências Filosóficas. Devemos também mencionar a influência de Fichte na construção do projeto hegeliano, quiçá de todo idealismo alemão na consolidação desse projeto "aberto" pela crítica kantiana. O projeto de uma ciência que fosse capaz de deduzir as regras da lógica a partir de um princípio fundamental surgiu primeiramente com Fichte. É uma tentativa de fazer a lógica ir além da mera forma do entendimento. Podemos ler no §6 do Conceito da Doutrina da Ciência: "A saber, na doutrina-da-ciência conteúdo e forma estão necessariamente unificados. A lógica deve estabelecer a mera forma, separada do conteúdo; essa separação, já que não é originária, só poder ocorrer por liberdade. A livre separação entre a mera forma e o conteúdo seria então aquilo pelo qual se institui uma lógica. Chama-se tal separação abstração; desse modo, a essência da lógica consiste na abstração de todo o conteúdo da doutrina da ciência” (FICHTE, 1984, p.26).
} 
àquela identidade vazia ou universalidade abstrata que não é nenhuma síntese em si (2011, p. 187)

O que está em questão aqui ${ }^{29}$ A operação adotada na filosofia crítica visava justamente estabelecer uma análise das determinações da velha metafísica que tomava por verdadeiras os conteúdos de pensamento sem submeter à análise seus pressupostos. Segundo um ponto de vista imediato pensar dessa maneira parece ser pensar em sua mais livre manifestação, mas Hegel adverte que essa maneira de pensar da metafísica tradicional "não era um livre pensar, porque admitia suas determinações sem mais, como algo preexistente, como um "a priori" que a reflexão não tinha, ela mesma, examinado" (HEGEL, 1995, §41, p.109). Graças a isso, a metafísica tradicional foi capaz de fazer as mais diversas afirmações sobre o suprassensível sem promover uma crítica de seus conceitos envolvidos.

Kant, sobre a metafisica, afirma: "a metafísica, um conhecimento da razão inteiramente isolado e especulativo que através de simples conceitos (não como a Matemática aplicando os mesmos à intuição), se eleva completamente acima dos ensinamentos da experiência [...]" (1999, p.38), razão pela qual continuamente se enreda em contradições e se estabelece em solo pouco firme. Portanto, Kant entendeu ser necessário estabelecer uma análise da nossa própria capacidade de conhecer para poder traçar os limites seguros de uma metafísica futura. Assim, a Crítica da Razão Pura "é um tratado do método e não um sistema da ciência mesma; não obstante, traça como que todo o seu contorno, tendo em vista tanto seus limites como também toda a sua estrutura interna" (KANT, 1999, p.41).

O motivo dos elogios de Hegel a Kant aparece com clareza no prefácio da segunda edição da Crítica da Razão Pura, no qual Kant diz que

a crítica não é contraposta ao procedimento dogmático da razão [...], mas sim ao
dogmatismo, isto é, a pretensão de progredir apenas com um conhecimento puro a
partir de conceitos [...] sem se indagar contudo de que modo e com que direito
chegou a eles (1999, p.47)

Segundo a Crítica da Razão Pura, as formas do pensar não poderiam mais ser utilizadas sem o devido exame prévio, sendo que elas se tornariam o próprio objeto do conhecimento. "Assim, o que primeiro aparece na filosofia de Kant é o que o pensar mesmo deve examinar-se, [para ver] em que medida é capaz de conhecer" (HEGEL, 1995, §41,

\footnotetext{
${ }^{29}$ O propósito aqui não é fazer uma análise do ponto de vista de Kant, mas sim mostrar quais os pontos que são abordados por Hegel na ciência da Lógica. Portanto, o conteúdo apresentado aqui diz muito mais respeito à leitura hegeliana de Kant que uma interpretação da filosofia crítica por si só. Rubens Rodrigues Torres Filho aborda a relação do idealismo, especialmente Schelling, com o problema do fundamento da síntese abordado na filosofia kantiana no ensaio intitulado "A produção extrateórica da síntese", vide: TORRES FILHO, 2004, p.163-172).
} 
p.109). E a crítica tem por objetivo maior investigar a possibilidade do que ele chamou de ‘juízos sintéticos a priori”. Todo o problema desenvolvido por Hegel a partir de Kant tem como fundamento a discussão sobre a validade objetiva desses juízos, o que está diretamente relacionado, como acabamos de apontar, não só com a validade da metafísica como ciência, mas no caso de Hegel, da possibilidade do pensamento mesmo ser capaz de superar a oposição subjetivo/objetivo.

O que a crítica de Kant nos diz sobre o que é um conceito? Na análise sobre nossa capacidade de conhecer, Kant separou a exposição das regras de nossa sensibilidade em geral sob o título e estética transcendental. A lógica, por sua vez, trata de analisar as regras do entendimento. O entendimento, por sua vez, é a faculdade não sensível do conhecimento humano. Se o conhecimento não se der por intuições, oriundas da sensibilidade, ele só pode se dar por conceitos. "Conceitos, portanto, fundam-se sobre a espontaneidade do pensamento, tal como intuições sensíveis sobre a receptividade das impressões" (KANT, 1999, p.102).

Kant também explica que "nenhuma representação se refere imediatamente a um objeto" (1999, p.102), o que significa que um conceito sempre se refere a outra representação, que pode ser tanto uma intuição como outro conceito. Dessa maneira, o entendimento tem um conhecimento mediato dos objetos através do que pensa através de seus conceitos. "O entendimento não pode fazer outro uso desses conceitos a não ser julgar através deles" (KANT, 1999, p.102). Assim, “o entendimento em geral pode ser representado como uma faculdade de julgar” (KANT, 1999, p.103). Pensar, nessa concepção, nada mais é que julgar, no sentido de realizar uma síntese mediante uma regra. Observando os juízos do entendimento, Kant chegou às categorias, que nada mais são que a forma do entendimento quando julga, isso é, quando pensa. Essas categorias também são chamadas de "conceitos puros do entendimento".

Assim, a lógica pode se referir unicamente às regras do pensar em geral, sem referência alguma a objetos (e nesse caso é chamada de lógica pura, pois abstrai de todo conteúdo para analisar a forma do pensar em geral, e é estritamente formal), ou ela é uma lógica transcendental. Ora, se a lógica pensa as relações do conhecimento, é natural que exista uma lógica que não seja a geral, que não abstraia de todos os conteúdos para estabelecer as regras a priori e que não se refira somente a conteúdos puros, mas que seja uma lógica que leve em consideração a natureza dos objetos. Assim, a lógica transcendental faz referência à capacidade a priori de conhecer os objetos, atividade que a lógica geral não se ocupa, visto 
que não distingue a origem dos conhecimentos. A lógica geral pensa as relações de todo e qualquer conhecimento possível, sem qualquer referência à origem de seus conteúdos, se puros ou empíricos. Por considerar que existem conceitos que se refiram a priori aos objetos como atividades do entendimento é que devemos pensar uma ciência que considere como o entendimento pode pensar objetos totalmente a priori. Tal é a função da Lógica Transcendental. Como Kant mesmo diz,

a lógica transcendental possui diante de si um múltiplo da sensibilidade a priori,
apresentado pela estética transcendental, para dar aos conceitos puros do
entendimento uma matéria sem a qual seriam sem conteúdo algum, e, por
conseguinte, inteiramente vazios (1999, p.107)

As categorias, como conceitos do entendimento, atuam na construção do conhecimento sobre dados oriundos da sensibilidade. Segundo Kant,

Somente através deles [os fenômenos] tornam-se possíveis o conhecimento e a determinação de um objeto. Eles, portanto, fornecem primeiramente matéria para a inferência e não são precedidos por conceitos a priori de objetos, dos quais pudessem ser inferidos (1999, p.239)

Entretanto, os conceitos não se resumem somente a serem organizadores da experiência em uma síntese, mas também buscam o que condiciona toda a experiência. Assim, eles agem a partir da experiência e vão além dela. O que compreendem é algo do qual a experiência é apenas uma parte. Nesse sentido, os conceitos não são somente conceitos do entendimento, mas também conceitos da razão.

A denominação de conceito da razão, entretanto, mostra já preliminarmente que ele
não quer deixar-se limitar pelo âmbito da experiência, porque concerne a um
conhecimento, do qual cada conhecimento empírico [...] é somente uma parte e para
o qual, na verdade, nenhuma experiência efetiva jamais basta plenamente. Os
conceitos da razão servem para conceber, assim como os do entendimento para
compreender (as percepções) (KANT, 1999, p. 239)

Como seu uso não se restringe às percepções sensíveis, podemos dizer que o conteúdo dos conceitos de razão é justamente o suprassensível, o que abrange a experiência e está além dela, com a ressalva que o conhecimento só se aufere de fato ao que possui conteúdo sensível. O uso dos conceitos além desse limite está circunscrito no terreno do pensável, mas que por falta de estofo sensível não se constitui como um conhecimento.

Mas resta ainda uma questão importante a ser respondida, que é o fundamento, tanto dos conceitos de razão quanto os do entendimento. Segundo Kant, na dedução transcendental dos conceitos puros do entendimento, a síntese do múltiplo não pode estar contida na sensibilidade, pois ela é um ato espontâneo de nossa capacidade de receber dados sensíveis e formar representações. "Ligação é a representação da unidade sintética do múltiplo" (KANT, 
1999, p.121). Isso quer dizer que a ideia de ligação não pode ser fundamento da síntese, pois a unidade é que permite que tenhamos uma representação do que é ligação, já que ela nos mostra a unidade do múltiplo. Ela também não pode ser oriunda das categorias, pois as categorias são funções dos juízos, que pressupõe unidade dos conceitos. "Isto é: o conceito de síntese não pode ser primeiro e originário, pois pressupõe conflito e unidade. [...] Apenas e unicamente o um, em sua identidade, simplicidade e obviedade, não geraria síntese" (TORRES FILHO, 2004, p.167).

Consequentemente, precisamos procurar essa unidade mais acima ainda, a saber, naquilo que propriamente contém o fundamento da unidade de diversos conceitos em juízos, portanto, da possibilidade do entendimento, até mesmo em seu uso lógico (KANT, 1999, p.121)

Essa síntese é operada pelo "eu penso", a unidade sintética originária da apercepção. Dessa unidade sintética depende todo o uso do entendimento, e assim também, toda a organização da experiência. "Denomino também sua unidade de unidade transcendental da autoconsciência, para designar a possibilidade do conhecimento a priori a partir dela" (KANT, 1999, p.121). Segundo Hegel na Ciência da Lógica, esse resultado da filosofia kantiana foi o divisor de águas no que diz respeito à consideração da natureza do conceito, pois permitiu que se compreendesse pela primeira vez que a relação entre o eu e o entendimento não é uma relação exterior, como se os conceitos fossem propriedades de uma subjetividade que os possuísse:

Kant distingue disso a unidade subjetiva da consciência, a unidade da representação, se sou simultânea ou sucessivamente consciente de um múltiplo, o que depende das condições empíricas. Os princípios da determinação objetiva das representações, ao contrário, teriam de ser unicamente deduzidos do princípio da unidade transcendental da apercepção (HEGEL, 2011, p.182)

Isso quer dizer que as categorias são os princípios da determinação objetiva com os quais é possível se constituir um objeto. Algo só pode ser considerado um objeto se o múltiplo recebido das intuições estiver unificado e organizado segundo as regras do pensamento. É o entendimento, portanto, que possibilita a experiência. Em termos hegelianos, significa que "o conceituar de um objeto não consiste em outra coisa senão que e o eu se apropria do mesmo, o penetra e o leva à sua forma própria, isto, à universalidade que é imediatamente determinidade ou determinidade que é imediatamente universalidade" (HEGEL, 2011, p.182).

O ser independente que os objetos da percepção possuem é transformado em um serposto pelo nosso pensamento, pois ele é um fenômeno percebido pela intuição e pela 
representação inicialmente ${ }^{30}$. É o pensamento que vai além dessa determinação e o coloca como algo posto, e desta maneira, a objetividade do objeto é conferida pelo próprio conceito, cuja unidade é permitida pela unidade da consciência de si, o eu penso citado acima.

Entretanto, Hegel entende ter ido além de Kant nesse sentido, pois para ele a filosofia crítica não compreendera o conceito como realidade, e sim como algo subjetivo que unicamente pudesse proporcionar experiências. Para Hegel, o conceito não é simplesmente uma faculdade que permite que se constitua objetos em experiências, mas sim a realidade concreta mesmo. A filosofia crítica de Kant não consegue avançar além de uma organização subjetiva porque faz a síntese depender sempre de um conteúdo dado na experiência sensível. Daí seu famoso adágio de que "pensamentos sem conteúdo são vazios, intuições sem conceitos são cegas" (KANT, 1999, p.92).

Por esse motivo, o que Kant denomina síntese não é ainda o que Hegel entende ser a verdadeira síntese operada pelo conceito, pois ela só liga o entendimento a um dado exterior, e assim se torna dependente dele. Nas palavras de Hegel:

Já a expressão síntese conduz facilmente de novo à representação de uma unidade exterior e uma mera ligação daquilo que é em si e para si separado. E, assim, a filosofia kantiana permaneceu presa apenas no reflexo psicológico do conceito e retrocedeu novamente para a afirmação da permanente condicionalidade do conceito por meio do múltiplo da intuição (2011, p.187)

E porque Hegel considera que a posição de Kant nesse sentido é falha e mantém um "reflexo psicológico"? Resta entender em que sentido Hegel parte da noção kantiana de conceito mas vai além dessa limitação imposta pela experiência sensível. Hegel se refere diretamente a esse problema: "Se permanecermos presos à mera representação do eu, tal como ela se mostra à nossa consciência comum, então o eu é apenas a coisa simples, que é também denominada alma, a qual o conceito é inerente como uma posse ou propriedade" (2011, p.183).

O que nos importa no momento é a relação da ideia de eu e do conceito, pois no eu já se expressa uma relação de sujeito e objeto. A atividade de unificação das representações pressupõe uma unidade da própria consciência operando na síntese. Em outras palavras, é somente o fato da consciência ser a própria unidade entre o subjetivo e o objetivo que podemos pensar em uma síntese.

${ }^{30}$ Cf, Hegel, 2011, p. 182. 
Retomando a explicação sobre a atividade do conceito, temos que da intuição recebemos inicialmente os dados de um objeto que é "em si". Ele é algo nele mesmo, independente de nós. Mas por nosso intuir e nossa força de representação, esse objeto passa a ser fenômeno, algo que surge em nossa consciência, e é para nós. Dessa maneira, pelo pensar, esse objeto que antes era apenas "em si", passa a ser "para nós", ou seja, é um ser posto, um objeto. Devemos notar que o objeto só se torna objeto pelo fato de ser-posto pelo pensamento, já que essa posição é um momento do pensar, que, inicialmente, o acolhe como dado e o põe como algo diferente de nós. Se a atividade das categorias (o próprio conceituar) é possibilitada somente pela unidade do eu, no qual a síntese se opera, é justo dizer, como Hegel o faz, que a atividade do conceito nada mais é que determinação do próprio eu.

O objeto tem essa objetividade, desse modo, no conceito e esse é unidade da consciência de si, na qual ele foi acolhido; sua objetividade ou o conceito é, por isso, ele mesmo, nada mais do que a natureza da consciência de si, não tem outros momentos ou determinações senão o eu mesmo (HEGEL, 2011, p.182)

Por essa razão, segundo o ponto de vista de Hegel, a subjetividade, ou o conceito, já guarda em si a diferença e a unidade; ele cria a realidade a partir de si mesmo, sendo que essa concepção se deriva da conclusão de que o conceito opera a objetividade dos objetos. No final das contas é o próprio conceito que opera a própria determinação. Hegel se diferencia de Kant na medida em que essa síntese não necessita de um dado sensível, mas é a própria atividade do conceito que supera essa dependência e se faz absoluto.

Isso se faz possível porque a atividade subjetiva do juízo (do qual Kant extrai as categorias) é uma atividade que por natureza relaciona conceitos que se relacionam externamente em relação um ao outro; ou seja: há um sujeito e um predicado que se relacionam mas mantém suas identidades opostas. Dessa maneira, o juízo é uma relação que tem em si sempre a unidade e a oposição. E é justamente essa relação dúplice que confere movimento e atividade a esse sujeito, e não um receptáculo de informações oriundas da sensibilidade.

Hegel identifica a atividade do conceito com o próprio eu, como a própria atividade subjetiva por excelência. E isso porque assim como ele,

o conceito é o [que é] livre, enquanto potência substancial essente para si, e é totalidade, enquanto cada um dos momentos é o todo que ele [mesmo] é, e é posto com ele como unidade inseparável; assim, na sua identidade consigo, o conceito é o determinado em si e para si (HEGEL, 1995, §160, p.292) 
De que forma? Bem, o eu assim como o conceito é inicialmente uma unidade consigo, que se alcança recolhendo a si mesmo negando as determinações e conteúdos exteriores. "Esse ser posto constitui a diferença do conceito nele mesmo; suas diferenças, porque são imediatamente o ser-em-si-e-para-si, são elas mesmas o conceito inteiro" (HEGEL, 2011, p.195). O que resta dessa abstração é a pura universalidade. "Assim ele é universalidade; unidade que apenas por meio daquela postura negativa, que aparece como o abstrair, é unidade consigo, e desse modo, contém dissolvido em si todo ser-determinado" (HEGEL, 2011, p.181).

Contudo, essa universalidade negativa é também um excluir o outro e manter a identidade abstrata consigo mesmo. Assim o conceito se faz uma particularidade. ${ }^{31}$ Nesses estágios o conceito ainda é algo apenas interior, ou seja, ele é entendido como algo marcadamente subjetivo. Ele ainda não pode se colocar como algo objetivo porque não consegue penetrar totalmente nas diferenças de seus momentos. Consequentemente, a realização dessa subjetividade do conceito se vê frustrada por uma marca da objetividade, que é o relacionar um ao outro exteriormente como no juízo. ${ }^{32}$ Se o conceito é o livre que só se relaciona consigo mesmo, ele deve superar essa oposição. O conceito, finalmente, se torna objetivo através do movimento dialético entre essas diferenças de seus momentos postos com a identidade que ele mantém consigo mesmo. A oposição dessas duas naturezas produz o conceito como totalidade, agora sim como algo objetivo, que nesse caso não é uma objetividade oposta ao subjetivo, mas sim uma efetividade.

Por meio de sua necessária determinação progressiva, o conceito formal torna-se a si mesmo uma questão [Sache] e perde, desse modo, a relação da subjetividade e a exterioridade contra ela. Ou, inversamente, a objetividade é o conceito real surgido de sua interioridade e que passou para a existência (HEGEL, 2011, p.196)

Quando o movimento do conceito atinge finalmente a identificação com a objetividade ele se torna ideia. No nível da ideia não há mais algo a se alcançar, pois ela é o verdadeiro em si e para si, sendo que a efetividade é a própria expressão da ideia. "O objeto, o mundo subjetivo e o objetivo em geral, não devem ser meramente congruentes com a ideia, e sim eles mesmos são a congruência do conceito e da realidade [...]” (HEGEL, 2011, p.233).

\footnotetext{
${ }^{31}$ A noção de particularidade do conceito se relaciona ao juízo, no qual relacionamos um sujeito e um predicado de maneira exterior. A relação é exterior porque um não se resume ao outro, permanecendo ambos os lados indiferentes entre si. Isso acontece porque o conceito que é meramente universal se coloca como a verdade abstrata do que é posto, de maneira que seus instantes opostos se tornam indiferentes. Somente no desenvolvimento do juízo o conceito passa a silogismo, que por sua vez tem os momentos opostos em uma unidade, negando a abstração anterior e colocando o conceito como algo objetivo.

${ }^{32}$ Posteriormente, na parte dedicada à explicação sobre a representação, nos profundaremos mais na questão sobre a exterioridade e a interioridade.
} 
A ideia é a exposição do pensamento em seu encadeamento necessário, pois resulta do movimento dialético das categorias do pensamento deduzindo-se gradualmente até o nível do ideal. Portanto, a congruência plena de um conceito e sua efetividade, ou seja, a realização de uma ideia é um evento necessário. Essa necessidade ocorre pela realização da liberdade do pensamento, pois ele deixa de ser determinado por algo exterior e se torna auto determinante. ${ }^{33} \mathrm{O}$ contingente, nesse sentido, é tudo aquilo que ainda não atingiu a congruência da ideia, o que significa que tudo o que ainda não está no nível supremo do pensamento tem uma elemento de contingência em si.

Hegel expõe essa conclusão de maneira clara em um trecho dedicado à ideia na Ciência da Lógica:

aquela realidade que não corresponde ao conceito é mero fenômeno, o subjetivo, o contingente, o arbitrário, que não é a verdade. [...] O objeto mecânico e químico, assim como o sujeito destituído de espírito e o espírito apenas consciente do finito, não de sua essência, possuem, na verdade, segundo sua natureza diversa, seu conceito não existindo neles em sua forma própria e livre (2011, p.233)

Esse trajeto exposto pela Ciência da Lógica permite entender como Hegel pretende ter superado as visões anteriores sobre a natureza do pensar e ter criado um idealismo absoluto. Seu mecanismo de identificação do conceito com a própria subjetividade confere movimento e atividade para o pensamento, e, na medida em que ele mesmo determina o efetivo, significa que a própria efetividade é perpassada e criada pela atividade pensante. Hegel compreende que sua filosofia do conceito finalmente pode superar a ideia de substância como objetiva e fixa e compreendê-la como processo, como sujeito. Esse é o grande motivo e a grande virada de sua filosofia. No prefácio da Fenomenologia do Espírito essa ideia é expressa diretamente quando ele diz que:

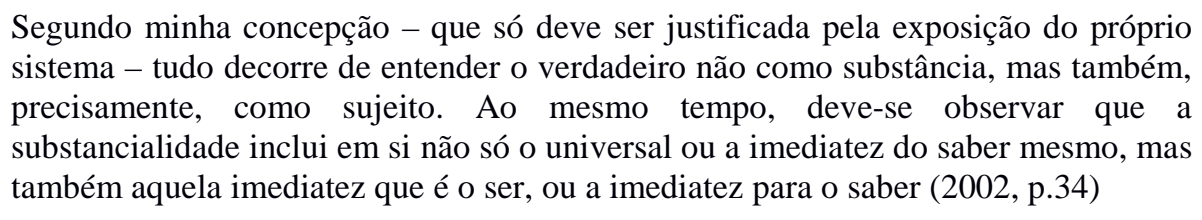

Esse movimento que ele confere ao pensamento deve, contudo, ser autorreferente para que o conceito seja de fato algo não condicionado por fora. Nesse caso, os momentos com o

\footnotetext{
${ }^{33}$ A questão da determinação exterior diz respeito à crítica que Hegel empreende na Ciência da Lógica contra o chamado "mau infinito", o infinito que é oposto à série finita de causas e efeitos. O verdadeiro infinito, argumenta Hegel, é o que não é determinado por nada exterior, em uma formulação similar à de Espinosa "omnis determinatio est negativo" (toda determinação é negação). Espinosa fez uso dessa expressão na carta 50, endereçada a Jelles. Sobre a relação de Hegel com questões da filosofia de Espinosa, ver MACHEREY, P. Hegel o Spinoza. Buenos Aires: Tinta Limón, 2006. Ou também DE GAINZA, M. Espinosa: Uma Filosofia Materialista do Infinito Positivo. São Paulo: Edusp, 2011, especialmente a primeira parte.
} 
qual o conceito se relaciona devem ser momentos de si mesmo e não de uma substância com o qual ele se relaciona. Caso a determinação do movimento fosse marcada por uma relação com uma substância que não fosse o próprio pensamento, seria o mesmo que trancar o movimento do pensamento na esfera subjetiva.

Hegel atentou a esse detalhe e o expôs com detalhes na sua exposição da Ciência da Lógica quando colocou a esfera do ser e da essência como momentos anteriores ao do próprio conceito. Basicamente, a diferença entre tais esferas é a forma de relação com a alteridade, com a objetividade. No nível do ser, o movimento impulsionado pela contradição é um devir no qual a mudança é sempre um passar para algo totalmente diferente de si, um ser ultrapassado por outro. Já no caso da essência há uma relação entre esses opostos, mas um é como se fosse o aparecer da alteridade. Surge uma relação de desvelamento de algo oculto, numa relação de substância e seu aparecer. "Passar para o Outro é o processo dialético na esfera do ser; e aparecer em Outro é [esse processo] na esfera da essência. Ao contrário, o movimento do conceito é desenvolvimento, pelo qual só é posto o que em si já está presente" (HEGEL, 1995, §161 adendo, pp.293 e 294).

Essa autoreferencialidade é o ponto onde se consegue perceber que nada está além ou aquém do pensamento, que o Outro nada mais é que o outro de si mesmo. "O movimento do conceito, de certo modo, pode-se considerar como se fosse um jogo apenas; o Outro, que por ele é posto, de fato não é Outro" (HEGEL, 1995, §161, adendo, p. 294).

As razões pelas quais o todo efetivo deve ser uma lógica são as que colocamos até agora. O pensamento perpassa tudo o que pode ser pensado e o identifica a si, fazendo com que o pensamento seja, no final das contas, autorreferente. Essa autossuficiência do pensamento elimina a necessidade de uma substância ou um sujeito exterior para ser pensado qualquer tipo de conteúdo, que se revela, no nível do conceito, como posição do próprio pensamento $^{34}$.

A questão que separa a dialética hegeliana de seus predecessores é a conclusão de que o pensamento puro não se confunde com uma teoria do conhecimento. Aliás, é justamente essa a razão pela qual Hegel teve de empreender uma exposição do ser e da essência antes de

\footnotetext{
${ }^{34}$ Com isso ganha força a questão do início da filosofia, pois se a lógica é a exposição do pensamento que põe a si mesmo, ela deve mostrar por onde devemos começar o trajeto até chegar a esse nível da ideia. O início deve ser imediato por ser começo, mas deve conter em si o fim, pois o fim é o fundamento de todo o sistema. O que ocorre é um iniciar de forma abstrata, cujo desenvolvimento faz com que encontre, ao fim do processo, ele mesmo, mas enriquecido pelas categorias do pensamento que são deduzidas umas a partir das outras. Por isso que se diz que em Hegel todo avançar é um retroceder ao início. (cf. Ciência da Lógica)
} 
abordar sua concepção sobre o conceito. Essa exposição tem o propósito de mostrar como o desenvolvimento de contradições postas nesses dois níveis conduzem ao nível em que opera a filosofia crítica, no nível do sujeito. A mudança para um ponto onde essa realização se tornasse plena é a tarefa da exposição da Lógica hegeliana, que pelo motivo de expor a íntima relação do que é efetivo com o próprio pensamento acaba se convertendo em um pensamento que além de uma lógica, é também uma ontologia ${ }^{35}$.

\subsection{O princípio da filosofia}

A discussão sobre o início da filosofia, e portanto, o fundamento do pensar, diz respeito a saber se seu começo é mediato ou imediato. Segundo a exposição da lógica, a questão do princípio da filosofia cinde o aspecto formal do material, e assim, insere uma separação entre o princípio e o início. O princípio, a verdade, o que se investiga, inicialmente é o ponto objetivo, de alguma maneira determinado (Deus, ar, ideia, etc.). O início é o aspecto subjetivo, e de um ponto de vista ingênuo ${ }^{36}$, é apenas uma tomada de decisão arbitrária. $\mathrm{O}$ saber do princípio é abstrato, já que imediatamente ele é simplesmente o princípio. O direcionamento desse saber abstrato leva à questão sobre o saber em geral, sobre o aspecto subjetivo e formal que se tem das determinações desse princípio. Assim, da mera objetividade, passa-se a colocar o aspecto subjetivo e formal como parte constitutiva da verdade do princípio, e entender o método passa a ter a mesma relevância que entender o próprio princípio. No sistema pensado por Hegel

não existe nada nem no céu, nem na natureza ou no espírito ou seja lá onde for, que não contenha imediatamente a imediatidade bem como a mediação, de modo que essas duas determinações se mostram como inseparadas e inseparáveis e aquela oposição como algo nulo (HEGEL, 2011, p.50)

O resultado é o que vem a ser verdade, a verdade do princípio. Entretanto, essa mediação é de certa forma suspensa no princípio. Há uma dupla relação do início com a imediatidade e com a mediação. Se o início é mediado pelo que ele pressupõe anteriormente,

\footnotetext{
${ }^{35}$ Vale lembrar que Kant não chega a esse nível justamente por misturar o nível do pensamento puro com uma teoria do conhecimento, relacionando o pensamento aos objetos. (Cf. WERLE, 2014, p.191.)

${ }^{36}$ A denominação "ingênuo" é dada por Hegel às metafísicas clássicas. Hegel expõe o fato de que as simples determinações das coisas como dadas na nossa representação serviam de critério para a verdade, o que justificaria a alcunha de ingenuidade. A crítica da forma desse saber ainda não se fazia presente de forma marcante. A questão é analisada como um dos pontos de vista em relação à objetividade na pequena Lógica da Enciclopédia das Ciências Filosóficas, ponto que será abordado mais adiante.
} 
ele também nos é simplesmente dado, e o aceitamos como algo imediato. Pelo menos como o iniciar, ele é imediato. Assim, como algo imediato, é excluída dele qualquer relação com o outro, com qualquer forma de mediação. Essa imediatidade simples tira do início a natureza de "saber". Ele é simplesmente "ser", assim como na Lógica o puro saber não é saber de algo, mas simplesmente saber, um saber vazio de determinações.

A imediatidade é a exclusão da relação do início com suas ulteriores determinações e relações. Se algo inicia uma ciência, esse algo não pode encontrar uma justificação anterior a si, nem encontrar determinações em si mesmo, já que, caso houvesse alguma determinação, como início ele já teria algo de mediato, e por não conter nenhuma determinação, o início não contém verdade alguma.

O sistema de Hegel é como ele mesmo salienta, "um progredir como retroceder", no qual o pensamento gradualmente se direciona ao fundamento do imediato; ele retrocede àquilo que lhe dá sustentação e o fundamenta ${ }^{37}$. O sistema tem funcionamento circular, onde o "essencial para a ciência não é tanto que algo puramente imediato seja o início, mas que o todo da mesma seja um percurso circular [Kreislauf] em si mesmo, onde o primeiro também é o último e o último também é o primeiro" (HEGEL, 2011, p.54).

A progressão do saber é determinação do princípio a partir do início, mas ele permanece como um princípio imanente que irá permear todo o desenvolvimento da ciência em questão onde nada é descartado ou deixado de lado $^{38}$. E é nessa progressão do saber que o que é imediato no começo deixa de sê-lo para tornar-se mediado pelas determinações que ocorrem. Naturalmente o início deve ser absoluto, porém abstrato; ser, simplesmente. Todo saber se inicia com uma pressuposição que será ulteriormente desdobrada e analisada, e é essa análise que fornecerá os princípios e fundamentos do saber, a justificativa do princípio.

A conclusão dessa exposição sobre o início do pensar é que o início sem qualquer tipo de desenvolvimento é desprovido de conteúdo, e, portanto, não pode ser conhecido, mas

\footnotetext{
${ }^{37}$ Marcos Müller, ao analisar a negatividade do início do sistema na Lógica, observa que o estágio final do desenvolvimento do espírito é a exteriorização do puro ser, a universalização completa do Si. Assim, esse simples ser coincide com o início. "Esse começo é aqui apresentado como surgindo de uma mediação plena do espírito consigo mesmo, mediação que se suspende a si mesma, e, assim, suspende a própria pressuposição do puro saber enquanto resultado da Fenomenologia do Espírito" (MÜLLER, 2014, pg.71)

${ }^{38}$ A partir desse ponto é possível questionar uma interpretação muito corrente do pensamento de Hegel que a dialética é um superar, um simples progresso em direção a uma direção, como se as etapas anteriores fossem consideradas ultrapassadas e as novas figuras versões superiores das anteriores. O que vemos é um sistema circular, em que as determinações ulteriores na verdade fundamentam as anteriores de acordo com uma forma mais adequada ao conteúdo. Mas, em contrapartida, as figuras anteriores se veem justificadas e confirmadas nas posteriores. Não há acréscimo no conteúdo.
} 
somente pressuposto. Isso é significativo para a questão da religião que nos dedicaremos a pensar. Ora, o início como a pressuposição de que Deus é simplesmente não leva a conhecimento algum sobre o que Deus é, muito menos sobre o que é a sua verdade. O começo de toda ciência não é somente um puro nada, mas um começo que tende para o ser. $\mathrm{O}$ indeterminado se direciona a uma determinação, de forma que o princípio é um afastamento do não-ser, da vacuidade que sua posição imediata e abstrata o coloca. O gradual desenvolverse do pensamento é a supressão dessa oposição, um afastamento da negação inicial da abstração.

A explicação para tais posições de Hegel sobre a dinâmica e o desenvolver do início do pensar podem ser apontadas com a primeira parte da Ciência da Lógica, em que o desenvolvimento do primeiro ser imediato é tratado. O ser, inicialmente, é somente o conceito abstrato com qualquer determinação a ele retirada, uma vez que sendo o início, não deve conter mediações em si. É uma universalidade abstrata que encontramos no puro ser e em razão disso, todos os atributos que poderíamos atribuir a ele encontram-se fora como diferenças. O puro ser do início, caso fosse equivalente a alguma de suas qualidades, seria algo conhecido por meio dessa qualidade, comportando em si mesmo uma mediação.

Por este motivo, as determinações do ser devem aparecer como seu próprio desenvolvimento e não como algo aderido a ele exteriormente. A tarefa que Hegel se incumbe é mostrar que a contradição que o puro início comporta, engendra um movimento em que o próprio conceito inicial do ser se desenvolve e passa a compreender em si mesmo as suas qualidades e determinações. Assim, "essa determinação-progressiva é a um tempo, um porpara-fora e portanto um desdobrar-se do conceito em si essente; e, ao mesmo tempo, o adentrar-se em si do ser, um aprofundar-se do ser em si mesmo” (HEGEL, 1995, §84, p.173).

Essa progressão do simples se inicia com a relação imediata que existe entre o nada e o ser. Isso pode se depreender da afirmação de que o

ser, puro ser [...] em sua imediatidade indeterminada ele é apenas igual a si mesmo e não desigual diante do outro, não possui nenhuma diversidade no interior de si nem para o exterior [...] ele é a pura indeterminidade e o vazio (HEGEL, 2011, p.72)

O nada por sua vez, é também uma "igualdade pura consigo mesmo, vacuidade perfeita, ausência de determinação e de conteúdo; indistinção nele mesmo” (HEGEL, 2011, pp. 72 e 73). Poderíamos concluir que por definição ambos são a mesma coisa, sendo que um conceito não pode coexistir excluindo-se o outro; na verdade ambos só subsistem por serem oposições um ao outro. Entretanto, Hegel observa que a unidade indistinta de ambas não é 
algo imediato neles, ou seja, a unidade surge como um terceiro termo perante os dois termos opostos. Esse passar de um termo a outro é o devir, uma passagem de um termo a seu oposto, e essa passagem constitui o primeiro passo do movimento que engendrará toda a dinâmica do pensamento. Por este motivo insistimos no fato de que o inicio engendra um movimento no qual o que é exterior, e portanto, oposto, é internalizado ao mesmo tempo em que tais termos terminam por ser relacionados. Assim, as partes opostas em relação são expostas em sua necessidade. O movimento do devir é uma gradual internalização por parte do ser de suas diferenças, na qual ele mesmo deixa de ser um ser abstrato e se torna um ser determinado e em passagem por passagem, cada vez mais adequado ao seu conceito.

\section{$1.3 \mathrm{O}$ pensamento e a realidade - a Natureza.}

Desta forma, o natural não é algo simplesmente visto como inferior ou oposto ao espírito, mas sua parte constitutiva, que deve ser assimilada e tornada racional pela atividade racional. Essa concepção fica mais clara na exposição da Enciclopédia das Ciências Filosóficas, onde Hegel se detém, na primeira parte da seção intitulada "filosofia do espírito", a explicar o conceito de espírito, que é "a ideia efetiva que se sabe a si mesma" (HEGEL, 1995, p.15). Na linha que tentamos expor até aqui, vimos que a unificação não pode ocorrer somente idealmente, de maneira formal, mas deve ser uma unidade concreta e efetiva entre os opostos. O Ser unificado, abstrato e inicial, deve sair de si mesmo e voltar a se compreender através do movimento da reflexão que lhe relaciona com sua determinação. Assim, o absoluto se torna consciente de si mesmo através da consciência finita.

Desta maneira, chegar a própria consciência de si mesmo quanto espírito, envolve pôr a si próprio como objeto e reconhecer nessa oposição a si mesmo. A natureza é, portanto, o espírito que se aliena de sua própria identidade consigo, pois na natureza

\footnotetext{
manifesta-se a ideia no elemento do "fora-um-do-outro"; ela não é só exterior ao espírito, mas, porque é exterior a este, mas porque é exterior à interioridade, essente em si e para si, que constitui a essência do espírito, ela, justamente por isso, é exterior também a si mesma (HEGEL, 1995, p.16)
}

Essas palavras nos levam a crer que enquanto houver algo de exterior, ou seja, enquanto ainda houver alguma oposição que caracteriza a exterioridade, ainda não haverá a identidade do conceito, do racional, com a realidade que lhe corresponde. É provável também que devido às passagens serem graduais, o trajeto deste processo constitua uma história na 
qual as figuras encontram efetividade enquanto são a realização do espírito enquanto forma em determinado tempo. Essa história diz respeito ao grau de identidade que espírito de um tempo é capaz de realizar.

No mesmo adendo da Enciclopédia das Ciências Filosóficas que aludimos acima, o §381, Hegel mostra que em cada esfera da existência há um grau de superação da exterioridade. Isso se explica pelo fato de que se o espírito precisa se determinar e sua auto alienação se mostra na forma da natureza, isso quer dizer que o espírito se corporifica, tornase matéria, à qual deve ser compreendida como instante da ideia que se aliena no processo no qual o espírito retorna a si mesmo. É possível que por este motivo é que são elencadas "escalas" de ser, no qual o ápice encontra-se na subjetividade com o homem; no caso com a concepção de "Eu". Somente com o Eu é possível haver uma concepção de espírito, pois ele é "algo perfeitamente simples, universal. [...] O Mas o espírito não é esse ser abstratamente simples, igual à luz [...]: o espírito é antes, algo diferenciado em si mesmo, apesar de sua simplicidade" (HEGEL, 1995, p.19).

Chegando até esse ponto é possível que alguns confundam as intenções de Hegel identificando em sua filosofia uma tendência (ou uma constituição mesmo) panlogística, ou seja, de que a realidade de tudo se resume à lógica e que o pensamento abstrato consegue dar conta da compreensão e da estruturação do mundo real. É necessário compreender o papel e o lugar da lógica no sistema para tentar evitar esse tipo de compreensão, como bem alerta Bernard Bourgeois:

O problema do lugar - do estatuto e do papel - da lógica no sistema enciclopédico
de Hegel envolve o da significação geral do hegelianismo: a questão de saber se este
é um panlogismo foi, de fato, uma questão recorrente. [...] Certamente, no
hegelianismo, a especulação une o objeto e o sujeito, o conteúdo e a forma, o sabido
e o saber, mas o saber do sabido constitui um outro sabido. [...] Assim, o saber pleno
ou total do lógico, que é a lógica, só é possível na medida em que ele se faz resultar
da integração, nele, dos momentos mais concretos do absoluto (a natureza e depois o
espírito) (2004, p.301)

Assim, temos que o fundamento do sistema e do real como um todo é a Ciência da Lógica, ciência do pensamento em seu elemento puro. Entretanto, a Lógica comporta o pensamento em seu elemento abstrato, puro, já depurado das etapas em que se enveredava na dicotomia sujeito/objeto. O lógico é a verdade do conceito, constituindo uma perfeita harmonia dentro de si mesmo.

Na medida em que o acabamento do sistema como pensamento puro é a própria lógica, impõe-se que o ser, o passo inicial da lógica, só poder realmente ser sem contradição 
alguma (lembrando que imediatamente o ser é nada) quando se recolhe ao elemento puro do pensar. Dessa maneira, o ser, já identificado com o pensar, é uma livre manifestação sendo afirmação de si mesmo. Isso implica que: o pensar é uma manifestação de si próprio no elemento puro da ideia. "A ideia é então, independentemente dessa objetividade, pura e simplesmente simples e imaterial, pois a exterioridade é apenas como determinada pelo conceito e acolhida em sua unidade negativa" (HEGEL, 2011, p.236).

A ideia por ser totalidade simples deve ser a verdade do que é material e contraditório (cujo movimento do conceito é sua negação), pois compele essa subsistência exterior das coisas a si, ao pensamento. Se é assim, a própria ideia subsiste como totalidade na medida em que ela se exterioriza a si mesma e se faz outro, pois a alteridade é parte constitutiva de sua natureza. Dessa maneira, o que se chama realidade (em oposição ao "abstrato") nada mais é que a ideia em sua alienação de si mesma. Em outras palavras: é a ideia considerada como exterioridade, na qual é o transitório e o que não é verdadeiro e livre em si e para si.

Se a ideia, portanto, tem logo sua realidade em uma materialização, então essa não é um ser abstrato, que subsiste por si mesmo contra o conceito, mas apenas como devir, por meio da negatividade do ser indiferente como determinidade simples do conceito (HEGEL, 2011, p.236)

E dessa concepção de que a ideia se exterioriza chegamos à concepção do que é a natureza e a objetividade no sistema hegeliano.

Visto que a ideia é assim como o negativo dela mesma ou exterior a si, assim a natureza não é exterior apenas relativamente ante essa ideia (e ante a existência subjetiva da mesma, o espírito), mas a exterioridade constitui a determinação, na qual ela está como natureza (HEGEL, 1997, §247, p.26)

A exposição da lógica como fundamento do sistema nos permite compreender o que significa a exterioridade para Hegel, pois em seu sistema o objetivo, ou seja, a natureza, é a forma com a qual a ideia se manifesta inicialmente como alteridade. Disso resulta que o natural é caracterizado como tudo que é exterior. De acordo com o que temos mostrado, exterioridade nada mais é que tudo aquilo que se mostra de maneira contingente e eivada de contradição, fazendo com que não seja efetiva por si mesma.

A natureza por ser alteridade é a negação da ideia, mas mesmo assim, é referida a ela, sendo assim determinada como algo exterior. Dessa maneira, ela é "a contradição não resolvida" (HEGEL, 1997, §248, p.30). A lógica em si só é fechada como um ciclo, mas ir para fora de si mesmo em sua própria negação engendra um domínio em que o oposto dela é posto. Sendo o oposto da ideia, esse domínio é o domínio do sensível e do empírico, sendo 
que o conceito permanece como algo oposto a ela, somente um interior (subjetivo). Faltando esse elemento interior da ideia à natureza, e consequentemente, ausente a característica de sujeito nela, lhe resta somente a característica de um ser-posto, como algo puramente objetivo e negativo (por manter seus conteúdos como partes isoladas umas das outras). Essa forma de relação das partes na natureza é um ser posto no espaço e no tempo, uma vez que essas são as formas primeiras e imediatas da natureza (o tempo, nesse caso, é a negação do espaço). Dessa forma, em uma relação natural, as coisas se encontram simultaneamente em um lugar em eventos que ocorrer de maneira sucessiva ${ }^{39}$. Assim,

\begin{abstract}
a divisibilidade infinita da matéria significa apenas que ela é um algo exterior a si mesmo; a imensurabilidade da natureza, que antes de tudo causa espanto ao sentido, é justamente a sobredita exterioridade. Porque cada ponto material parece perfeitamente independente de todos os outros, por isso a falta-de-conceitos [Begrifflosigkeit] domina na natureza, que não coaduna seus pensamentos (HEGEL, 1997, §248, p.31)
\end{abstract}

Sobre as formas imediatas do natural: "a determinação primeira ou imediata da natureza é a abstrata universalidade de seu ser-fora-de-si, a equivalência dele sem mediação, o espaço" (HEGEL, 1997, §254, p.47). Ainda sobre o mesmo tema: "O tempo é como o espaço uma pura forma da sensibilidade ou do intuir, é o sensível insensível [...] é o mesmo [princípio] ou o simples conceito ainda em sua total exterioridade e abstração" (HEGEL, $\S 258$, p.54 e 55).

Nesse domínio da exterioridade, do fora-um-do-outro, resta um amontoado de relações contingentes entre as partes, já que cada elemento subsiste por si só, mas sem conseguirem, por isso, serem determinados por eles mesmos. Ao mesmo tempo falta a essa relação contingente a marca da liberdade do sujeito, e por esse motivo as relações da natureza são relações que se determinam por causas e efeitos. O conceito é a verdadeira necessidade, mas a necessidade interna que revela a liberdade de não ser determinado por algo exterior a si mesmo. Por esse motivo a necessidade da liberdade é o oposto da relação causal que impera na natureza, já que os efeitos nunca se confundem com suas causas (mantém uma relação exterior como dois termos distintos).

Essa autocontradição do elemento exterior à natureza a conduz para um estágio no qual a ideia finalmente deve se compreender como razão, como subjetividade. Segundo

\footnotetext{
${ }^{39}$ Para os presentes propósitos, não nos cabe aprofundar a definição e a evolução dos conceitos de tempo e espaço em Hegel. Porém, a indicação de que as formas naturais primeiras são o espaço e o tempo são muito importantes para o posterior estudo da representação nos capítulos posteriores, razão pela qual entendemos ser importante fazer essa menção aqui. Mais acerca disso surgirá na questão da representação na religião no último capítulo.
} 
Vittorio Hösle, a dinâmica do movimento da natureza tem o propósito de mostrar essa ideia, que é somente em si, cada vez mais como auto consciência, superando a alteridade característica das relações naturais. "Este tem a tarefa de pôr a ideia que age na natureza como aquilo que ela é em si, isto é, manifestá-la cada vez mais expressamente" (HÖSLE, 2007, p.323). Essa manifestação da ideia é a aparição dela para si mesma, da subjetividade e do conceito como forças propulsoras e auto referentes.

Tanto que o ponto culminante da filosofia da natureza é a superação dessa alteridade, revelando-se como espírito. Assim, o espírito é a realização do conceito que vem a ser para si, superando a alteridade com seu objeto que caracteriza a relação natural.

O conceito deseja romper a casca da exterioridade e vir-a-ser-para-si. A vida é o conceito exposto, mas para o entendimento simultaneamente o mais difícil de apreender, pois para o abstrato, morto - enquanto que é o mais simples -, é o mais fácil de apreender (HEGEL, 1997, §251, adendo, p.39)

1.4 Conclusão - o Espírito como superação da natureza.

No espírito a subjetividade finalmente se compreende como um movimento necessário de interiorização do que está relacionado de forma independente a si mesmo. Finalmente é possível entender a citação de Hegel acerca da essência do espírito que fizemos no início desse capítulo. Surgindo como movimento de superação da alteridade da natureza, o espírito tem em seu início a pressuposição da superação da natureza, ou seja, a subjetividade já a assimilou a si. "Como tínhamos dito, o espírito nega a exterioridade da natureza, assimila a si a natureza, e por isso a idealiza” (HEGEL, 1995, §381, adendo. p. 21).

Idealizar aqui tem o sentido especulativo de fazer a exterioridade ser negada como tal, revelando-se o seu ser posto pelo pensamento. Ao negar o objetivo o espírito perpassa essa exterioridade e a transforma em algo posto por si. Assim, quando o pensamento penetra em todas as múltiplas faculdades e forças que existem no mundo natural como potências autônomas, ele as liga, sintetiza, pois sua oposição e correlação independente são só partes de uma só atividade, que é a subjetividade do pensamento. "Essa suprassunção da exterioridade suprassunção que pertence ao conceito do espírito - é o que temos chamado sua idealidade." (HEGEL, 1995, §381, adendo. p. 18). 
Esse fato explica porque Hegel disse no referido parágrafo 381 que o espírito é negatividade absoluta, pois a atividade do pensar nada mais é que negar a exterioridade como tal e posicioná-la como algo posto pela atividade do pensar. O conceito é essa atividade subjetiva, na qual tanto o sujeito quanto o objeto se equiparam.

Afirmando que "todas as atividades do espírito nada são a não ser maneiras diversas da recondução do que é exterior, à interioridade que é o espírito mesmo; e só mediante essa recondução, mediante essa idealização ou assimilação do exterior, vem a ser, e é, o espírito" (HEGEL, 1995, §381, pp. 18 e 19), entendemos que a atividade do espírito não é somente a recondução do exterior à unidade subjetiva, mas também o pensamento é a própria objetivação nessa idealização, fazendo com que a atividade do pensamento seja uma via de mão dupla. Não só a exterioridade se interioriza, mas este se torna objetivo, uma vez que ele é a efetividade de fato. Esse é o significado da idealização e da superação da natureza operada pela subjetividade ao superar a natureza e se fazer espírito. Assim, "a essência do espírito é, por esse motivo, formalmente a liberdade, a absoluta negatividade do conceito enquanto identidade consigo" (HEGEL, 1995, §382, adendo. p. 23).

Podemos finalmente afirmar que o espírito é o estágio no qual as relações exteriores foram superadas, mas não no sentido de serem postas de lado, mas sim no sentido de que foram acolhidas do interior do pensamento. Isso é importante na medida em que os estágios do desenvolvimento do espírito não são um simples abandonar etapas anteriores de sua determinação, mas entendê-las como momentos constitutivos de sua natureza. E isso é compreensível se levarmos em conta que, quando o espírito vem a ser a partir da natureza, o que se põe é o conceito como sujeito e como objeto posto. Ele é a totalidade, de forma que se compreende que em tudo o que existe é o espírito que já está presente. Se considerarmos que o espírito é uma marcha para a frente na qual o que antecede um grau determinado é simplesmente superado, estaríamos presos numa forma de pensar relativa às relações naturais, nas quais as etapas e figuras do que existe são tidas como existências independentes que não dependem de seus opostos para serem determinadas como são ${ }^{40}$.

\footnotetext{
${ }^{40}$ Nesse sentido, Dirk Stederoth: "a "morte da natureza" não significa que a natureza, e, com isso, a corporeidade não desempenhasse nenhum papel para o espirito, que ela poderia estar extinta para o espírito. Pelo contrário, o espírito faz da natureza sua condição, a qual, no entanto, ele deve incorporar a si. [...] O desenvolvimento do espírito através de seus vários graus - espírito subjetivo, objetivo e absoluto - é, portanto, nada mais que um processo de libertação das dependências naturais, e isso em um duplo aspecto: primeiro como incorporar da natureza respectivamente do mundo no espírito, e ao mesmo tempo na forma de um incorporar do espírito no mundo, o que se efetua, entre outros, no direito e na eticidade" (STEDEROTH, 2010, p.33)
} 
As determinações e os graus do espírito são essencialmente só como momentos, estados, determinações nos graus superiores do desenvolvimento. Por isso ocorre que numa determinação inferior, mais abstrata, o [que é] superior se mostre já empiricamente presente, ao passo que, por exemplo, na sensação todo o espiritual mais elevado [está presente] como conteúdo ou determinidade (HEGEL, 1995, $\S 380$, p.14)

Assim, a realização da Lógica de Hegel nesses moldes envolve um retorno a si mesmo a partir dessa exteriorização que ele realiza na natureza, e assim é espírito. A superação do natural é a consciência de que o pensamento é sujeito e também objeto, que a objetividade é ser posto pelo pensamento. Esse ciclo que engloba o pensamento puro que se exterioriza e retorna a si mesmo é o todo do sistema hegeliano, cuja exposição é chamada de "Enciclopédia", não por ser uma compilação de saberes diversos e sem relação interior entre si, mas por apresentar o ciclo do pensamento em si mesmo. O todo do sistema comporta três partes: A Lógica, a filosofia da natureza e a filosofia do espírito, sendo que essa parte corresponde, no campo da realidade, ao ponto culminante do sistema. Esse trajeto é o trajeto que o pensamento percorre para fazer com que o que é inicialmente universal, mas subjetivo, o conceito, acolher o exterior e fazê-lo idêntico a si. Já discutimos antes o fato de que não basta que algo seja em si, mas deve ser também para si. Ao pensamento não basta que seja somente o todo; mas como pensamento, também deve ser consciente de sê-lo. Ser em si e para si também.

O espírito, que é o estágio no qual o exterior da natureza é referido ao pensamento, não surge imediatamente como algo já completo e acabado. Pelo argumento do parágrafo anterior, o que é efetivo é o pensamento que retorna do imediato exterior a si mesmo. Portanto, o espírito que vem a ser a partir do natural é espírito somente imediatamente, e por isso, é abstrato em um estágio inicial. É necessário que o espírito saiba a si mesmo como totalidade. Hegel esclarece essa questão:

O espírito, portanto, começa somente de seu próprio ser, e só se refere a suas próprias determinações. [...] Agora, é só isto que tem a fazer: realizar esse conceito de sua liberdade, isso é, somente suprassumir a forma da imediatez com que ele começa de novo (1995, §440, pp.210 e 211)

O que podemos depreender desse trecho é que o trajeto do espírito até sua realização plena é um depurar de forma, pois o conteúdo é o próprio conceito. Portanto, a dialética do espírito é uma realização do conceito através da elevação da forma a outras que comportem cada vez menos exterioridade, ou em outros termos, que consiga expor as diferentes determinações como relacionadas entre si pelo pensamento. 
Assim, o espírito inicialmente é espírito finito, pois mesmo que seja imediatamente a certeza indeterminada de ser a síntese do subjetivo com o objetivo, ainda falta ao espírito saber a si mesmo como tal, o que implica em conferir a forma do espírito ao que lhe é contraposto, ao objetivo. Segundo Hegel, "falta-lhe, assim, ainda aqui, o conhecimento determinado da racionalidade do objeto" (HEGEL, 1995, §441 adendo, p.213). Ou seja: no espírito imediato ele se sabe síntese do objetivo e do subjetivo, mas ainda lhe aparecem as figuras da subjetividade e da objetividade em oposição. Falta ao espírito compreender como essa objetividade é expressão sua e não algo simplesmente oriundo do exterior. O objeto, em si racional, ainda mantém a forma da exterioridade, forma essa que deve ser elevada à interioridade do conceito.

Esse espírito finito, por assim sê-lo, é contraditório, pois o espírito deve ser a totalidade, a realização de seu conceito. Por isso ele mantém em si o movimento dialético que movimenta a ideia e progride a formas que melhor possam exprimir a unidade do conceito com a efetividade. "O progredir do espírito é desenvolvimento" (HEGEL, 1995, §442, p.214). A depuração formal que o espírito realiza ao racionalizar o objeto nada mais é que um retorno a si, um fazer-se consciente da própria racionalidade nos seus objetos.

Enquanto o espírito não atinge a consciência de ser ele mesmo a totalidade ele é espírito finito. No sistema de Hegel da enciclopédia o espírito é dividido em espírito subjetivo, espírito objetivo (que correspondem às duas etapas do desenvolvimento do espírito finito) e finalmente o espírito absoluto. "Fato estranho [...] é que a filosofia do espírito absoluto, na qual culmina, afinal, o sistema de Hegel, recebe na Enciclopédia um tratamento dos mais típicos de madrasta" (HÖSLE, 2007, p.641). De fato, a parte destinada ao esclarecimento do desenvolvimento do espírito absoluto na enciclopédia é extremamente exíguo, o que levou o comentador Vittorio Hösle a proferir o comentário citado acima.

Todavia, se o desenvolvimento não foi realizado na Enciclopédia, por outro lado ele foi largamente desenvolvido e explorado nas preleções que Hegel proferiu em Berlim, que segundo o mesmo Hösle, "juntamente com as preleções sobre a filosofia da História, constituem na edição da Associação de amigos quase a metade da obra de Hegel, em volume" (HÖSLE, 2007, p.641). Uma das partes desse desenvolvimento do espírito absoluto é justamente a filosofia religião que passaremos em análise a partir de agora. 


\title{
CAPÍTULO II: A RELIGIÃO NOS MANUSCRITOS DE 1821.
}

\subsection{Apresentação e relação dos manuscritos com a Enciclopédia das Ciências Filosóficas:}

Tendo esclarecido o que é o espírito em linhas gerais, agora temos ferramentas para compreender o conteúdo das exposições de Hegel acerca da religião. Na própria Enciclopédia há uma parte destinada ao tratamento da religião, muito embora ele seja bastante enxuto e carente de grandes detalhamentos. É digna de atenção uma definição presente no $§ 565$ que é o fundamento de nossa atual exposição, que é a seguinte:

\begin{abstract}
O espírito absoluto, tendo suprassumido a imediatez e a sensibilidade da figura e do saber, é, segundo o conteúdo, o espírito essente em si da natureza e do espírito; segundo a forma, é antes de tudo para o saber subjetivo da representação. Esta, de um lado, dá autonomia aos momentos do conteúdo do espírito absoluto, e faz deles pressuposições, uns para com os outros, e fenômenos que se seguem uns aos outros, e uma conexão do acontecer segundo as determinações finitas da reflexão. De outro lado, tal forma de modo-de-representação finito é também suprassumida na fé no único espírito, e na devoção do culto (HEGEL, 1995, §565, pp. 347 e 348)
\end{abstract}

O esclarecimento do conteúdo desse parágrafo é a explicação do próprio papel e natureza da religião segundo a interpretação que Hegel lhe confere a partir do ponto de vista do desenvolvimento sistemático de sua filosofia. Como nosso propósito é analisar esse desenvolvimento realizado nas preleções de Berlim, passaremos agora a analisar como as explicações de Hegel em 1821 conseguem dar conta desses conceitos expostos no texto da Enciclopédia.

A estrutura da exposição do conceito de religião nos manuscritos ${ }^{41}$ segue uma divisão em quatro partes, que são: a) o conceito de religião em geral, b) O conceito científico do

\footnotetext{
${ }^{41}$ A exposição dos manuscritos de 1821 segue uma descrição desse desenvolvimento religioso a partir de uma abordagem empírica das religiões, a partir da qual Hegel mostra a necessidade do conceito especulativo da religião. Concordam com essa posição dois comentadores da filosofia da religião de Hegel: Albert Chapelle e Peter Hodgson. O Primeiro diz o seguinte: "assim, o pensamento deve primeiro abordar a representação histórica imediata da religião, uma via bem geral, mas também bem precisa para manifestar globalmente a estrutura conceitual" (CHAPELLE, 1963, p.193). Já para o segundo, o conceito de religião só se firmou no decorrer das preleções, sendo que em 1824, por exemplo, a exposição já contém uma comparação do ponto de vista especulativo com o ordinário da consciência, de forma mais clara. Segundo ele, "as preleções de 1821 abordam a definição por via indireta através de uma descrição da religião tirada da experiência empírica. [...] Os elementos principais já estão presentes, mas são apresentados confusamente" (HODGSON, P. 2005, p. 78). Essa divisão foi proposta por Walter Jaeschke que a reafirma no "Hegel Handbuch" (Cf. JASCHKE, 2003, p.458).
} 
ponto de vista religioso, c) a necessidade desse ponto de vista e d) a relação da religião com a arte e a filosofia.

O cotejo com as disposições da Enciclopédia se faz importante pelas questões abordadas no capítulo anterior, ou seja: as preleções têm de dar conta dos aspectos especulativos apresentados na Enciclopédia e na Ciência da Lógica para ter coerência com o sistema. Essa correlação é defendida por Albert Chapelle, que na sua análise do conceito de religião também segue a linha expositiva de Hegel. Ele defende que

esse texto [...] nos parece, em sua redação final, responder perfeitamente às
exigências dialéticas do método especulativo, aquele que nos foi revelado nas
páginas precedentes, na Introdução à Lógica da Enciclopédia. Temos percebido a
necessidade de alguma transposição do texto para assegurar ou a coerência ou a
autenticidade hegeliana (1963, p. 193)

A relação das lições de Berlim com o resto da filosofia de Hegel é um tema bastante polêmico, já que pode surgir a dúvida no leitor sobre qual parte é mais relevante: se a parte que foi efetivamente publicada ou as lições que tem um conteúdo mais específico. A linha que seguimos no presente texto adota a posição tanto de Chapelle quanto de Walter Jaeschke, para quem "os capítulos da religião nas três versões da Enciclopédia pertencem ao mesmo estágio de desenvolvimento que as preleções" $(1986, \text { p.221 })^{42}$. Isso quer dizer que os textos são abordados de forma sistemática, razão pela qual nossa opção por expor o funcionamento do sistema no primeiro capítulo desse texto.

Seguindo o raciocínio de Jaeschke, há poucas divergências entre as três versões da Enciclopédia, e isso não reduz a autoridade das lições, já que a seção destinada à religião na Enciclopédia é muito curta. Essa "economia" de explicações, por assim dizer, faz com que esse conteúdo seja pouco ou minimamente afetado pelo desenvolvimento subsequente do sistema em suas partes. Segundo ele, sobre as preleções e sobre os manuscritos "eles são também indispensáveis para a exploração do texto da Enciclopédia. [...] Grande parte dos problemas não podem ser resolvidos na forma apresentada na Enciclopédia, sequer serem formulados" (1986, p.222).

O que está em jogo, na verdade, é "desafiar a pretensa superioridade da versão da Enciclopédia e enfatizar a indispensabilidade das preleções" (JAESCHKE, 1986, p.223). Vale observar, ademais, que na parte destinada à religião na Enciclopédia trata-se somente da 
religião revelada ${ }^{43}$, ou seja: do cristianismo. Isso ocorre porque, mesmo de acordo com a exposição das preleções, o cristianismo é a realização da religião enquanto representação do absoluto. A compreensão dessa posição surgirá ao término do presente texto. Por enquanto, basta saber que seguiremos nossa exposição de acordo os passos dados por Hegel em seus manuscritos, a fim de acompanhar e comentar cada etapa de sua argumentação. A verdadeira fundamentação filosófica da questão da religião é abordada de fato na segunda seção, quando trata da necessidade interna do conceito de religião e sua definição especulativa. Na primeira parte, intitulada o conceito de religião em geral, Hegel parte da religião como percebida pelo senso comum, e, a partir da representação religiosa, aponta algumas contradições em suas posições, funcionando como uma espécie de parte introdutória para o tema propriamente abordado de forma filosófica. Nesta primeira parte, entretanto, Hegel já defende algumas posições com base em argumentos que serão aprofundados somente no decorrer das explicações, como na parte em que critica a fé como único acesso ao absoluto. Por este motivo, em determinadas partes optamos por deslocar a exposição de alguns temas para outras, a fim de que a linha argumentativa fique mais clara. A última etapa da exposição do conceito diz respeito à caracterização da religião como representação, e será objeto do próximo capítulo.

\subsection{O Conceito de Religião em Geral:}

O início da exposição de Hegel contém, logo de pronto, uma definição inicial de religião ${ }^{44}$ com a qual ele começa a desenvolver o assunto que é a definição da religião como

a consciência de Deus em geral, quer seja na forma do sentimento, representação, cognição, conceito, conhecimento, ou qualquer outra possível. Mas o objeto que estamos a considerar é a própria religião, e imediatamente a encontramos nestes dois

\footnotetext{
${ }^{43}$ Em relação a esse assunto, citamos a passagem na qual Vittorio Hösle disserta sobre o tema: "a filosofia hegeliana da religião [...] tem de ser tematizada como parte de uma teologia filosófica; nela é tematizado Deus na medida em que ele se realiza na religião - e, de fato, em todas as religiões e não somente no cristianismo, mesmo que em maior proporção neste." (HÖSLE, 2007, p.696.)

${ }^{44}$ Consideramos importante fazer a seguinte observação: as preleções de Berlim, sejam da filosofia da religião ou de outro assunto como Arte ou História, seguem o esquema aqui proposto, ou seja: inicia-se a exposição a partir da definição (conceito) do objeto tratado. O sistema, segundo sua estrutura lógica apresentada na Enciclopédia ( $\$ 575$ a 577), pode apresentar três formas de silogismos, que seguem um movimento próprio de acordo com o tipo de mediação que apresentam. Com o sistema tripartido em três partes principais, temos a) Lógica; b) Natureza e c) Espírito. Essa ordem também pode se apresentar como: a) Natureza, b)Espírito e c) Lógica, ou ainda a) Espírito, b)Lógica e c) Natureza. A Enciclopédia por apresentar o todo em sua forma especulativa tem uma forma de apresentação diferente da presente (Lógico, Natural e Espiritual) nas preleções, mesmo a dos manuscritos. Para mais detalhes sobre essa distinção, ver (Cf.DIAZ, J. Hegel y La Religion.)
} 
momentos: (a) o objeto que está na religião e (b) consciência, o sujeito, o ser humano que se coloca em direção a este objeto, sensibilidade religiosa, intuição, etc. (1993, p.95)

O que depreendemos logo de início com essa afirmação, e que se confirmará conforme Hegel avança em sua explicação ${ }^{45}$, é que a religião surge a partir do momento em que se abandona uma concepção unilateral que se tem a respeito de Deus, ou seja, como uma pura substância oposta ao sujeito. A consideração a respeito de Deus em seu ser desconsiderando o aspecto da subjetivo do crente é uma posição metafísica explorada ao longo da tradição, cuja posição foi atacada na modernidade e especificamente na filosofia crítica, como vimos. Essa ciência do ser de Deus era chamada de "theologia naturalis", ou teologia natural, e consistia na exploração dos atributos divinos.

Exploramos longamente no capítulo anterior a virada promovida pela filosofia em relação a sua consideração com a objetividade. A aceitação de um ser exterior ao pensamento dotado de atributos é o mesmo que aceitar pacificamente a existência de algo sem a crítica dos conceitos nele envolvidos, e sem levar em conta a contradição que decorre de se pensar um ser pleno e perfeito sem contradições. A concepção de espírito de Hegel é contrária a essa substância estática cheia de atributos que são adicionados a essa substância como partes isoladas.

Hegel faz questão de lembrar que "O conceito de Deus é a ideia de Deus, nomeadamente, tornar-se e fazer-se objetivo para si mesmo. Isso está contido em Deus como espírito" (1993, p.96). Se Deus é espírito, está envolvido em sua atividade espiritual, como vimos anteriormente, fazer com que se torne consciente de si mesmo como espírito, o que nesse caso implica que Deus deve fazer-se consciente de sua divindade. A consideração de Deus não pode, portanto, prescindir de considerar a manifestação dele mesmo em uma consciência, e é por isso que Deus só pode existir em sua comunidade, no seio de um grupo humano que tem consciência de Deus como sua totalidade. "Deus é essencialmente em sua comunidade e tem uma comunidade" (1993, p. 96). É nessa medida que a consideração sobre o conceito de Deus conduz necessariamente para a religião, que é o que confere determinação a essa ideia divina. Segundo o comentador britânico de Hegel, Peter Hodgson, "O conceito de

\footnotetext{
${ }^{45}$ Conforme indicamos anteriormente, a forma de exposição do tema da religião sofreu modificações na medida em que Hegel ia aperfeiçoando e lapidando o tema de suas aulas. Nas preleções, de 1827, por exemplo, as lições já se iniciam com o conceito especulativo de Deus, o que aparece nos manuscritos de 1821 somente implicitamente no meio do texto, mesmo porque a linha seguida na exposição é diferente de uma preleção para outra.
} 
religião é essencialmente o conceito de Deus, ou Deus e a humanidade juntos e essa união é o que Hegel chama de "espírito"” (2005, p.77).

A religião, assim, nos oferece sempre uma relação dúplice: a) o lado de um objeto, que é Deus, cujo conceito desenvolvido, pelas razões acima conduzem para o segundo aspecto, que é o b) o lado subjetivo, ou o lado da consciência que tem esse Deus por conteúdo. Albert Chapelle nos recorda que "em sua acepção mais geral, a religião aparece primeiramente como consciência de Deus. E revela imediatamente dois momentos: o objeto e o sujeito da religião" (1963, p.194).

De fato, a religião não é um terreno simples da consideração sobre a natureza divina como se revela na teologia natural, já que em toda religião está em jogo uma consciência que se relaciona com essa divindade que se forma como essência de todas as coisas. "Ela é antes a teoria especulativa que conhece Deus como o Espírito que se comunica e se manifesta na consciência de si da comunidade na qual se torna objeto de consciência" (CHAPELLE, 1963, p.194). Essa dimensão subjetiva que envolve a ação dos crentes em relação a essa divindade foi chamada outrora de teologia moral, ou dos deveres dos homens a partir de sua imagem de Deus.

Bem, se a ideia é o todo e ela já se faz presente em todos os estágios do desenvolvimento de sua exteriorização, é compreensível que Hegel afirme que "se agora essa definição de Deus não estiver ainda presente na consciência de uma comunidade, ela está [mesmo assim] presente em si e para si (e está presente em toda religião)" (1993, p.97). Isso quer dizer que por mais que uma determinada crença não possua de forma clara para si mesma a ideia especulativa de Deus, isso é, que ele necessariamente se faz vivo na consciência de uma comunidade e se revela a si mesmo através dela, essa ideia já está presente implicitamente em todas as religiões. Isso se deve ao fato de que "Deus é essencialmente algo que é representado, conhecido, intuído, etc., é encontrado no sentimento de reverência, gratidão, etc.," (HEGEL, 1993, p.97) fazendo com que a noção especulativa da revelação de Deus esteja presente nas religiões de forma ainda não desenvolvida.

O desenvolvimento dessa autoconsciência divina depende, do que se depreende dessas páginas iniciais de Hegel, do nível de desenvolvimento do aspecto subjetivo da religião, que é 
o ponto para o qual ele passa diretamente logo após expor a ideia de que a noção especulativa de Deus já está presente em todas as religiões ${ }^{46}$.

O aspecto mais imediato das religiões é que há um lado oposto ao outro, como vimos. A divindade aparece para o sujeito primeiramente como algo totalmente diferente dele, como uma potência infinita adiante. Diante dessa potência está um sujeito que subsiste por si só, possuidor de vontade e pensamentos. Entretanto, essa potência não é somente um objeto qualquer, mas Deus mesmo, o que indica que ele é também a essência do próprio sujeito. Dessa forma o sujeito que está diante dessa divindade se enxerga como algo totalmente transitório e evanescente, já que ele é algo totalmente fraco e impotente diante desse grande poder divino. Ainda assim esse Deus é imediatamente a própria essência do sujeito; ele é sua substância, sua essência e não a essência de algo estranho a ele ${ }^{47}$.

Essa relação conduz, portanto, a um impasse que apresenta duas naturezas: inicialmente ela é negativa: somente Deus é. A consciência que reconhece a potência divina é algo ínfimo e evanescente (nesse caso temos a afirmação do positivo em detrimento da subjetividade), ou somente o lado finito existe (o que nos leva ao ateísmo, à afirmação da subjetividade e a negação do positivo).

A finitude é relacionada ou negativamente a Deus ou afirmativamente a si mesma [...] A Finitude tenta ligar esse fosso na forma do conhecimento reflexivo, que aparece filosoficamente como entendimento e religiosamente como representação, mas nesse ponto de vista o infinito permanece um além incompreensível ou uma simples projeção do finito (HODGSON, 2007, p.78 e 79)

Contudo, essa relação também é positiva: essa potência não é uma essência estranha, mas sim a essência do próprio sujeito que crê. Dessa forma, a religião também comporta uma unificação. Por um lado, ela é consciência da separação infinita entre o finito e o infinito, entre o próprio homem e Deus todo poderoso. Por outro, ela avança em direção a uma superação dessa oposição, pois reconhece nessa potência superior a si mesmo. "O sujeito é implicitamente idêntico [com a essência absoluta], a qual é sua substância, seu sujeito, que

\footnotetext{
${ }^{46}$ Essa ideia de Hegel está fundamentada em sua metafísica, o que conduz, por seu movimento, ao cristianismo como religião que realiza esse ideal especulativo. Esse ponto será analisado mais adiante quando alcançarmos o ponto de discutir a realização do conceito de religião.

${ }^{47}$ A ideia de essência é uma parte principal da estrutura da Ciência da Lógica, cuja definição encontramos com as seguintes palavras: "A essência está entre o ser e o conceito e constitui o centro dos mesmos e seu movimento o constitui a passagem do ser para o conceito. A essência é o ser-em-si-e-para-si, mas o mesmo na determinação do ser-em-si; pois sua determinação é provir do ser ou ser a primeira negação do ser." (HEGEL, 2011, p.105 e 106.) Ao referir essa relação entre o homem e Deus a noções conceituais da essência, Hegel indica já que a religião é uma passagem entre o ser imediato do homem para um status mais elevado, negando-se, portanto, na religião, a imediatez na consideração do homem sobre si mesmo, sobre sua natureza finita e individual. Esse aspecto fica claro nas diversas passagens nas quais Hegel diz que na religião o homem abandona seu ser finito e sua existência cotidiana para algo maior e infinito.
} 
está no sujeito, é sua essência, não a essência de um outro" (HEGEL, 1993, p.98). Essa relação positiva em relação a essa essência se manifesta como sentimento de pertença a uma totalidade, a uma participação nessa unidade em atos que podem ser mais ou menos internos ou exteriores aos indivíduos, e a essa parte da religião Hegel chamou de "culto".

Assim, para Hegel, o culto é uma parte essencial do conceito de religião, pois ele determina a forma como Deus é relacionado à humanidade. Segundo ele, "enquanto o conceito de Deus, em termos de determinidade que possui em cada estágio, é necessariamente também a determinidade dessa relação com Deus" (HEGEL, 1993, pp.98 e 99). Os dogmas religiosos nada mais são um conjunto de regras prescritas a seus fiéis de como alcançar a salvação, de como agir para se elevarem ao plano da razão divina.

Dessa maneira, são apresentados para nós através desse texto do manuscrito, dois aspectos do conceito de religião: um aspecto objetivo e um aspecto subjetivo, conforme raciocínio de Chapelle que também apresentamos aqui anteriormente. De acordo com o francês, "A primeira determinação objetiva, tomada isoladamente, foi o tema metafísico da "theologia naturalis". A religião, contudo, não se reduz a uma teoria sobre Deus” (1963, p.194).

E assim somos conduzidos para o aspecto subjetivo da religião, que é a consciência do crente em Deus. Já havíamos feito menção a isso quando citamos os dois aspectos da religião no início desse capítulo. O que restava a ser dito é que a consciência desse Deus implica um determinado modo de agir, de forma que a representação de Deus é intimamente ligada ao culto que é feito a essa divindade. Dessa forma, a representação de Deus é inseparável de seu culto, assim como determinado culto é indissociável de uma representação determinada de uma divindade.

Hegel é enfático sobre essa matéria. Vale a pena seguir o curto parágrafo no qual essa relação é feita:

O aspecto subjetivo e cultico da religião é, assim, o outro elemento essencial na consideração da religião em geral. Devemos considerar a base no qual as características dos dois correspondem uns aos outros - a forma e o conteúdo do conceito de Deus, e a relação para com Deus; uma é cópia da outra, da qual devemos aprender a compreender a outra (1993, p.99)

Esse é um aspecto capital na teoria da religião de Hegel, pois graças a essa concepção é possível estabelecer uma crítica à religião como fé como vinha se apresentando até então em seu tempo como uma tendência, assim como vimos na introdução a esse texto. $O$ 
aprofundamento dessa questão, contudo, faremos mais adiante na ocasião do tratamento do conceito especulativo da religião, pois Hegel critica a posição da fé em seu tempo com base em conceitos que só serão expostos nessa seção. Ainda a respeito do culto, ele é a ação efetiva da religião, a verdadeira superação dos termos cindidos, o objetivo e o subjetivo.

O culto é o serviço religioso que efetiva a consciência do crente como termo médio entre a representação de Deus (o lógico, pelo conceito) e o espiritual, a consciência de si mesmo a partir do outro. Essa também é a posição de Charles Taylor quando afirma que "é a dimensão do culto que faz a religião transcender a simples consciência. É o culto que realiza a unidade ou restaura a unidade entre espírito finito e espírito infinito" $(2014 \text {, p.521) })^{4849}$

Nesse mesmo sentido nos explica Jorge Díaz que na religião

se trata de descobrir em cada um dos termos opostos [...] a insuficiência que os caracteriza e a necessidade de se integrar a seu outro, para, desse modo, compreenderem que provém de uma unidade originária que se faz real e se manifesta quando se desdobra neles para chegar a ser ela mesma (p.225, tradução nossa)

2.3 A concepção científica da religião.

Nessa seção é apresentado por Hegel o desdobramento da representação inicial da religião. A surge da dicotomia interno/externo, e por essa razão, é um desdobramento que parte de um ponto de vista reflexivo (a dinâmica segue adiante a partir da contraposição dos opostos neles mesmo e em sua superação). Essa posição é sustentada por Marcelo Aquino, para quem "antes de tudo, é preciso não se deixar enganar por esse subtítulo, como se já se tratasse do conceito especulativo de religião. Antes, pelo contrário, a necessidade desdobrada agora é a elaborada pela representação" (AQUINO, 1989, p.206).

\footnotetext{
${ }^{48}$ Como práxis humana que promove a unidade da finitude com o universal do conceito, seria de se esperar que a religião fosse a verdadeira realização da Sittlichkeit. Entretanto, essa identificação só ocorria no mundo antigo. Para o homem moderno o culto não é mais o culto de um povo determinado, mas transcende os limites de uma língua e leis particulares de um Estado. O papel da religião é relativizado na era moderna pelo Estado racional e suas instituições, sendo que ao religioso compete o aspecto da formação e da unidade interior dos homens com o absoluto. A concretização dessa união, de fato compete às instituições públicas. E é por isso que Hegel se opôs a um Estado confessional, embora entendesse que o estado deveria ser tolerante com a liberdade religiosa. Sobre esse tema, Hegel se prolonga no $\$ 270$ da Filosofia do Direito e em uma das únicas partes restantes das preleções sobre a filosofia da religião de 1831, que trata da relação da religião com o Estado.

$4949 \mathrm{O}$ aspecto positivo e constitutivo do culto na religião pode ser deduzido das palavras de Cristo a São Pedro, no Evangelho de Mateus: "Também eu te digo que tu és Pedro, e sobre esta pedra edificarei minha igreja, e as portas do inferno não prevalecerão sobre ela. Eu te darei as chaves do reino dos céus. E tudo que ligares sobre a terra, será ligado também nos céus.” (Mt, 16, 18,19).
} 
Apesar dessa observação, o propósito aqui parece não se desviar do que foi proposto desde o início das preleções. O início do discurso é do da representação comum da religião, que mostra a necessidade do conceito especulativo. A presente seção do texto elabora justamente uma crítica à necessidade externa da religião para uma consideração de sua necessidade interna, de acordo com a realização de seu conceito. Essa parte do texto pode ser dividida em três temas principais: a) que trata de negar a religião como necessidade externa, b) do conceito especulativo da religião e c) sobre a necessidade do ponto de vista religioso.

2.3.1 - A distinção entre a necessidade externa e interna.

Hegel explica que o ponto de vista científico da religião "significa nada mais que a exposição da necessidade da posição religiosa" (1993, p.108). Contudo, deve-se explicar que essa necessidade deve ser a necessidade do conceito, uma necessidade interna ao próprio desenvolvimento do sistema, que em sua própria dinâmica necessariamente chega à religião como seu momento inafastável de realização.

Por isso é importante afastar a ideia de que a religião é necessária por servir a determinados interesses, o que faria dela um simples meio para se atingir algum fim, sendo assim contingente. Isso poderia significar que a religião é necessária para fazer um homem ser bom ou mesmo para que ele seja feliz. Outros podem dizer que a religião é primordial para fazer cumprir o elemento ético dentro de determinado Estado. Em ambos os casos a religião é útil para se atingir um fim pretendido por um indivíduo, por governos ou estados. Sendo útil para algo ela é meramente um meio para se atingir determinado fim.

O problema de se colocar algo como meramente útil para algo é colocá-lo sob o viés da contingência, pois um meio pode ser utilizado ou não. $O$ indivíduo pode usar a religião para ser feliz assim como pode se valer de outros meios, assim como um governo pode educar seu povo pela religião ou pelo modelo republicano de escola, por exemplo. E sendo um meio dentre vários, a religião torna-se descartável.

É claro que se a religião deve ser mostrada como manifestação específica do espírito absoluto, Hegel não pode lançar mão de expor a questão sob o ponto de vista de uma necessidade meramente exterior. O que deve ser exposto é a própria necessidade da religião 
na realização do propósito do espirito de se revelar a si próprio, de abolir a distância entre o pensamento e a exterioridade.

\subsubsection{O Conceito Especulativo de Religião}

O conceito especulativo da religião é o de ser a consciência da verdade em si e para si, tal qual a filosofia. Esta última, por sua vez, é a consciência da ideia, fazendo com que tudo seja exposto conforme ela. A ideia, como vimos no primeiro capítulo, é a verdade expressa no puro pensar, o ponto máximo do sistema hegeliano exposto segundo a Ciência da Lógica. Portanto, a verdade da filosofia não é expressa como intuição, tampouco como representação.

Vimos anteriormente, que a verdade na ideia é a que consegue conciliar os opostos, e por isso é chamada de especulativa. O todo é intuído e representado, ao passo que a reflexão marca as distinções e coloca determinações nesse todo. Tais distinções permanecem opostas e permanecem uma ao lado da outra, já que a simples reflexão, por si só, não avança além disso. A unidade que subjaz a essas determinações é entendida como um instante distinto delas, e é visto como algo exterior. É como se não fossem parte do mesmo por si só. O especulativo do filosofar é justamente entender os objetos em sua unidade no pensamento, tanto do natural quanto do espiritual. "Essa é a verdade como verdade, como unidade do que é diferenciado" (HEGEL, 1993, p.114).

A religião, desta maneira, é a consciência dessa verdade, mas não de qualquer uma, como um objeto ordinário. Nela se apresenta a verdade que tem ser em si e para si mesma, que se põe a si própria. Essa unidade suprema, contudo, só existe na ideia, e é por esse motivo que Deus tomado somente como uma substância separada do finito é só uma abstração.

A religião, portanto, é a consciência do verdadeiro em si e para si, é consciência da verdade como universal que perpassa todas as coisas, fora da qual não permanece nada, tal como a filosofia. Sua especificidade é manifestar essa verdade na forma da representação e não da ideia. Enquanto o finito precisa de uma determinação exterior a ele mesmo, a verdade tem sua própria determinação, seu próprio limite e seu próprio fim nela mesma, de forma que o outro é encontrado dentro dela própria. É essa especulação que surge para a consciência religiosa. Essa plena verdade, contudo, só se alcança completamente na filosofia. Ela está 
implícita na religião, mas somente "nós" a percebemos, como uma observação pensante [denkende betrachtung].

Assim, para a religião, "seu objeto e tudo mais existe na mais concreta forma da representação: Deus e comunidade, o culto, absoluta objetividade e absoluta subjetividade" (HEGEL, 1993, p.115). Assim, inicialmente, em seu momento abstrato, esse conceito da religião como saber da verdade apresenta dois instantes, aqueles que foram expostos no conceito geral da religião: o aspecto objetivo e o subjetivo. Em termos especulativos expressamos esses aspectos como a absoluta universalidade e a absoluta singularidade.

2.3.3 - A Relação religiosa como unidade da absoluta universalidade e da absoluta singularidade.

A religião, sendo consciência da verdade em si e para si, como demonstrado em seu conceito especulativo, se opõe à percepção sensível, à intuição e às verdades finitas. O especulativo é justamente o que se coloca além dessas limitações. Por esse motivo, a verdade no nível da religião é uma verdade que tem natureza universal.

Assim sendo, o religioso é uma passagem de um estado para outro. Em outras palavras, poderíamos dizer que na religião o homem em sua natureza de ser consciência finita, se eleva ao infinito de sua essência, isso é, Deus. Esta definição é fundamental para compreendermos o papel da religião no funcionamento do sistema. Sobre esse ponto Hegel diz que a religião "é uma elevação, um erguer-se acima, um refletir sobre, uma passagem além do que é imediato, sensível, singular (já que o imediato é o que é primeiro e consequentemente não elevação)" (1993, p.116).

A ideia de passagem diz respeito ao conteúdo do $\$ 566$ da Enciclopédia que trata da separação da forma e do conteúdo e de sua reconciliação. Reproduzimos aqui o curto parágrafo integralmente:

Nesse separar, a forma se divide do conteúdo; e, na forma, os diferentes momentos do conceito se dividem em esferas particulares ou elementos particulares, em cada um dos quais o conteúdo absoluto se expõe: $1^{\circ}$ enquanto conteúdo eterno, que permanece junto de si em sua manifestação; $2^{\circ}$ enquanto diferenciação entre a essência eterna e sua manifestação, que por essa diferença se torna o mundo fenomenal no qual entra o conteúdo; $3^{\circ}$ enquanto infinito retorno e reconciliação do mundo extrusado, com a essência eterna; o retornar, da mesma essência, do fenômeno para a unidade de sua plenitude (1995, §566, p.348) 
Esse parágrafo resume toda a dinâmica apresentada nas preleções sobre a passagem, pois ela se direciona na direção do elemento " 3 ”" do $§ 566$ : o culto religioso é o retorno da ideia abstrata inicial (Deus) para si mesmo através de sua comunidade (o finito).

Sobre essa questão da passagem, é importante lembrar o modo de desenvolvimento do espírito que nos referimos no capítulo anterior. O desenvolvimento das etapas descritas pela filosofia do espírito nada mais são que níveis nos quais o pensamento gradualmente se mostra, para si mesmo, como o fundamento da objetividade. Assim, o avançar nada mais é que um retroceder ao fundamento. As passagens não são, portanto, um sair de si para um outro qualquer, mas para um outro que é o si mesmo exteriorizado.

É importante salientar este aspecto para entender que a passagem que Hegel faz menção no caso da religião não é um sair para um outro como um terceiro, em uma progressão infinita. Essa característica do espírito impede uma progressão sem fim, já que a elevação ao segundo termo da relação é também um avanço/retroceder ao próprio fundamento. "Este é o processo do espírito em geral, e desde que imediatamente posto, isso é absolutamente universal, consequentemente essa atividade é pensamento, e esse universal ilimitado, Deus, é o mais alto pensamento" (HEGEL, 1993, p.116 e 117). Sobre a questão do pensar, também é importante não esquecer que no nível da religião o pensamento não é tratado como teórico, mas também como ação. ${ }^{50}$ Por isso temos, além da representação de Deus, os atos do culto.

Sobre esse ponto fica claro perceber que a religião só pode pertencer ao domínio do pensamento, mesmo em suas etapas mais abstratas. Deus só pode ser concebido pelo pensar, e é isso o fundamento basilar de toda forma de religião, que Hegel chamou de "devoção" $[\text { Andacht }]^{51}$. A devoção é esse pensamento basilar que funda a religião é não contém ainda as determinações ulteriores que a reflexão produz no objeto. Ela não avança além dessa pura afirmação inicial. "Na religião o dilaceramento entre intelecção e a fé é superado de tal modo que o espírito como religião tem imediatamente sua consciência de si própria, pura, se sabe a

\footnotetext{
50 “O pensamento é intrinsecamente atividade, o que significa que o pensamento como tal é atividade, não pensamento como subjetividade. (HEGEL, 1993, p. 117).

${ }^{51}$ Taylor entende que como na consciência religiosa não é possível ter uma visão clara sobre a relação da finitude com o absoluto (isto cabe à filosofia), essa união intrínseca é apresentada como devoção [Andacht]. A devoção é a base de toda a religião, o ponto de partida que é a relação/unificação inicial do subjetivo com o objetivo (Cf. TAYLOR, 2014, pp.520-521).
} 
si mesmo de modo imediato como espírito, ele tem certeza de ser espírito" (VIEWEG, 2007, p.16). ${ }^{52}$

Essa devoção inicial é apenas o pensamento em seu nível mais abstrato, e portanto, não é o nem sentimento [Gefühl] nem sensibilidade [Empfindung $]^{53}$. A sensibilidade, que no caso da religião seria uma espécie de sensibilidade devota, não pode ser encarada como a mesma coisa, já que qualquer determinação no estágio abstrato inicial já comportaria uma espécie de "avançar" em relação ao estágio inicial, e assim já é uma determinação.

O que Hegel quer chamar a atenção para a devoção é o fato da religião, mesmo nas mais elementares formas, sempre ser um terreno do pensamento, por mais que se defenda seu aspecto sensível, esse lado do sentimento da crença. O sentimento na religião não é uma pura crença em nada, mas é um sentimento que sempre busca determinar seu objeto de adoração. Sobre esse aspecto, trataremos mais adiante ${ }^{54}$.

Por ora basta dizer que a devoção é o estágio inicial e imediato da religião, e que ainda não comporta uma diferenciação; é pensamento simples, sem qualquer desenvolvimento no sentido de determinação ou conteúdo. A religião, entretanto, é uma relação de dois lados. De um temos a absoluta universalidade do puro pensar, do outro a absoluta singularidade da existência contingente. A religião opera justamente a relação entre esses dois aspectos do pensamento: "Eu como sujeito pensante, e eu como sujeito imediato, somos um ao mesmo tempo" (HEGEL, 1993, p.119) ${ }^{55}$. Os dois lados são presentes para o pensamento na religião. No habitar o pensamento de Deus, o pensamento se eleva ao incondicionado, mas ao mesmo

\footnotetext{
${ }^{52} \mathrm{O}$ que está em questão aqui é que a contradição dessa unificação inicial se desenvolve até a confirmação subjetiva abandonar a forma da pura interioridade e se tornar conceito, ideia absoluta. Para tanto essa unificação deve passar pelo crivo da reflexão, o que culminará, como veremos, no abandono da representação para a forma do conceito.

${ }^{53}$ Essa distinção é muito importante nesse nível e marca bem as diferenças entre os manuscritos de 1821 e as demais preleções posteriores. Na maior parte do texto dos manuscritos, Hegel usa mais o termo Empfindung. Posteriormente, contudo, usa mais o temos Gefühl. As anotações de aula do curso de 1824 marcam bem essa mudança. É possível, como aponta Peter Hodgson (HEGEL, 2007, p.209) que essa mudança na preferência de Hegel tenha se dado pelo fato de que a partir de 1821 o termo Gefühl tenha ganhado relevância na questão religiosa a partir do texto de Schleiermacher intitulado "Der Christian Glaube" (A fé cristã), onde exalta o sentimento do infinito como forma acabada da religiosidade. O mesmo autor sublinha que o uso de Empfindung no texto de 1821 se de como contraponto a Jacobi. Em ambos os casos, a crítica ao saber imediato tem o mesmo fundamento, sendo que a diferença nos termos indica, por probabilidade, qual o alvo que mais "preocupava" Hegel na elaboração do conteúdo do curso.

${ }^{54}$ É uma das críticas à concepção da religião como sentimento, vazio de determinação. Tratamos desse tema no fim desse capítulo.

${ }^{55}$ A diferença, poderíamos dizer, é que na filosofia, já no elemento do pensamento, a cisão é superada por ambos os opostos estarem no campo do pensamento, fazendo essa transição de uma maneira diferente. Na religião a oposição é superada elevando-se o finito ao nível da universalidade, mas jamais como pensamento: algum nível de objetividade ainda persiste nela. Esse é o objeto do próximo capítulo, quando trataremos desse tema com mais cuidado.
} 
tempo se sabe esse ser finito. A religião é a própria consciência desse conflito e dessa oposição postas em relação no crente. Pode-se tanto afirmar a existência finita em oposição ao infinito quanto esquecer a si próprio e se deixar envolver pela potência infinita de Deus, sua substância. O meio termo dessa oposição é justamente esse transitar entre os dois opostos. $\mathrm{Ou}$ seja: na consciência religiosa os dois opostos são conectados; "eu sou o conflito, já que o conflito é justamente este embate, que não é indiferença dos dois como distintos, mas seu manter-se junto" (HEGEL, 1993, p.121). As formas como se relacionam esses opostos caracterizam as formas da religião.

Inicialmente, a relação não é ainda de um pensamento consciente, portador de um objeto pensado, como vimos na imediatez da devoção. Mas a devoção imediatamente conduz para uma determinação posterior que é a sensibilidade religiosa. E Hegel chama esse estágio de sensibilidade porque o pensamento se coloca diante desse "percebido" como algo totalmente exterior, como algo percebido imediatamente. Segundo a estrutura da Lógica apresentada no capítulo anterior, o imediato é justamente o que aparece como totalmente exterior, na qual a sensibilidade é a consciência de ser algo apartado dos objetos que percebe. Ou seja: eu tenho consciência de mim mesmo como permanente diante do fluxo do devir dos objetos que percebo.

A intuição e a representação são os estágios posteriores a essa percepção inicial da sensibilidade, nos quais essas contingencias são apartadas do que "é meu", daquilo que é percebido e interiorizado, em dois momentos, segundo Hegel: “(1) Eu tenho essa determinação em mim, (2) e ela não sou eu" (1993, p.123). Assim, a imediatez inicial é suspensa, já que o objeto agora passa a ser mediado pela ação do pensamento ${ }^{56}$. Esse trajeto é o direcionamento natural do imediato para a representação. "O conflito mesmo me direciona além da sensibilidade para a representação" (HEGEL, 1993, p.124).

Daí em diante a sensibilidade inicial caminha para determinações do que é intuído. O caminho natural, seguindo a dinâmica do conceito apresentada no primeiro capítulo, é do indeterminado e abstrato caminhar, por suas próprias contradições para o que é mais determinado. Por esse motivo o desenvolvimento natural dessa condição inicial da

\footnotetext{
${ }^{56}$ Isso se dá justamente pelo fato de que perceber que sou algo subjetivo frente a um objeto, na verdade constitui o elemento inicial da universalidade. A oposição constitui já em si uma unidade, a saber: eu só sou subjetivo como oposto a esse objeto contraposto a mim. Esse pensamento é já por si só uma ligação, na qual os dois opostos são unificados como parte da mesma relação. Quando a subjetividade intui e representa o objeto ela o distingue de si, mas ao mesmo tempo sabe que essa é a sua própria atividade. O pensar é que perpassa as determinações. Esse movimento é o mesmo apontado na lógica acerca do pensamento que penetra os opostos e faz deles parte de seu desenvolvimento.
} 
sensibilidade religiosa é caminhar para a representação, que aqui nada mais é que atividade da reflexão que produz a distinção entre o sujeito e o objeto.

Consciência como tal (como distinta da auto consciência) tem em princípio um objeto externo. (...) Intuição tem sua externalidade em sua natureza totalmente objetiva, na forma da espacialidade e temporalidade; na representação como tal o objeto simultaneamente é posto em mim (HEGEL, 1993, p.126)

Segundo a natureza espiritual do homem, mencionada antes como puro pensar, a consciência humana naturalmente é representativa, na medida em que confere determinações e separa o subjetivo do objetivo. Para Hegel, "não há sensibilidade que não seja também representação" (1993, p.126), já que a sensibilidade naturalmente acaba por promover a diferenciação do que é percebido e de mim mesmo em relação a ela.

O objeto da religião é o absolutamente universal, e por esse motivo a sensibilidade da religião carrega em si a própria contradição e o conflito, já que sentindo meu objeto como pura objetividade é o mesmo que anular a mim mesmo nesse processo (levando em conta que esse objeto é a essência de todas as coisas). Na medida em que é o próprio eu que sente essa força que o anula, ele sente a angústia e o sofrimento dessa separação, esse sentir-se negado e acolhido ao mesmo tempo. Como oposição o sentimento inicial naturalmente se torna uma representação, pela razão exposta acima ${ }^{57}$.

Trata-se se perceber, com a presente exposição do conceito especulativo, que na religião já se começa a superar a noção inicial que temos de que as faculdades são absolutamente separadas e independentes umas das outras. No decorrer desse capítulo da exposição do conceito de religião, Hegel mostrou o que decorre de se perceber a representação sem a sensibilidade, que é o caso da teologia natural, onde se concebe uma divindade sem levar em conta a subjetividade que a sente. Esse Deus é não espiritual, pois lhe falta justamente a capacidade de se fazer efetivo no mundo através dos atos de seus devotos. O oposto também é verdadeiro e é exposto por Hegel ao término da exposição do conceito especulativo.

A sensibilidade sem representação não tem um objeto determinado que a sustenta. Sem a representação a sensibilidade não existe. Sem que se determine o que se ama, o amor desaparece. Se um inimigo é odiado mas não se sabe quem é o inimigo, o ódio desaparece. Da mesma forma, a religião necessita da doutrina e da determinação trazida pela representação,

\footnotetext{
${ }^{57}$ Aqui a natureza da representação está ligada à capacidade de separar e manter uma determinação em relação com o oposto. Sobre a questão da representação, avançaremos no próximo capítulo.
} 
caso contrário decai na inércia e no vazio. "Precisamente na medida em que a religião é vista como sendo puramente no modo da sensibilidade, a religião morre em algo vazio de representação e ação e perde todo conteúdo determinado" (HEGEL, 1993, p.128).

Essa questão envolve justamente a questão da fé que será novamente abordada posteriormente quando Hegel tratar especificamente da representação. Ao término dessa exposição, faremos um adendo apontando brevemente alguns pontos acerca da questão da fé.

2.3.4 - A necessidade desse ponto de vista ${ }^{58}$.

Como visto antes, a necessidade externa não pode dar conta da espiritualidade da religião, já que conceber a religião como meio para se alcançar um fim faz com que ela se torne algo contingente. Nessa parte do texto, Hegel retoma a discussão dos parágrafos anteriores, como uma retomada. "O exórdio desse tratado esclarece somente o caráter esquemático do mesmo. A primeira unidade literária retoma o discurso com a problemática anterior" (AQUINO, 1989, p.211). Contudo, neste trecho Hegel trata da questão da prova da religião, e isso relaciona-se com a questão de sua própria verdade/necessidade.

A afirmação de que a religião é a expressão da riqueza do universo comporta uma verdade (a verdade pelo seu aspecto objetivo é Deus). Já o aspecto subjetivo é a própria religiosidade como a afirmação da própria consciência de si. A prova é justamente a terceira parte que citamos acima, é o relacionar de ambos. A prova da religião é o conhecimento da verdade. E Hegel não entende a ideia da maneira usual, mas sim como um movimento que mostra a necessidade interna do conceito. A necessidade interna é o surgimento de um objeto pelo próprio movimento imanente do pensamento, e não uma finalidade exterior a si mesma. Assim, expor a necessidade interna de algo é o mesmo que provar a sua existência;

\footnotetext{
${ }^{58}$ Walter Jaeschke, realizador da edição crítica, aponta para diversas lacunas e problemas nos manuscritos de 1821 que só seriam sanados nas preleções seguintes. Sobre essa seção, por exemplo, é importante notar que Hegel não deu a ela um desenvolvimento que desse conta realmente da questão da prova da necessidade do conceito de religião. Segundo Jaeschke "é claro desde a primeira sentença que a necessidade não pode ser "tratada aqui em detalhe". A única ocupação é entende-la e seu procedimento" (JAESCHKE, 1986, p.234, tradução nossa). A razão desse "corte" temático é que "demonstrar a necessidade envolveria abordar novamente "o todo da esfera das ciências filosóficas"” (JAESCHKE, 1986, p.234, tradução nossa). Exatamente por esse motivo, quando tratamos aqui da questão da prova, fazemos menção a outras obras de Hegel, já que ele foi bem econômico em explicações a esse respeito nos manuscritos.
} 
demonstrar que algo se justifica justamente por ser resultado de um movimento do próprio pensamento em sua efetivação.

A explicação de como funciona a questão da prova/necessidade, é um tópico que não diz respeito à filosofia da religião, mas à lógica, como bem lembrou Hegel na ocasião de suas lições sobre a prova da existência de Deus de $1829 .{ }^{59}$ Isso reforça o fato de que as preleções funcionam como um complemento e uma ampliação do que foi apresentado na Enciclopédia, a estrutura geral do sistema.

A prova em sua formulação tradicional é a utilizada nas ciências empíricas e é um "apontar" causas e efeitos e dar definições. Hodgson afirma que

a prova subjetiva, alega Hegel, tem lugar na região do conhecimento finito. É encontrada na geometria e na prova algébrica, onde a atividade continua totalmente em nós, em um tipo de prova que implica um "indicar" ou apontar coisas que tem lugar na experiência, passada e presente (2011, pp.06 e 07)

Essa visão é ratificada por Hegel nos manuscritos, especificamente na sessão que tratamos agora. Hegel afirma que a prova "não é questão de provar tais proposições como "Deus é isso" ou "a religião é isso e aquilo"” (HEGEL, 1993, p.131). Por isso, trata-se de o conteúdo mostra-se a si mesmo como verdadeiro. A verdade de algo, contudo, é sua ideia. E a ideia contem sempre em si dois aspectos: os dois lados em relação e a sua unidade. A verdade, portanto, só surge quando dois lados em oposição conseguem superar sua unilateralidade com a concepção do pensamento que as perpassa e as traz em sua unidade. Isso é o elemento especulativo. Essa posição também é defendida por Chapelle: “também a prova especulativa da verdade religiosa e de sua necessidade não consiste em atribuir mais ou menos justamente esse ou aquele predicado à representação pressuposta de Deus ou da religião” (1963, p.205).

\footnotetext{
${ }^{59}$ Hegel proferiu lições sobre este tema de 4 de maio a 21 de agosto de 1829 , em aulas semanais por dezesseis semanas. $\mathrm{O}$ curso foi ministrado paralelamente às lições sobre a lógica, o que se sobressai nos temas das provas, intimamente ligados à questões da Ciência da Lógica. Sabe-se também, que ele tinha até assinado um contrato com os editores Duncker\&Humbolt para a publicação de uma obra chamada "Über das Dasein Gottes", mas morreu alguns dias depois, não tendo realizado a obra. Sobre esse curso ministrado em 1829, restaram fragmentos de manuscritos, usados por Marheineke como apêndice para as lições da filosofia da religião na preparação da edição das obras de Hegel após sua morte. Contudo, a versão disponível hoje não é a dos manuscritos, mas de uma versão transcrita do original. Sobre essa versão, Jaeschke apresenta um editorial crítico presente na "Vorlesungesmanuskripte I"I (Hamburg: Felix Meiner Verlag, 1995). A versão consultada aqui é a inglesa publicada pela Oxford: (Lectures on the Proof of Existence Of God, Edited and Translated by Peter Hodgson, 2011). A citação referida aqui está presenta na primeira lição, e diz o seguinte: "Desde que nossa tarefa é, contudo, considerar as provas da existência de Deus, surge que somente um aspecto deste tópico pertence à lógica, nomeadamente a natureza da prova, enquanto o outro aspecto, o conteúdo do que é Deus, pertence à outra esfera, que é a da religião e sua consideração racional, a filosofia da religião." (HEGEL, 2011, p.37).
} 
Para se compreender toda a argumentação presente no tópico das preleções que estamos considerando, temos que levar em conta vários aspectos das passagens presentes na Enciclopédia e na Ciência da Lógica. Um deles, é claro, é nosso objeto de análise, a noção de prova, que está ligada, com exposto nas próprias preleções, à ideia de que provar algo é conhecer sua necessidade. Bem, a necessidade é uma questão tratada na Ciência da Lógica na parte destinada ao juízo da necessidade.

Já no tratamento da questão do pensamento e do conceito proposta no capítulo anterior, o juízo aparecia como forma do pensamento ${ }^{60}$, no qual opostos são relacionados. A necessidade na Enciclopédia das Ciências Filosóficas é tratada justamente como um juízo qualitativo, cuja definição é proposta no $\$ 177$, e diz que ele é "identidade do conteúdo com sua diferença".

Nos juízos, o predicado contém a essência ou a natureza do sujeito, tal como "o corpo é extenso". O ser do "corpo" é o ser "extenso". Esse tipo de juízo é chamado de categórico, pois esse predicado confere uma característica única e imutável para o sujeito ${ }^{61}$. Contudo, nesse tipo de juízo, ainda não há a conjugação completa dos opostos, pois a universalidade do predicado não se conjuga necessariamente à particularidade do sujeito. Isso quer dizer que para a extensão, não importa que estejamos falando de um corpo ou se um carro, uma cadeira, um homem, pois é igualmente necessário, para todos esses sujeitos, que são extensos. Dessa forma, condiciona-se essa correlação à participação de um particular a um gênero universal, ou seja: se o particular pertence ao gênero tal, logo é verdade a proposição. Essa passagem é dita por Hegel como a passagem do juízo categórico para o hipotético.

Finalmente, o juízo necessário, chamado disjuntivo, é o que resulta destas duas passagens. O juízo hipotético (se A, então B), possibilita que se diga que A é B, C ou D, e assim por diante. Isso quer dizer que o universal se expressa por suas inúmeras particularidades, ao mesmo passo em que o conjunto de particularidades é a expressão do

\footnotetext{
${ }^{60}$ Tal como citado por Hegel os manuscritos: "Consciência significa que eu sou, que eu tenho julgamento finito [grifo nosso]"(HEGEL, 1993, p.132).

${ }^{61}$ Nem todo juízo com essa formulação é categórico. Ele só se caracteriza como tal se a relação proposta for uma relação substancial, ou seja, que o predicado exprima uma característica que, se suprimida, suprime o próprio sujeito como tal. O exemplo dado de "corpo" diz que suprimida a extensão não temos mais o corpo. Seria diferente se se dissesse que o corpo é azul, pois é acidental em um corpo que tenha essa ou aquela cor. Sobre essa distinção, ver a explicação de Hegel no adendo ao referido §177 na Enciclopédia das Ciências Filosóficas.
} 
universal. Exemplo: o corpo é pesado e extenso; Deus é imortal e eterno. Fazendo esse movimento, o universal do predicado é igualado ao particular do sujeito, e, portanto, consegue expressar a necessidade de ambos, já que alcançam sua verdade na demonstração de sua mútua relação.

Esse trajeto aparece de forma implícita na exposição de Hegel acerca da relação da prova com a necessidade. A questão lógica não é aprofundada, mas é interessante observar que a relação existe justamente na medida em que é dito que na filosofia da religião trata-se de elevar o finito ao infinito. Nesse caso, quando elevamos um termo ao outro de uma relação, perfazemos o mesmo trajeto do juízo necessário, pois de um lado da religião temos Deus e do outro a consciência subjetiva da divindade. A passagem de um termo a outro é a demonstração da necessidade mútua de ambos os relacionados. Dessa forma, a prova de Deus é a própria religião, uma vez que, segundo mostramos antes, a própria religião é essa ligação, esse relacionar dos dois aspectos; provar algo, portanto, sempre passa por um movimento a partir do outro, já que a ideia surge do confronto de algo com sua determinação. É por isso que Hegel salienta que a "necessidade é derivação de algo outro" (1993, p.132), pois a necessidade é um vir a ser do pensamento que efetua a identidade do conteúdo com seu oposto.

$\mathrm{O}$ argumento das preleções mostra como a consciência suprime com sua reflexão a independência do objeto posto diante dela. Sua independência inicial se contrapõe à percepção de seu movimento e à inamovibilidade da consciência que o percebe. A consciência apreende desse objeto o que é de permanente, universal, presente nela. Assim, na religião, temos o infinito de Deus e a multifacetada riqueza do mundo finito. Como nossa consciência é um suspender da finitude (pelo processo especulativo), a necessidade do mundo finito na consciência é suspender a própria limitação e sua finitude. E esta suspensão ocorre em duas etapas. Na primeira, mo elemento da ideia, a finitude do mundo é suspensa, já que no ideal temos a conjugação da natureza e do espírito. E essa oposição do mundo finito é um dos lados opostos a Deus. Assim, como duplo aspecto do lado finito oposto a Deus, elas devem superar sua oposição em si mesmas para se igualarem com o infinito e incondicionado (Deus é a verdade). A verdade da natureza, como vimos antes, aparece quando ela se entende espírito, que estava nela implicitamente. E no estágio em que se mostra a verdade do natural como o espírito, é exposto o conceito objetivamente, que antes estava somente de maneira implícita. Essa é a primeira etapa da superação. 
A segunda diz respeito à própria superação da finitude no próprio espírito. Nesse estágio o espírito aparece para si como objeto, pois ele é consciente de ser a verdade da natureza como espírito, ou seja: que aparece na natureza. Assim, O espírito tem seu ser como a razão que perpassa a natureza, mas essa verdade aparece para ele mesmo inicialmente como algo imediato. O espírito deve ser o ideal, mas nessa fase ele ainda não é a ideia. Por isso ele comporta dois lados: o que ele é para si mesmo, ou seja, a parte ideal e fechada em si mesmo, e a finitude que é a consciência dessa verdade. Na medida em que existe o lado finito, naturalmente existe uma relação entre os lados. O que é em si e para si infinito não existe como tal para a consciência do espírito. Ele não se compreende como tal.

O desenvolvimento dessa relação é necessário do ponto de vista religioso. Aliás, a própria necessidade dessa elevação é a necessidade da própria religião, o relacionar e elevar os opostos à igualdade. Mantidos em sua oposição original, é possível ter uma visão do mundo e da consciência finita, mas postos dessa maneira não são equivalentes à representação de Deus, e é por esse motivo que o aspecto finito, que compreende o espírito finito e a si mesmo como objeto, devem superar sua oposição em si próprios para acompanharem a maneira como representam para si a verdade, isso é, Deus.

Dessa forma, "a necessidade é que essa riqueza deve imergir a si mesma nessa verdade" (HEGEL, 1993, p.140). E essa verdade é a representação de Deus. Mas essa verdade, como ideia, é uma manifestar-se e desenvolver-se; ela sai de si mesma e se manifesta no mundo, na própria riqueza que deve se elevar à divindade, como um movimento dúplice.

\footnotetext{
Mas, além, esses dois tipos de material - o auto desenvolvimento interno de Deus e o desenvolvimento do universo - não são tão absolutamente diferentes. [...] Mas estas essas esferas - a atividade da vida divina - são as mesmas que a vida do mundo. A vida do mundo, contudo, é somente aparência ao passo que a vida divina é eterna. Assim a vida do mundo aparece na vida divina na forma eterna (HEGEL, 1993, p.141)
}

Como Deus é a representação da verdade, a consciência da verdade de forma imutável, e ele é paralelamente a verdade do mundo, ele expressa a consciência de si deste universo de forma eterna. Daí a importância de se compreender, no âmbito da religião, o que é a representação no sistema. Pois como característica principal da religião ela marca a posição dessa figura em relação ao desenvolvimento do espírito em seu movimento de 
autoconsciência. Além disso, em tal estágio voltamos à definição apresentada no começo desse capítulo da Enciclopédia que tratava do conceito da religião. A exposição do conceito de religião expõe o que é a religião e seus momentos. Entretanto, assim como no texto enciclopédico, tais partes não podem ainda dar conta de explicar o funcionamento dessa passagem de um extremo a outro pela subjetividade. Isso porque falta, nessa exposição, o tratamento da representação ${ }^{62}$. Esse é o tema de nosso próximo capítulo. Resta ainda tratar, de forma breve, a questão da fé e do saber imediato na religião.

\section{$2.4 \mathrm{O}$ problema da fé.}

A questão da fé como manifestação última da religião, ou mesmo como a única forma possível de se chegar ao absoluto, é uma questão muito presente nos tempos de Hegel em decorrência do próprio desenvolvimento do pensamento de sua época, como tentamos explorar na introdução desse estudo.

Em um texto de 1802 chamado "Fé e Saber", Hegel aponta as filosofias de Kant, Jacobi e Fichte como pensamentos que acabam isolando o absoluto como algo inalcançável, apesar de suas diferentes formulações. Nessa época, os temas expostos no período sistemático estão ainda em forma germinal, já que ainda faltava aos textos de Hegel as formulações do sistema completo.

Poderíamos dizer que a primeira crítica à fé como manifestação religiosa suprema em seu sistema especulativo aparece na Fenomenologia do Espírito, especialmente no capítulo destinado à análise da cultura. Em uma das partes desse capítulo, temos um subtítulo chamado "o conflito da fé com a Aufklärung" que nada mais é que a apresentação de como a dialética

\footnotetext{
${ }^{62}$ Mais uma vez Jaeschke aponta nessa questão uma deficiência do texto dos manuscritos. Segundo ele, ao passar para o tratamento da relação da religião com a arte e a filosofia, ele dá a explicação do conceito de religião por encerrada, uma vez que a relação com as outras figuras do espírito absoluto não faz parte do conceito e da necessidade da religião. "Mas a necessidade também emerge como "como desenvolvimento da ideia e do material em seu elemento". Em sua última forma, contudo, a necessidade não é explicada no "conceito de religião" em nenhum grau maior que a transição para o ponto de vista religioso." [...] Após essas observações na demonstração da necessidade, Hegel parte pra discutir a relação da religião com a arte e a filosofia, um tópico que não tem lugar em seu programa original. Evidentemente ele considera o tema "necessidade do ponto de vista religioso" exaurido. Então ele acrescenta somente a descrição das formas do espírito absoluto." (JAESCHKE, 1986, p.238 e 239, tradução nossa). Devido a essas questões, nossa tentativa de dar conta do conceito de religião a partir da ideia de representação só é possível fazendo menção ao tratamento da questão nas outras obras de Hegel, que é nossa tentativa de aproximação com a Enciclopédia das Ciências Filosóficas e a Ciência da Lógica, tal como apresentada no último capítulo do presente texto.
} 
da cultura engendra a fé em oposição a um intelecto incapaz de ascender ao absoluto. Em suas palavras:

Como aqui a Religião - pois é dela que se trata - surge como a fé do mundo da cultura; ainda não surge como é em si e para si [...] Aqui porém a religião, por uma parte, emergiu da substância e é sua pura consciência; por outra parte, essa pura consciência é alienada de sua consciência efetiva: a essência é alienada de seu ser-aí. Assim, não é mais, certamente, o movimento carente-de-substância da consciência, mas tem ainda a determinidade da oposição frente à efetividade como esta efetividade em geral, e frente à efetividade da consciência-de-si em geral. Portanto, é essencialmente apenas uma fé (2002, p. 365 e 366)

Dizer que essa consciência é apenas uma fé, é mostrar que embora esteja relacionada com a religião (pois se trata do saber da essência absoluta) a fé não é ainda a religião completa. Se levarmos em conta a definição do conceito de religião presente nos manuscritos de 1821, encontramos consonância entre essa crítica e as definições dadas pelo texto, já que para o Hegel de Berlim, o problema da fé como manifestação da religião é que justamente o problema do culto, como veremos adiante. Por ora, basta-nos lembrar que nos mesmos manuscritos a religião é exposta como o conhecimento da verdade, pois a religião envolve o saber de Deus, seu lado objetivo. Segundo Charles Taylor,

Para Hegel, a religião é uma coisa mais generalizada. O que reflete um dado estágio da consciência de si do Geist é o conjunto da realidade religiosa, isto é, não só a ideia do absoluto, mas também a vida religiosa da sociedade como é vivida em seu culto. Tudo isso, e não apenas a teologia, reflete um certo entendimento do absoluto. A fé, enquanto estado mental de um indivíduo, é por conseguinte, apenas um elemento da vida religiosa na vida religiosa da comunidade em dado estágio da civilização. É simplesmente um aspecto abstrato, um "predicado" (2014, p.227)

O comentador da obra de Hegel aponta justamente para a questão do culto que falta à fé para se caracterizar como religião efetivamente. Mas onde Hegel formula a crítica nesses termos e o que ela significa?

Bem, a argumentação de Hegel nos manuscritos tem dois direcionamentos: um argumento contra a fé é em relação ao culto, e o outro é que a mera fé é um comportamento antirreligioso, pois se recusa a conhecer Deus. Os dois argumentos se complementam de certa forma, como veremos a seguir.

A mera consideração sobre Deus necessariamente acaba derivando em uma religião, pois somente na religião temos em consideração a crença e as práticas subjetivas em relação a uma representação determinada de Deus. E o próprio Hegel que nos recorda que "a theologia naturalis como reflexão sobre a mera ideia de Deus tornou-se inconsistente - estritamente falando, inespiritual" (1993, p.99). 
A razão dessa afirmação já foi apontada anteriormente. Segundo o ponto de vista especulativo, Deus deve ser considerado levando-se em conta a concepção de espírito, e como tal, deve ser manifestação e auto compreensão. Deus não somente deve ser, mas também deve compreender a si mesmo, em um movimento de saída de si para retornar a si próprio como autoconhecimento. Esse movimento se realiza pela mediação do espírito finito, que no caso da religião aparece como a comunidade crente. Em outras palavras, Deus só é completo se puder ser percebido por alguém, se puder ser venerado como uma divindade por uma comunidade, já que só dessa forma que a pura consideração do ser divino se realiza em uma religião, uma vez que nela entra em jogo a subjetividade e a forma como ela manifesta o Deus da teologia. E é justamente a partir dessa concepção de religião que Hegel tece suas críticas às filosofias da fé de seu tempo.

Primeiramente, temos a bilateralidade da religião: ela apresenta um aspecto objetivo, que é a representação de Deus, e um aspecto subjetivo, a percepção dessa representação e os atos do culto. Se por um lado o aspecto objetivo por si só não pode dar conta de Deus como espírito, também a pura consideração subjetiva da religião descamba para uma unilateralidade insustentável, não espiritual. O grande problema da religiosidade em voga no tempo de Hegel é o desprezo pela representação de Deus, tornando-o um conteúdo de impossível determinação. O Deus da fé é um Deus indeterminável e irreconhecível, aquele que não se pode representar. Vale a pena ler o trecho inteiro no qual Hegel tece sua crítica:

Esta é a especialmente a atitude e a forma de ver a religião em nosso tempo; a religião é uma orientação para Deus, um sentimento, discurso e oração na direção de Deus nos céus - mas somente na direção de Deus. Consequentemente, uma nulidade para Deus, um tiro no escuro - de acordo, significa que não sabemos nada de Deus, não temos familiaridade com o conteúdo divino, essência e natureza; somos orientados para um lugar que para nós está vazio (1993, p.100)

Após dizer isso, Hegel reafirma novamente a natureza do espiritual, sustentando em primeiro lugar, que o espírito é "essencialmente consciência” (1993, p.100). Dessa forma, deve ser objeto para a própria subjetividade a forma como ela é determinada. Consequentemente, Deus deve ser diferente da subjetividade que o reconhece, pelo menos em um estágio inicial. Por isso, Deus deve aparecer inicialmente como objeto para essa consciência, mas não, adverte Hegel, como algo exterior, mas intuído como a totalidade. Poderíamos compreender essa afirmação como o fato de que no espírito absoluto, campo onde se insere a religião, não se trata mais de apreender uma exterioridade que lhe faz frente, como 
era no caso do espírito finito. Agora se trata do próprio espírito que se manifesta como tal a si próprio $^{63}$.

A explicação sobre o problema da unilateralidade subjetiva da religião moderna deixa entrever o papel que Hegel atribui à religião em seu sistema, que é a de passagem, elevação da subjetividade finita à totalidade do espírito. Vejamos a primeira afirmação do qual partimos:

\begin{abstract}
A sensibilidade religiosa deve conter apenas isso, libertar-se de sua subjetividade e manter para si mesma o que é substancial, contra o caráter acidental de nossas opiniões, preferências, inclinações, etc. Esse conteúdo substancial é precisamente o que é fixado em si e para si, independente de nossa sensibilidade, e deve ser reconhecido como algo objetivo que subsiste em si e para si (1993, pp.100 e 101)
\end{abstract}

A definição da religião nesses termos de passagem e elevação não aparecem de maneira direta na parte inicial dos manuscritos, sendo melhor desenvolvida no trecho que aborda seu conceito especulativo ${ }^{64}$. Entretanto, a ideia de passagem/elevação é considerada quando Hegel se posiciona em relação à fé como parte incompleta da religião, como por exemplo, quando diz que "ser meramente orientado na direção de Deus não atinge seu genuíno, unificador e auto subsistente objeto" (1993, p.101), ou mais à frente quando afirma que "não atinge a verdadeira e atual renúncia de si mesmo" (1993, p.101).

O foco do argumento de Hegel é que faltando um elemento objetivo pelo qual orientamos nosso agir, isso é, o aspecto objetivo da religião que é a representação de Deus, nosso agir é vazio pois é um agir com vistas a lugar algum. "O culto contém ações, deleite, garantias, confirmações e a verificação de algo mais alto" (HEGEL, 1993, p.101), cuja falta implica em uma ação baseada somente na própria subjetividade. A ação baseada no próprio interior não pode alcançar o "algo mais alto" falado por Hegel, pois ele não é concebido. "Dar à religião somente uma direção subjetiva - meu coração é tudo - destruiu o culto" (HEGEL, 1993, p.101) já que "o que os indivíduos pretendem em relação a Deus depende de suas representações de Deus" (HEGEL, 1993, p.101 e 102).

O culto é justamente a ação humana em sua relação eterna com o absoluto. É uma ação que busca tornar o finito idêntico à sua essência, a seu Deus. E é por esse motivo que se deve representar essa essência de Deus de alguma forma, pois é ela que conduz a ação de

\footnotetext{
63 Por esse motivo na religião o próprio espírito aparece para si mesmo como um "acontecer", no qual as etapas de sua formação são uma história. Nesse sentido Klaus Vieweg afirma que na religião "a forma de comunicação desse acontecimento é o mito-lógico, uma narrativa do acontecimento divino, de uma história divina. O absoluto é tornado presente em sua forma objetual-intuitiva, é re-presentado.” (VIEWEG, 2007, p.15).

${ }^{64}$ Sobre a questão da exposição dos temas nos manuscritos de 1821 , ver nota 02 desse capítulo.
} 
modo geral. ${ }^{65}$ A questão da fé coloca em questão um conflito com o puro entendimento ${ }^{66}$ na medida em que ela é um acesso imediato ao exterior sem passar pelo crivo do pensamento. Como religião ela é mutilada, incompleta, pois lhe falta o lado da intelecção de Deus.

Essa questão da imediatez da fé remete diretamente para a questão da imediatez do início. O puro ser, inicialmente, é imediatamente também o não-ser, o nada, uma vez que sendo indeterminado, não tem significação alguma. Esse nada, entretanto, não é um simples nada, mas um nada determinado e, portanto, é também um ser, um ser abstrato e vazio. $\mathrm{O}$ nada e o ser se identificam nessa imediatidade abstrata sem serem a mesma coisa. A transição de um para o outro leva à superação da simples oposição inicial com o advento do vir-a-ser. A imediatez do início naturalmente, por sua própria abstração, conduz a uma dinâmica de afastamento da relação com o vazio de sua indeterminação, como já apontamos aqui anteriormente.

Pois bem, ser imediatamente ligado ao objeto que se experimenta ao mesmo tempo em que liga o sujeito ao objeto, imediatamente conduz esse objeto para o interior da subjetividade, assim como o ser simples e abstrato inicialmente é um só com o nada que lhe é oposto. É possível que por virtude dessa dinâmica, a fé seja considerada um instante primordial e inafastável da realização do conceito da religião, pois se inicia aqui o que somente poderá se realizar plenamente com o cumprimento da ideia especulativa do espírito, que é a superação das oposições e cisões.

Talvez por isso o desenvolvimento do papel da fé na construção e no desenvolvimento da religião seja primordial para Hegel, sendo que ele mesmo afirma que "é infinitamente importante ter enfatizado tanto esse lado subjetivo, o lado que Lutero chamou de fé, mas não é somente o único aspecto" $\left(1993\right.$, p.101) ${ }^{67}$. Isso aponta para a relevância da fé na realização

\footnotetext{
${ }^{65}$ A definição de Hegel para a noção de culto confirma essa posição: "Essa é a definição geral de culto: é a relação eterna, o processo eterno de conhecer no qual o sujeito se põe a si mesmo como idêntico à sua essência." (HEGEL, 1993, p.102.)

${ }^{66} \mathrm{O}$ desenvolvimento da contraposição da fé com a negatividade do entendimento foi longamente desenvolvido na Fenomenologia do Espírito, mas Hegel não repete nos cursos de Berlim os pormenores desse conflito, razão pela qual não entraremos nesses detalhes.

${ }^{67} \mathrm{O}$ feitio luterano da filosofia da religião de Hegel é marcante justamente por ele enfatizar a característica mais importante da religião como a fé. Não há religião sem esse momento inicial. Esse aspecto é discutido pelo próprio Hegel, que afirma na "História da Filosofia", que "nós, os luteranos (eu sou luterano, e faço tenção de continuar a sê-lo), possuímos apenas essa fé originária. Esta unidade não é a substância de Espinosa, mas é substância que se sabe a si mesma na autoconsciência, que se torna a si mesma indefinida e universal." (HEGEL, 1980, p.367). Ainda acerca do protestantismo de Hegel, Karl Löwith: "Nessa fé racional que sabe que o homem, no seu relacionamento imediato com Deus, está destinado à liberdade, Hegel se reconhecia como protestante. Desse modo ele intermediava a oposição decisiva que Lutero estabelecia entre a fé e a razão." (LÖWITH, 2013,
} 
do conceito de religião é a consideração do aspecto subjetivo da relação de Deus com os homens.

A questão de Deus é a mesma do início da filosofia: de fato, o puro ser é o resultado do trajeto do pensamento na Fenomenologia do Espírito, conforme abordado na Ciência da Lógica, de forma que sua consideração imediata seja justificada pelo progredir do pensamento através das negações e determinações até seu fundamento. A fé como princípio, deverá ser justificada na religião pelas representações que se farão sobre Deus e sua relação com o homem, já que esse tipo de conteúdo não pode se fazer presente de forma imediata.

Somente o avançar nas determinações pode conferir algum conteúdo, tanto ao simples ser, quanto a Deus, que segundo a consideração do crente é simplesmente um ser abstrato. Isso significa dizer que Deus inicialmente deve ser mediado tanto quanto o ser para ser efetivo: o universal é inicialmente abstrato, mas no fim do trajeto, como resultado, esse universal se torna efetivo. O que sabe a fé então se nada sabe sobre Deus? Sabe que nós O pensamos, e Ele está relacionado a nós. A importância da fé reside justamente neste fato: é através dela que o que inicialmente está separado substancialmente é unido: Deus e o espírito finito. A fé ao nos unir à divindade, liga, mesmo que de forma imediata, o infinito com o finito, dando início à tarefa que o conceito da religião tentará representar no fim de seu trajeto. Ora, o ser que é mediado pela fé tem a mesma natureza que o sujeito crente: ele é na mesma medida em que nós também somos.

A fé do mundo do esclarecimento, contudo, não avança para esse ponto. Ela se detém na simples afirmação de que há um Deus, mas se nega a dar-lhe contornos precisos por meio do pensamento. ${ }^{68}$ Esse problema recebeu uma crítica direta também na Enciclopédia das

p.24). Sobre essa influência da religião protestante luterana na filosofia da religião de Hegel, vide DIAZ, Hegel Y La Religión e (TAYLOR, 2014, parte I).

${ }^{68}$ Vale lembrar que essa oposição entre o aspecto objetivo da representação e a interioridade da fé é um evento que ocorreu no desenvolvimento da interiorização da substância, em um processo histórico bem definido pelo protestantismo. É com essa formulação que o cristianismo alcança o máximo da ideia de fé como pura interioridade, o que, na filosofia, corresponde à interpretação iluminista e romântica da religião. A ideia de fé como vínculo com a totalidade, e que isso implica em algo objetivo, não é invenção de Hegel. Na verdade, tudo leva a crer que essa noção é resgatada dos primórdios do cristianismo, quando se ligava a ideia de fé à de dogma, que por sua vez levava à noção de tradição. Assim como Hegel aponta para o fato da religião ter um conteúdo e um culto, os cristãos do século II entendiam que a regra da fé era a interpretação do Evangelho que condicionava uma forma de viver que mantinha a comunidade cristã unida. Manter a fé era manter uma forma de viver ancorada na história, ou seja, em uma tradição. Para o historiador do cristianismo Bernard Sesboüé, para o cristão dos primórdios "já existe uma consciência viva de que a fé cristã comporta uma normatividade, ou uma regra, ou ainda, artigos de fé" (2005, p.48). Ou ainda: "Como se exprime nessa época a referência ao Evangelho e uma regra da fé? Uma palavra a resume, "tradição" [...] Não se trata de tradição ou tradições diversas, trata-se da única tradição da fé, tradição recebida da pregação apostólica e sustentada por um povo e seus ministros. [...] Desde suas origens, a Igreja vive sob o regime da tradição.” (2005, pp. 50 e 51). Isso é o bastante para indicar a 
Ciências Filosóficas, que aborda o tema no capítulo destinado ao "saber imediato". Segundo os que defendem a imediatez ${ }^{69}$ como única fonte de verdade, em linhas gerais seguem o mesmo fundamento: que quando se concebe alguma coisa estamos tornando esse algo condicionado pela atividade do pensar, já que o pensamento nada mais é que a relação de categorias. Assim, no caso de Deus, fazer com que seja concebido é o mesmo que dizer que ele é condicionado, o que seria absurdo. "Anteriormente, descartavam-se de Deus as representações, chamadas antropomórficas, de toda espécie, como finitas e portanto indignas do infinito; e Deus se tornou, já por isso, uma essência muito vazia" (HEGEL 1995, p.140) Ou então:

Esse ponto de vista não se satisfaz com ter mostrado [a respeito] do saber mediatizado que tomado isoladamente é insuficiente para [alcançar] a verdade; mas sua peculiaridade consiste em que [segundo ele] o saber imediato, só tomado isoladamente com exclusão da mediação, tem por conteúdo a verdade (HEGEL, 1995, p.145)

Ainda sobre isso, Vieweg defende que

contra a fé como procurador do imediato Hegel faz valer o advogado do mediato, o representante consequente da relatividade, o cético e seu procedimento de destruição de todas as hipóteses prévias, de toda a certeza imediata pretensamente pura - o pensamento livre, independente, que examina, o pensamento da negatividade absoluta. A negação determinada também tem de ser realizada na religião (2007, p.25)

E a razão apontada na Enciclopédia para esse esvaziamento é a consideração das operações do espírito como atividades isoladas. Como vimos antes, o pensamento perfaz todas as distinções, mas enquanto algo é tomado em sua particularidade excluindo-se as demais determinações, não temos ainda a unidade do pensar. "Saber, crer, pensar, intuir, são categorias que se apresentam desse ponto de vista, as quais, por serem pressupostas como bem conhecidas, com demasiada frequência só são empregadas arbitrariamente conforme meras representações e distinções psicológicas; o que unicamente importa - sua natureza e seu conceito - não é examinado" (HEGEL, 1995, p.141). E por isso o defensor do saber imediato e da fé concebe o pensar e o crer como atividades opostas, ao mesmo tempo em que é forçado a admitir que o crer é um "saber" imediato, e, portanto, comporta algo do pensamento em si. A fé considera somente o simples ser, ou seja: que há Deus. Mas não pode

riqueza da trama resgatada por Hegel quando liga a fé a um conjunto de concepções de uma comunidade e a liga a uma forma de práxis que chamou de culto. Talvez a interpretação da fé como puro sentimento se dê contra a própria tradição do cristianismo. Podemos ver no Novo Testamento a ideia de fé como modo de vida no Ato dos Apóstolos: "E quando passavam pelas cidades, lhes ensinavam que guardassem os decretos que haviam sido estabelecidos pelos apóstolos e pelos presbíteros, que estavam em Jerusalém. E, com efeito, as igrejas eram confirmadas na Fé, e cresciam em número cada dia." (At, 16, 4).

${ }^{69}$ Vide caput do $\$ 62$ da Enciclopédia. 
dizer, o que é esse deus; imediatamente ele não é nada, é somente um universal, a potência infinita do Pai, e que por ter essa qualidade, não pode ser algo inteligível. "O que sabe esse saber imediato é que o infinito, o eterno, Deus - que está em nossa representação - também é, que na consciência está, imediatamente e inseparavelmente unida, com essa representação, a certeza de seu ser" (HEGEL, 1995, p.143). No campo da religião propriamente dita, e não uma simples crença em especial, "a certeza imediata da fé vale como uma determinação básica da representação. Na religião absoluta, o si-mesmo do espírito existente tem a forma da imediatidade total, a consciência de si imediata é a consciência da existência de Deus" (VIEWEG, 2007, p.24).

O conteúdo da crença em Deus é um conteúdo do mais alto ser, o que não pode ser objeto da intuição sensível. Somente se pode conceber tal coisa por força do pensamento, já que é impossível para a sensibilidade experimentar esse tipo de objeto. Assim, a pura intuição é o mesmo que o puro pensar. As duas determinações tomadas assim, de imediato, não dizem nada sobre o que se apresenta sob suas denominações, e é justamente esse o problema enxergado por Hegel nessa oposição da fé com o pensamento. "Quando se trata do mais elevado objeto, Deus, não é possível se fazer essa distinção entre as faculdades, sob o risco de se cair em contradição. Fé e intuição devem também ser tomadas como fé em Deus, como intuir intelectual de Deus; isto é, deve-se justamente abstrair do que constitui a diferença entre intuir, crer e pensar" (HEGEL, 1995, p.142).

A questão que se põe posteriormente são as contradições que essa posição imediata da fé coloca para a realização da religião. Começa a haver disparidade entre os opostos quando os lados relacionados (Deus e a consciência finita) começam a se contradizer por suas determinações. A identidade imediata do crente não se sustenta, já que se algo é crido, representado, ele só pode sê-lo na medida em que é conteúdo da consciência de alguém. Se há divergência, é porque deve haver uma característica em um dos lados que não pertence ao outro. Temos dois lados, o infinito e o finito, Deus e a consciência. 


\section{CAPÍTULO III: A REPRESENTAÇÃO NO SISTEMA E A RELIGIÃO COMO REPRESENTAÇÃO.}

3.1 Introdução:

Avançando na exposição sobre o conceito de religião, Hegel chega a um ponto no qual tem de distinguir a religião da arte e da filosofia, já que, uma vez que todas são parte do que chamou espírito absoluto, há de se eleger um critério que as distingua. Na Fenomenologia do Espírito a religião é apresentada em conjunto com a arte, sendo que apresenta uma "religião da arte", correspondente aos gregos. Já no período de Berlim ${ }^{70}$, a divisão do espírito absoluto se dá em correspondência com as formas da intuição, da representação e do pensamento, sendo que a passagem da forma inicial, a arte, se dá progressivamente até a filosofia por meio dessa ordem apresentada.

Nos manuscritos que são nosso objeto de exposição, a religião é considerada distinta da arte e da filosofia por estar no elemento formal da representação. A seção da intuição é destinada à arte, ao passo que à filosofia cabe a seção que trata do pensamento. Chega-se, por esta via, à análise da representação como questão que não pode ser afastada na compreensão desse tópico.

Ademais, segundo a exposição da religião na Enciclopédia, em um trecho citado no capítulo anterior, a religião "segundo a forma, é antes de tudo para o saber subjetivo da representação” (HEGEL, 1995, §565, p.347). Sobre essa manifestação do espírito marcada pela representação, Hegel diz que ela "dá autonomia aos momentos do conteúdo do espírito absoluto, e faz deles pressuposições, uns para com os outros, e fenômenos que se seguem uns aos outros, e uma conexão do acontecer segundo as determinações finitas da reflexão" (1995, $\S 565$, p.347 e 348). A religião, portanto, como atividade representativa, tem um "modus

\footnotetext{
${ }^{70}$ A Enciclopédia das Ciências Filosóficas, entretanto, apresenta na seção destinada à religião somente a religião revelada, isso é, a religião cristã. As formas precedentes ainda estão ligadas ao elemento da intuição, razão pela qual Hegel as deixou na seção que trata da Arte. Essa divisão não aparece nas preleções de Berlim, muito embora, como veremos, faz sentido entender a religião cristã como o acabamento da representação e a religião "por excelência", segundo esse critério.
} 
operandi" marcado por essa maneira de apresentar o conteúdo: como fenômenos que se seguem uns aos outros como um acontecer.

Os manuscritos, por sua vez, conforme vimos anteriormente, expõem a atividade da religião como uma relação do finito com o infinito, de forma que por meio do culto a esfera finita abandona sua finitude e se eleva a Deus. Em termos especulativos, poderíamos dizer que na religião há uma passagem do finito para o infinito, passagem que medeia o infinito. $\mathrm{O}$ que é possível extrair das passagens do texto dos manuscritos e pelo caminho que ele segue, é que a religião é um gradual abandono do que é imediato, já que falamos de uma "passagem" e de uma "elevação". A passagem para o infinito é a compreensão de que o que é essencial na divindade é algo que não se capta com os olhos e os ouvidos. Lentamente, assim, o crente deixa de entender o divino como presença imediata, compreensível pelos sentidos.

Esse é o caminho que se traça com decisiva virada no cristianismo, no qual o deus feito filho é morto. Tal fato é essencial para podermos entender esse abandono da presença, do imediato no espírito. Essa afirmação é feita seguindo os passos de Lebrun, que considera o cristianismo um "desfazer-se" da presença imediata. Como nessa afirmação, por exemplo, na qual lemos que: "o símbolo que melhor convém a Deus é, agora, o recuo em uma temporalidade em que seu rosto se esfuma. A nostalgia dos discípulos merece outra interpretação: ela mostra que, por excelência, Deus se oferece a nós sob o modo de ausência" (2000, p.34). O Deus encarado dessa forma é substituído por uma forma simples, mas não como aparece em elementos sensíveis como o sol, a água, ou mesmo nas estátuas como nos gregos. É um Deus que se apresenta para a subjetividade através da memória.

Caso a presença imediata fosse totalmente apagada, não faria mais sentido tratarmos de uma faculdade que não está ligada ao imediato. Sem imediatez, o espírito teria já superado a forma da natureza e estaríamos já no terreno do conceito realizado como ideia. A memória, como figura do espírito, ainda é uma das figuras da representação, conforme mostraremos logo a seguir. "E no cristianismo o peso do passado parece, para Hegel, um tanto menos abusivo, desde o momento em que se torna o símbolo de uma ruptura com o imaginário" (LEBRUN, 2000, p.35). Se é assim, permanece um problema a forma de caracterização da relação da religião com o positivo, pois para o cristão a relação com o elemento religioso não é mais com o Deus imediato, mas um deus mediado, deixado para trás no tempo.

A importância da questão da presença divina leva ao fato de que Deus, no cristianismo, se fez homem e se despojou desse corpo material. Dessa forma, a relação da 
divindade com a finitude não é a mesma que um criador e o criado. Nessa relação do cristianismo o criador se faz surgir na criação. Em outras palavras, a criação é o reflexo do criador e, nessa relação, temos uma manifestação, na qual se suprime a distância entre o manifestante e o que é manifestado ${ }^{71}$.

A representação como vimos acima, sendo memória, não consegue dar conta do apagamento dessa distância entre o manifestante e o manifestado. Existe algo de imediato, um resquício de presença nessa relação que nem o cristianismo, envolto já no manto da memória e da linguagem, consegue apagar.

A ideia de manifestação mesma traz consigo essa ideia de "aparecer no outro", conforme os termos da Enciclopédia, lá mesmo no conceito de espírito. Citamos um trecho do parágrafo 383 para ilustrar esse pensamento:

Sem dúvida, habitualmente se representa o manifestar como uma forma vazia, à qual
deveria ainda acrescentar-se um conteúdo de fora; entende-se então por conteúdo
algo essente-em-si, algo que em-si-se-mantém, e por forma, ao contrário, o modo
exterior da relação do conteúdo a outra coisa. Mas, na lógica especulativa, prova-se
que na verdade o conteúdo não é apenas algo essente-em-si, mas algo que entra
através de si mesmo, em relação com Outro; assim como, inversamente, na verdade
a forma não só não deve ser compreendida como algo não-autônomo, estranho ao
conteúdo, mas antes como o que faz do conteúdo o conteúdo, algo essente-em-si,
diferente do Outro (HEGEL, 1995, $\S 383$, p.25)

Portanto, ainda que o cristianismo, a religião mais "elevada" no sentido especulativo, consiga representar para si essa unidade da forma e do conteúdo na maneira da manifestação, se o nascimento de Cristo for entendido como uma simples passagem para outra esfera perdese todo o sentido do manifestar como identificação de conteúdo e forma.

Nos termos apresentados nos manuscritos, a elevação do finito ao infinito pode indicar justamente essa capacidade de entender o finito como manifestação do divino, do conteúdo. Assim, promove-se a identificação dos opostos. Para poder explicar como funciona essa elevação é necessário, portanto, entender o mecanismo da representação. O esclarecimento também tem de dar conta das disposições que apontamos na citação da Enciclopédia sobre a religião como representação, ou seja: de que ela apresenta seus conteúdos na forma de sucessão. Finalmente, outra questão pode surgir no interior da discussão, que é o porquê da religião, forma do espírito absoluto, se apresentar sob a forma da representação que é uma figura do espírito teórico finito.

\footnotetext{
${ }^{71}$ Cf, Lebrun, A Paciência do Conceito, em especial ao capítulo 01: "A crítica do visível”.
} 
Diante disso tudo nos resta responder à seguinte pergunta: O que é a representação? Com uma possível resposta pode-se ter uma pista sobre qual o funcionamento verdadeiro da religião no interior do sistema, e quiçá da relação entre a exposição do conceito que exploramos antes com as definições da Enciclopédia.

A análise da representação e da religião, portanto, seguirá as seguintes etapas:

a) A análise da ideia de representação, primeiro em sua exposição enciclopédica e em seguida como surge nos manuscritos. O confronto das exposições seguirá a uma possível interpretação do que seja a representação que Hegel se refere quando fala sobre a religião;

b) Em posse dessa noção, tentaremos estabelecer uma caracterização da religião como atividade representadora, no que realiza e no que deixa de realizar no trajeto de manifestação do espírito para si mesmo.

3.2 A representação no sistema - Caracterização como atividade do espírito teórico subjetivo.

A parte na qual Hegel dedicou ao estudo da representação é uma seção destinada à análise das etapas percorridas pelas formas do espírito teórico subjetivo. Vale lembrar que segundo a organização da Enciclopédia das Ciências Filosóficas de 1830, a última edição que fazemos uso no presente estudo, o espírito finito está divido em espírito teórico, prático e livre. A versão anterior da Enciclopédia não apresenta essa divisão tripartite, sendo que uma parte do que é apresentado na parte destinada ao espírito livre se encontra na seção destinada ao espírito objetivo. ${ }^{72}$

Vimos na exposição da ideia de espírito que ele é o racional que se entende como tal a partir de seu retorno da natureza. Esse ponto de exposição revela que as determinações objetivas são determinações perpassadas pelo espírito. Bem, isso nos diz o seguinte: “As produções do espírito são de acordo com a determinação da razão, de que o conteúdo seja

\footnotetext{
${ }^{72}$ Cf. HÖSLE, V. O Sistema de Hegel, especialmente na seção 6.4.1.
} 
tanto o conteúdo essente em si como, segundo a liberdade, o seu” (HEGEL, 1995, §443, p.216).

Ora, isso significa que o espírito inicialmente é determinado de forma dúplice. Ao mesmo tempo em que se sabe totalidade, o espírito deve elevar as suas determinações imediatas à forma da razão, fazendo-as assim idênticas a si, fazendo-as suas. De outro lado, o inicialmente interior do espírito deve sair dessa interioridade e se fazer objetivo, deve espiritualizar a determinação. Esse movimento dúplice é o movimento de realização do espírito na superação de suas determinações e, fazendo isso, torna-se livre (determinado por si mesmo).

Assim, essa via dúplice é no primeiro caso, espírito teórico, pois como tal tem "de lidar com o racional com sua determinidade imediata, e pô-lo então como o seu; ou libertar o saber da pressuposição, e assim de sua abstração, e tornar subjetiva a determinidade" (HEGEL, 1995, §443, p.216). No segundo caso, é espírito prático, que "tem um conteúdo que é só como o seu conteúdo: ele quer, de modo imediato, e liberta sua determinação volitiva de sua subjetividade" (HEGEL, 1995, §443, p.216).

Podemos dizer que o espírito é um transformar o imediatamente dado em algo interiorizado, tanto trazendo os objetos imediatos para o interior da subjetividade como fazendo com que a subjetividade se realize na determinação exterior. O caminho, inicialmente inverso nesses dois aspectos, termina por realizar a mesma coisa, que é a superação da unilateralidade do espírito imediato em relação às suas determinações.

O espírito é antes de tudo aquela atividade pela qual o objeto aparentemente estranho recebe - em vez da forma de um dado, de um isolado e contingente - a forma de um interiorizado [Erinnerten], subjetivo, universal, necessário e racional (HEGEL, 1995, §343, p.216)

Portanto, a forma de apreensão do que é determinante ao espírito é a atividade teórica, que por sua vez, também tem uma divisão tripartite. A divisão da parte teórica do espírito subjetivo é apresentada na seguinte sequência: a) intuição, b) representação e c) pensamento. Essa divisão tripartite é muito importante, como veremos logo a seguir, para a 
caracterização das formas de manifestação do espírito absoluto, pois elas seguem essa divisão proposta pela Enciclopédia ${ }^{73}$.

O que nos propomos a analisar na presente seção é a parte destinada à análise da representação nesse esquema. A representação é tratada na Enciclopédia das Ciências Filosóficas especificamente nos $\S \S 451$ até o 464. Nessa seção, é explicado que a representação é a "intuição rememorada" (HEGEL, 1995, §451, p. 234), ou seja, a representação é um estágio que está além da recepção imediata do sensível. Segundo a própria definição da Enciclopédia, "para a inteligência a representação é o seu, ainda com subjetividade unilateral; enquanto esse "seu" ainda está condicionado pela imediatez, não é, nele mesmo, o ser” (HEGEL, 1995, §451, pp.324 e 325). Cabe ao processo da representação interiorizar o que é colhido pela intuição e tornar esse conteúdo posto como algo seu, interiorizando o dado imediato ao mesmo tempo em que se objetiva através da posição de si mesma. Dissemos acima que o espírito tem inicialmente a determinação exterior do essente (o exterior encontra-se dado como algo em si mesmo determinado), mas não contém o dado da universalidade, do subjetivo, e assim, essa essencialidade do achar-se-determinado não é ainda "ser" no sentido da efetividade do conceito.

Foi dito agora acima que o processo representativo promove a posição do exterior como seu, mas ainda não de forma que esse conteúdo atinja o grau de "ser", ou seja, ser universal e efetivo. Isso é o mesmo que dizer que esse conteúdo mantém algo de essente, algo de exterior. Isso se comprova com a seguinte afirmação, do mesmo parágrafo 451 da Enciclopédia: “enquanto o representar começa da intuição e de seu material achado, essa atividade está ainda afetada pela diferença, e suas produções ainda são nela sínteses, que só no pensar se tornam a imanência concreta do conceito" (HEGEL, 1995, §451, p.235).

Até aqui podemos depreender que a representação é um estágio intermediário no qual o espírito consegue interiorizar os dados imediatos de sua determinação e os eleva à universalidade da subjetividade, porém não ainda na forma livre do conceito. Ela preserva em si algo da objetividade. Esse traço de objetividade aqui foi chamado por Hegel de "síntese". Adiante esclareceremos essa questão. O que nos propomos a apresentar sobre essa atividade

\footnotetext{
${ }^{73}$ Isso reforça o ponto proposto por Jaeschke e Chapelle exposto no capítulo anterior de que os textos de Hegel funcionam de maneira orgânica e sistemática, sendo que a abordagem conjunta dos textos e das preleções favorece uma melhor compreensão do sistema como um todo.
} 
representativa como posta no texto da Enciclopédia é que a representação é uma função do espírito subjetivo que funciona como meio termo entre a relação do achar-se imediatamente dado da sensibilidade e a universalidade da inteligência. Através da representação esse dado é significado (através da capacidade de significar), em um movimento que eleva o objeto à universalidade ao mesmo tempo em que faz da interioridade algo exterior, ou seja, "ser". Segundo Hegel,

\begin{abstract}
a representação é meio-termo no silogismo da elevação da inteligência: a ligação das duas significações da relação a si mesmo - a saber, o ser e a universalidade que são determinados na consciência como sujeito e objeto. A inteligência, mediante a significação da universalidade, completa o achado; e [completa] o próprio, o interior, mediante a significação do ser. (1995, §455, p. 240)
\end{abstract}

Por enquanto, mostraremos as três etapas de interiorização do conteúdo imediato descrito como representativos por Hegel, tal como surgem na sequência da Enciclopédia das Ciências Filosóficas com o intuito de expor como ocorre esse processo.

\title{
3.2.1 A rememoração:
}

A rememoração é o primeiro estágio da representação. Curiosamente, o estágio mais elevado da representação é a memória. É muito importante marcar bem que Hegel distingue os dois processos como coisas bem distintas. No grau da rememoração lidamos com imagens, ao passo que na memória evocamos signos, especificamente signos da linguagem. A diferença ficará clara ao término dessa exposição.

Como etapa inicial, que surge logo após a intuição, a rememoração recolhe o dado imediato em sua interioridade. Esse dado é chamado de "Imagem". A imagem não é mais algo dado na imediatez dos sentidos, mas algo recolhido na universalidade do Eu. Em outras palavras, no estágio da rememoração os dados sensíveis se tornam imagens que são armazenadas na subjetividade.

Lembramos que as determinações iniciais da natureza são o espaço e o tempo. $\mathrm{Na}$ medida em que o objeto é recolhido à interioridade e se faz uma imagem, ele é retirado dessa condição espaço-temporal da imediatez e é posto em uma espaço-temporalidade universal, uma vez que a subjetividade é a universalidade essente para si. A imagem apartada de sua 
espacialidade e temporalidade imediatas tem anulada sua presença imediata como tinha na sensação. Dessa forma, a subjetividade pode evocar essa imagem mesmo estando longe do espaço e do tempo originário do objeto. Como imagem ele não depende desse dado imediato.

Segundo Hegel, "a intuição se ofusca e se dissipa ao tornar-se imagem” (1995, §452, adendo, p. 237). Isso implica que a imagem é passageira e evanescente, não possuindo a vivacidade da sensação. Ela deve ser "rememorada" constantemente para ser fixada na subjetividade, e, por esse motivo, uma coisa deve ser vista diversas vezes para que possamos nos lembrar dela posteriormente.

Essa imagem está em nós de maneira puramente formal, uma vez que ela não mantém ainda nenhuma identidade conosco. "A imagem é o meu, pertence a mim; porém inicialmente não tem ainda, além disso, nenhuma homogeneidade comigo, pois não está ainda pensada, nem ainda elevada à forma da racionalidade” (HEGEL, 1995, §453, adendo, p. 238).

Essa questão está relacionada ao fato de que na rememoração a imagem interior precisa, para ser determinada como tal (para ter seu ser-aí) ser comparada à intuição, para a interioridade conseguir entender que a imagem não é mais o exterior, mas algo seu. No vazio do interior no qual as imagens aparecem aleatoriamente, apareciam somente como algo que a inteligência possuía. Assim, quando a inteligência recebe um dado da intuição e o compara com uma imagem interior e o percebe como algo "já possuído", a representação se manifesta em seu primeiro grau, no qual o interior agora "poder ser posto diante da inteligência, de ter nela um ser aí” (HEGEL, 1995, §454, p.239).

A partir da rememoração, chega-se ao segundo estágio do processo representativo, a imaginação.

\subsubsection{A Imaginação}

A imaginação é o processo mais longamente tratado por Hegel quando detalha o processo da representação, possivelmente por ser o estágio no qual se realizam os processos de simbolização e significação que são a chave da transposição do imediato para o universal da inteligência. O processo da imaginação surge através do estágio anterior, a rememoração, 
[Erinnerung] quando as imagens que surgem no interior não surgem aleatoriamente, mas o fazem segundo uma unidade, que é a inteligência.

Esse processo de evocação dessas imagens é o processo no qual o Eu, universalmente idêntico a si mesmo, trata essas imagens como suas e as relaciona segundo a própria subjetividade. E esse processo se aprofunda em três etapas sucessivas:

1) A imaginação reprodutora;

2) A imaginação associativa;

3) E finalmente a fantasia, que por sua vez se divide em fantasia simbolizante e fantasia significante.

Vejamos a exposição breve de cada processo.

\subsubsection{A imaginação reprodutora:}

No estágio da imaginação reprodutora, as imagens são evocadas, trazidas à presença da consciência sem auxílio da intuição, mas ainda arbitrariamente, sem uma regra que as unifique. O que diferencia esse estágio da simples rememoração é justamente o fato de conseguir ser "auto-ativa", de conseguir lidar somente com imagens independentemente da intuição. Esse estágio conduz diretamente para o seguinte, a imaginação associativa.

\subsubsection{A imaginação associativa:}

Nesse estágio da imaginação, a inteligência não somente evoca imagens do fundo de si mesma, mas as liga, as associa umas às outras. Entretanto, essas imagens que são ligadas tem uma marca completamente subjetiva, pois elas aparecem como marca de "minha arbitrariedade", ou seja, elas são ligadas segundo a subjetividade que põe a relação entre as imagens. A questão é que embora tenham essa marca de serem algo posto e relacionado pela inteligência, a relação que essas imagens possuem entre si é uma relação exterior, no sentido hegeliano de que não aparecem segundo uma relação intrínseca umas às outras, mas de 
maneira totalmente contingente. E podemos dizer isso seguindo Hegel, que nos esclarece sobre essa contradição nos seguintes termos:

Tenho diante de mim, por exemplo, a imagem de um objeto: a essa imagem liga-se, de modo totalmente exterior, a imagem de pessoas com quem falei sobre esse objeto, ou que o possuem etc. Com frequência é apenas o espaço e o tempo que fazem as imagens se alinharem umas às outras $(1995, \S 455$, p.242)

Hegel chama a atenção para o fato de que essas duas etapas da representação (a imaginação reprodutora e a associativa) possibilitam que se tenha representações universais, pois elas se originam de ligações entre imagens por características comuns entre elas. Essa característica comum só pode ocorrer à subjetividade após se decompor a imagem em suas múltiplas determinações e partir daí, comparar elementos que surgem também em outras imagens. A ligação decorrente desse processo é uma ligação por elementos que não são particulares, portanto, elementos universais.

Aquilo mediante o que as imagens se referem umas às outras consiste justamente no
que lhes é comum. Esse comum, ou é qualquer lado particular do objeto, elevado à
forma da universalidade, como por exemplo, na rosa, a cor vermelha, ou o
concretamente universal, o gênero; na rosa, a planta, mas em todos os casos [esse
comum é] uma representação que se realiza pela dissolução (procedente da
inteligência) da conexão empírica das multiformes determinações do objeto. Na
geração das representações universais comporta-se, assim, a inteligência como auto-
ativa (HEGEL, 1995, §456, p.243)

Bem, vimos ao longo do primeiro capítulo que a forma no qual a natureza se apresenta é justamente no espaço e no tempo. A natureza como ideia no elemento da exterioridade é basicamente a exposição de suas determinações de forma exterior, o que significa que estão colocadas umas ao lado das outras e surgem simultaneamente e sucessivamente. Se o processo de interiorização promovido pela representação visa tornar o essente dos dados imediatos da intuição universais através da inteligência, nesse processo da imaginação ainda não se pode dizer que existe uma superação plena da exterioridade, mesmo que esse conteúdo já esteja dentro da interioridade. É preciso que a associação seja de forma necessária, e não de forma natural.

Esse processo é levado a termo pela fantasia, através de seus processos de simbolização, em um primeiro instante, e de significação, em um segundo ponto. Só ao término desse processo é que a representação segue para seu estágio mais alto, a memória, que é ao mesmo tempo passagem para o pensamento.

\subsubsection{A fantasia}


A fantasia é o último estágio da imaginação, a segunda etapa da constituição da representação. Na fantasia, finalmente "a inteligência é implementada nela mesma como autointuição" (HEGEL, 1995, §457, p.244). Isso porque no elemento do fantasiar o universal e o particular do achar-se encontrado da intuição se unificam em uma coisa só. Segundo Hegel, somente no estágio da fantasia é que a inteligência consegue superar a mera síntese, uma vez que nos momentos precedentes o conteúdo era ligado de forma exterior, com salientamos um pouco acima. Segundo ele, "somente na fantasia a inteligência não é como um poço indeterminado e [como] o universal, mas como singularidade; quer dizer, como subjetividade concreta em que a relação a si é determinada [de modo] a que seja tanto o ser quanto a universalidade” (HEGEL, 1995, §457, p.245).

Anteriormente dissemos que o movimento de interiorização não visava somente a universalização do imediato, mas também que esse processo, levado às últimas consequências, também tinha por objetivo tornar a própria subjetividade concreta, ou seja, objetiva. É em relação a essa questão que a afirmação citada acima se refere. Na fantasia a subjetividade não é somente um interior, mas consegue, através de suas produções, pôr a si mesma como algo objetivo. A imaginação, tanto a reprodutiva quanto a associativa, produz um conteúdo que é recolhido da exterioridade e o eleva à universalidade, na maneira como temos acompanhado até aqui. Falta-lhe, contudo, fazer com que esse conteúdo interior seja exteriorizado, já que se trata, como temos insistido, de um movimento dúplice de interiorização do material da sensibilidade e exteriorização da inteligência. Portanto, a fantasia em sua capacidade simbolizante e significante é que inicia a exteriorizar a subjetividade ${ }^{74}$.

A fantasia é, portanto, inicialmente, uma atividade criadora de símbolos, na qual, para exprimir sua interioridade, escolhe um material de suas imagens para figurar a sua intenção. Assim, para exprimir a dureza e a resistência, representa esses adjetivos com uma rocha, que possui dureza suficiente para nos representar essas qualidades.

\footnotetext{
${ }^{74}$ A fantasia simbolizante produz símbolos, ao passo em que a significante produz signos. É importante observar que muito embora o processo de exteriorização da subjetividade já ocorra de certa forma com os símbolos, Hegel considera que somente o signo é adequado plenamente à objetivação, razão pela qual confere à linguagem a função significativa. Nesse sentido, Vitorio Hösle: "Hegel parece querer dizer que a forma da objetivação é especialmente adequada ao sinal, já que com ela está ligado um significado posto arbitrariamente, portanto imediato" (HÖSLE, V. 2007, p.440). Faremos essa distinção logo adiante entre o símbolo e o signo (chamado por Hösle de "sinal").
} 
A atividade simbolizadora não é ainda autônoma porque faz a representação, que é universal, depender do conteúdo da imagem que serve de símbolo. Assim, só podemos compreender a dureza e a resistência se tivermos em mente a imagem de uma rocha em particular. Usando as palavras de Hegel, "o conteúdo da representação universal a ser confirmado só se conclui consigo mesmo no conteúdo da imagem que serve de símbolo" (1995, §457, p.246). Por esse motivo, "a inteligência avança necessariamente da confirmação subjetiva presente no símbolo, e mediatizada pela imagem, até a confirmação objetiva, essente em si e para si da representação universal” (HEGEL, 1995, §457, p.246). Portanto, é necessário que a própria inteligência se faça totalmente objetiva no processo dialético, desvinculando-se da particularidade do conteúdo das imagens, o que só ocorre quando a imaginação alcança o estágio de ser fantasia significante.

O signo é, segundo as palavras de Hegel, "uma intuição imediata qualquer, que representa um conteúdo totalmente outro do que tem para si mesma" (1995, §458, p.247). Em relação ao símbolo, o signo se distancia na medida em que ele possui sua própria determinidade, não sendo necessário fazer nenhuma alusão ao conteúdo da intuição.

O signo é diferente do símbolo, de uma intuição cuja determinidade própria, segundo sua essência e conceito, é mais ou menos o conteúdo que exprime como símbolo; ao contrário, no signo, como tal, o conteúdo próprio da intuição e aquele do qual é signo, nada tem a ver um com o outro (HEGEL, 1995, §458, p.247)

A explicação para a diferença entre símbolo e signo já está dada. Ou seja: no símbolo, seu conteúdo ainda é totalmente dependente da verificação empírica da imagem, como no caso da pedra. No signo, essa relação é totalmente posta de lado, sendo que a inteligência confere um significado próprio ao signo. A inteligência é produtora do sentido do signo.

Assim, na fantasia significante temos a linguagem, como conjunto de signos que são a própria negatividade da inteligência, uma vez que, como significante, a subjetividade se porta como verdadeira negação da imediatez dos conteúdos da intuição. Agora, com o signo, a inteligência se determina a si própria no signo que produz, sendo que ela é sua produtora e também o que lhe confere significado. Para usar as palavras de Hans Belting, "vemos nas palavras apenas ilusões, e nos afastamos dela. [...] Uma vez abalada a fé que tínhamos nelas, dirigimo-nos ao signo, sobretudo a palavra" (2006, p.28).

Esse estágio, como dissemos é o da linguagem, o reino das palavras, no qual a inteligência se despoja dos resquícios da intuição e elabora um sistema de signos que tem uma 
referência à própria inteligência, e constitui o reino da representação por excelência, já que finalmente nesse estágio é possível falar na realização da interioridade do espírito.

O som que se articula mais para as representações determinadas, a palavra e seu sistema, a linguagem, dão às sensações, intuições, representações um segundo ser-aí, superior ao seu ser-aí imediato; e, uma existência que vigora no reino da representação (HEGEL, 1995, §459, p.248)

Isso ocorre porque quando damos nomes às coisas, fazemos com que uma produção interior da fantasia seja posta no mundo. Ao mesmo tempo em que esse nome é uma produção da inteligência, ele também é um dado percebido a partir de fora. No momento em que lidamos com um nome estamos recebendo de fora uma produção da própria interioridade, e não um dado sensível qualquer. $\mathrm{O}$ nome, instrumento linguístico por excelência, é uma criação subjetiva que modifica totalmente o sentido inicial de uma impressão e lhe dá a marca da livre manifestação do espírito: o nome é tanto uma criação subjetiva quanto seu significado é conferido por ela.

Com efeito, se resumirmos o que segundo as passagens mencionadas até agora fundamenta a excelência categorial da linguagem em Hegel, poderão assim ser indicadas as seguintes características sintéticas: a linguagem objetiva o sujeito, alheia o interior (HÖSLE, 2007, p.445)

Essa passagem de Hösle marca bem o papel que o signo opera na dinâmica do espírito teórico através da linguagem. E também com essa observação é possível entender a posição posta anteriormente de que o espírito cria uma nova existência a partir de sua operação onde ele se coloca para si mesmo. Esse trajeto de interiorização do exterior e exteriorização do interior se realiza com a operação da linguagem. Ainda conforme Hösle,

O que segundo ele constitui sua essência [da linguagem] é o fato de o espírito dar, a partir de si, às noções formadas a partir das imagens da intuição uma existência exterior e, no entanto, ao mesmo tempo, ideal, criada por ele mesmo (2007, pp.440 e 441)

Contudo, a linguagem só se efetiva totalmente se ligada à memória, a última figura da representação, já que é necessário que a inteligência ligue o nome a um significado. A operação que faz essa ligação entre a intuição produzida pela inteligência e sua significação é a memória.

\subsubsection{A memória}


A memória é parte da efetivação da linguagem. Isso porque só podemos falar efetivamente de uma linguagem quando podemos fazer a ligação da representação, o interior criado, com a intuição enquanto algo vindo de fora.

O nome, enquanto ligação da intuição produzida pela inteligência com o seu significado, é antes de tudo uma produção singular passageira; e a ligação da representação, enquanto algo interior, com a intuição, enquanto algo exterior, é ela mesma exterior. A rememoração dessa exterioridade é a memória (HEGEL, 1995, $\S 460$, p.253)

A palavra enquanto signo só é fixada em seu significado por uma operação da memória, que repetidamente liga o nome ao significado que lhe é conferido. O mecanismo da memória, no esquema da Enciclopédia, tem três estágios, iniciando pela memória que conserva os nomes, seguida pela memória reprodutora, e finalmente, a memória mecânica.

A diferenciação nesse esquema é simples. A memória, inicialmente trata de fazer o que dissemos acima: gravar o significado dos nomes, os signos. Só assim chega à segunda fase, que é a memória reprodutora. Com a memória reprodutora não se faz mais nenhuma alusão à imagem, pois nesse domínio a inteligência já "absorveu” o nome e seu significado.

Vale notar que esse mecanismo operado pela memória é exatamente o que é realizado pela rememoração no início do percurso representativo, no qual o conteúdo da intuição é fixado interiormente como imagem. A diferença entre a rememoração [Erinnerung] e memória [Gedächtnis] é justamente o que é interiorizado. Na rememoração é um conteúdo sensível. Na memória, por sua vez, é um produto do espírito, o signo que é recepcionado pela inteligência. Hegel se refere a essa repetição diretamente no §461 da Enciclopédia das Ciências Filosóficas: "Como memória, a inteligência percorre, com referência à intuição da palavra, as mesmas atividades da rememoração que percorre enquanto representação em geral, com referência à primeira intuição imediata” (1995, §461, p.253).

Sobre a operação que indicamos a respeito da linguagem:

O nome, como existência do conteúdo na inteligência, é a exterioridade da inteligência nela mesma, e a interiorização [Erinnerung] do nome, como [sendo] a intuição por ela produzida, é ao mesmo tempo a extrusão [Entäusserung] na qual ela se põe no interior de si mesma (HEGEL, 1995, §462, p.254)

O exemplo dado por Hegel para ilustrar essa passagem da memória que conserva nomes para a memória reprodutiva é muito claro: "No nome "leão" não precisamos nem da intuição de tal animal, nem mesmo também da imagem: mas o nome, enquanto o percebemos, é a representação simples sem imagem. É em nomes que nós pensamos" (1995, §462, p.254). 
Essa operação da memória em interiorizar os signos exposta na Enciclopédia deixa claro que para Hegel a linguagem está sempre no domínio do universal. Mesmo quando se faz referência a alguma coisa sensível, o signo da linguagem que lhe faz menção está sempre no domínio geral, pois a palavra é construída pelo movimento da representação. Esse movimento é a elevação do singular à forma da universalidade. Esse mecanismo já aparecia no início da Fenomenologia do Espírito a respeito da certeza sensível; não podemos enunciar o "isso", o particular. Quando tentamos fazê-lo expomos o universal, o "isso” universal.

É por esse motivo que Hegel afirma que "só sabemos de nossos pensamentos, só temos pensamentos determinados, efetivos, quando lhe damos a forma da objetividade, do ser-distinto de nossa interioridade" (1995, §462, p.255). Isso reforça outra afirmação anterior de Hegel de que "é em nomes que nós pensamos". Na operação de elevação do particular ao universal efetuada pela linguagem, desvanece tanto o singular da intuição quanto o Eu particular. Hösle, para quem a questão da linguagem é muito importante devido à sua atenção ao problema da intersubjetividade no sistema de Hegel, reforça que

Enquanto a linguagem é obra do pensamento, também nela não pode ser dito nada que não seja geral. O que eu apenas acho é meu, pertence a mim enquanto este indivíduo específico; se, no entanto, a linguagem apenas expressa uma coisa geral, então eu não posso dizer o que eu apenas acho (HÖSLE, 2007, p.442)

Esse aspecto da linguagem perfaz finalmente seu caráter universal no sistema hegeliano, pois muito embora o indivíduo, o Eu particular, tente exprimir a si próprio, ele sempre o faz de forma universal através da linguagem, ou seja: exprime-se no elemento do espírito e não do indivíduo.

O fato do pensamento só poder se exprimir pela linguagem também afasta totalmente a pretensão de fazer o inexprimível e o sentimento terem um lugar elevado na efetividade,

pois, embora se pense que o inexprimível seja justamente o mais excelente, essa
suposição, nutrida pela vaidade, não tem o mínimo fundamento; porque o
inexprimível, na verdade, é somente algo turvo, fermentante, que só ganha clareza
quando consegue chegar à palavra (HEGEL, 1995, §462, p.256)

Entretanto, esse estágio linguístico não se resolve diretamente como pensamento. Há de se ressaltar que enquanto ainda existe a distância entre o significante e o significado, ainda persiste a oposição da interioridade e do exterior, e, nos termos da dinâmica do espírito teórico da Enciclopédia, entre o essente e o ser. Ora, mas por que? Porque, segundo Hegel, "enquanto a conexão dos nomes reside na significação, a ligação desta com o ser, como nome, é ainda uma síntese; e a inteligência, nessa sua exterioridade, não retornou a si de modo 
simples.”(1995, §463, p.256). Isso quer dizer que ainda persiste o elemento do "um-ao-ladodo-outro" que marca as relações espaço-temporais da natureza. A verdade da coisa necessita ainda da inteligência significadora para ligar o nome a algum sentido. Somente como memória mecânica essa distância se apaga, quando a memória se coloca como a identidade desses dois opostos, pois nela a inteligência se sabe ativa, razão.

A memória, dessa maneira, é passagem para a atividade do pensamento, que não tem
mais significação: isto é, o subjetivo não é algo diferente de sua objetividade, assim
como essa interioridade é, nela mesmo, essente. [...] A memória como tal é, ela
mesma, o modo apenas exterior, o momento unilateral da existência do pensar; a
passagem é, para nós ou em si, a identidade da razão e do modo de existência; essa
identidade fez que a razão exista então em um sujeito como atividade sua: assim a
memória é o pensar (HEGEL, 1995, §464, p.258)

Entretanto, nessa transição a representação já foi superada. O que pode se depreender desse trajeto da representação na Enciclopédia é que a inteligência consegue se realizar nessa figura quando consegue colocar objetivamente a interioridade, fazendo isso através da interiorização dos dados sensíveis e os elevando à forma da universalidade. Pesa contra a representação, contudo, o fato de não conseguir abolir totalmente através desse processo a distância entre o significante e o significado, o que quer dizer que seu processo de elevação do sensível ao universal pela linguagem ainda mantém elementos da exterioridade, que é o persistir do um ao lado do outro, o significante e o significado, bem como enunciado lá no início da explicação de Hegel sobre a representação, especificamente no parágrafo 451.

Essas linhas devem, de certa forma, estarem presentes na caracterização da religião como uma figura representativa do espírito absoluto nos manuscritos das preleções de 1821 . Cabe a nós, nesse momento, fazermos uma análise dessa questão e tentar fazer a devida ligação entre os textos.

3.3 A religião como representação nos manuscritos de 1821.

A representação é o critério utilizado por Hegel nos manuscritos para diferenciar o momento religioso do espírito absoluto em relação à arte e à filosofia, especificamente na última parte da apresentação do conceito de religião, que se intitula justamente "A relação da religião da arte e da filosofia". 
Essa distinção se faz necessária na medida em que tanto a arte quanto a filosofia guardam em comum com a religião o fato de serem o instante no qual a verdade é objeto para si mesma no espírito absoluto, ou seja, o fato de ele ser sujeito e objeto. Conforme o próprio Hegel nos recorda, "essencialmente é uma questão da forma na qual a verdade absoluta aparece na religião" (1993, p.142) já que o conteúdo é o mesmo das outras formas do espírito absoluto.

Hegel faz uso, assim, do mesmo esquema tripartite que está presente na Enciclopédia das Ciências Filosóficas na seção destinada ao espírito teórico que apresentamos brevemente acima. Vejamos:

A forma da distinção da religião da arte e da filosofia cai consequentemente
estritamente - inicialmente - na determinação de sua relação objetiva, pois
precisamente a relação mesma é a distinção da forma [da religião]. Agora essa
relação pode ser nada mais que uma teórica, uma modalidade de consciência, pois
ela concerne à forma, a objetividade como tal. Ela tem o caráter a) de intuição
imediata, b) da representação, e c) do pensamento, no sentido estrito do conceito,
pensamento especulativo do que é verdadeiro (HEGEL, 1993, p.143)

Portanto, para nossos propósitos, cabe analisar o que confere especificamente à religião nessa explicação de Hegel sobre a particularidade da religião, cuja forma concerne à representação. Ao elemento da intuição imediata corresponde a forma da arte. E para Hegel, logo de início, o que distingue a representação da intuição é sua dissociação da imagem nos seguintes termos: "Mas desde que a religião é ela mesma o elemento subjetivo da auto consciência, a representação [Vorstellung] é totalmente mais importante para ela representação como distinta da imagem" (1993, p.147).

Esse processo de afastamento do imediato é justamente o descrito nas passagens da Enciclopédia citadas anteriormente, nas quais o imediato da imagem é elevado à forma da universalidade subjetiva. Assim, o percebido inicialmente pela intuição é elevado à imagem, e a partir daí, como vimos, a imagem vai sendo depurada até aquele que lhe confere significado, isso é, a inteligência, tornar-se objetiva por si só, sem intermédio do sensível.

Entretanto, surge para o interprete de Hegel a espinhosa questão da representação na religião com o seguinte questionamento: em que medida essa descrição feita por Hegel acerca da dinâmica do espírito na religião corresponde ao esquema da representação apresentado na Enciclopédia? Pelo que expomos acima na ocasião da exposição da representação no espírito teórico subjetivo, as figuras da representação também se mostram presentes na apresentação da arte no espírito absoluto, sendo que não é simples delimitar exatamente qual o limite entre 
o artístico e o religioso. Levando em conta o que Hegel expõe nos manuscritos acerca da atividade religiosa, como interpretar essas passagens à luz do esquema sistemático apresentado na Enciclopédia das Ciências Filosóficas?

Esse problema aparece, por exemplo, quando Hegel expõe nos cursos de Estética, que "o símbolo, no significado que damos aqui à palavra, constitui, segundo o conceito bem como segundo a aparição [Erscheinung] histórica, o início da arte.” (2014, p.25). Ora, como vimos acima, o símbolo é um mecanismo do espírito que já está no limiar do signo, e está em um nível da representação no qual já há algum afastamento da intuição, inicialmente ligada ao elemento artístico. O próprio Hegel confirma isso logo em seguida quando diz que

O símbolo em geral é uma existência exterior imediatamente presente ou dada para a
intuição, a qual porém não deve ser tomada do modo como se apresenta de imediato,
por causa dela mesma, mas deve ser compreendida num sentido mais amplo e mais
universal. Por isso, devem ser distinguidas a seguir duas coisas no símbolo: primeiro
o significado e depois a expressão do significado. Aquele é uma representação ou
um objeto, indiferente de qual conteúdo, esta é uma existência sensível ou uma
imagem de qualquer espécie (2014, p.26)

Já vimos que o mecanismo da representação eleva o material da intuição à forma da universalidade, e que o mecanismo simbólico, por exemplo, é uma parte no qual o espírito lança mão de imagens, mas lhe dá a significação por conta própria. Isso é o bastante para mostrar que a divisão proposta na Enciclopédia não permite uma justaposição automática ao espírito absoluto sem que tenhamos feito algumas observações antes. Sendo assim apresentaremos algumas questões:

Para responder ao questionamento acerca da representação na religião que é central na argumentação de nossos propósitos aqui, lançaremos mão de noções que já apresentamos anteriormente, especialmente no que diz respeito a como Hegel entende a efetivação do espírito como presença do sentido. Veremos, logo à frente, que ele articula noções como a superação da figuração e da significação para dar sentido à forma da religião em relação tanto à arte quanto à filosofia.

Segundo expomos na parte destinada à dinâmica representativa do espírito teórico subjetivo, a representação diz respeito a um estágio que é, inicialmente, ainda ligado ao sensível, pois ela ainda é imagem. Aliás, é pela exposição de figuras como a imaginação e a fantasia que também é possível caracterizar e compreender diversos aspectos da atividade artística, como visto com o problema do símbolo. Vejamos o que pode ser dito sobre o problema da figuração e do sentido. 
Lebrun $^{75}$ chama a atenção para o fato de que a "Bildung" em Hegel apresenta a forma geral de uma rearticulação entre a subjetividade e a objetividade que lhe parece, inicialmente, contraposta. E faz isso efetivando o conceito. Essa efetivação do conceito envolve a objetividade do subjetivo, de forma que a distância entre o sentido e o significante seja abolida gradualmente. Esse aspecto da dinâmica da filosofia de Hegel apresentamos no primeiro capítulo. Em relação ao sentido da figuração, podemos entender essa "depuração" do imediato pela representação como uma reavaliação do sentido da figura, de forma que

o sentido não se aloja mais em uma presença representada (o ente), um foco representante (o sujeito) e uma instância apresentante. [...] Representar-se algo é renunciar à sua presença, dobrar imprudentemente o que pretendo conhecer com uma espessura que, justamente, o furta do Saber" (LEBRUN, 2000, p.59)

Contudo, a representação seria uma nova figura, ou seja, uma figura mais adequada ao espírito que a imagem? Somos levados a crer que não, pois a elevação da imagem através da representação é o apagamento da figuração. Ao tornar a imagem símbolo e signo o espírito age para eliminar a distância entre o sentido e o significante, tornando o espírito concreto, tanto sujeito quanto objeto, conforme vimos antes. Assim, "ao tornar-se a própria figura, o sentido anula a própria estrutura da figuração. Não há, portanto, compromisso entre o sentido e o visível: a elevação daquele é o apagamento desse" (LEBRUN, 2000, p.60).

Isso nos conduz a uma formulação central para nosso propósito acerca da religião como representação: a de que o conhecimento é a anulação da distância entre o significante e o significado. Isso quer dizer que quando Hegel diz que a religião é distinta da imagem ele nos diz que o saber não pode mais se contentar em dizer que o sentido de algo é apresentável, que possa ser exposto em presença física, temporal e espacial. "Uma significação presente não será mais uma significação enfim oferecida; ao contrário, ela dirá a vaidade de toda abordagem e toda apresentação" (LEBRUN, 2000, p.60).

A apresentação é diretamente relacionada com a questão da aparência, já que o que é apresentado "aparece" para nós de alguma maneira, nos advém de fora. E é o tratamento que o espírito dá ao que aparece que marca a distância da mera imagem em relação à representação. Na esfera da arte é que inicialmente o espírito começa a negar o imediato,

pois tudo o que existe tem, por isso, apenas verdade na medida em que é uma existência [Existenz] da Ideia. Pois, a Ideia apenas é o que é própria e verdadeiramente efetivo. O fenômeno [das Erscheinende], a saber, não é ainda verdadeiro apenas porque tem existência [Dasein] interior ou exterior e é em geral

\footnotetext{
${ }^{75}$ Cf. Lebrun, 2000, capítulo 01.
} 
realidade, mas somente porque esta realidade corresponde ao conceito (HEGEL, 2001, vol. I, p.125)

Isso quer dizer que do imediato o espírito deve apreender o que corresponde a seu conceito e o faz depurando, por assim dizer, os elementos contingentes de sua aparição. O que o espírito realiza, portanto, quando nega o imediato na arte, é mostrar imediatamente a nulidade de toda imediatez. O mesmo Lebrun nos recorda que "ela lhe proíbe, por exemplo, ser pura e simplesmente reprodução" (2000, p.60), o que indica que a imagem na arte já é uma produção espiritual que suprime o elemento imediato da sensação e reapresenta a imagem no que tem de espiritual. Essa aparência, portanto, é o indicar para o espírito da naturalidade que se deixou de lado na imagem. Ou seja: o objeto apresentado na arte indica que ele é algo totalmente diverso do sentido que apresenta em seu estado natural. É como se na obra se indicasse justamente que o sentido não está no objeto em seu sentido habitual, que ele tem um sentido além do imediato.

A nulidade do imediato é a verdade da existência do espírito. Mas como essa negação se dá somente imediatamente na obra de arte, o afastamento definitivo do espírito em relação à imediatez não pode se realizar totalmente na forma da arte, pois há um limite no qual a aparência não consegue mais apresentar para o próprio espírito a nulidade do que é imediato: ela começa a ruir como forma em relação ao conteúdo que tenta manifestar. Da arte como forma dizemos que "ela já não tem à sua disposição matéria para mostrar a nulidade do imediato. Inútil: para que se demorar mostrando ou sugerindo a nulidade do imediato, quando o imediato se suprime efetivamente" (LEBRUN, 2000, p.63)?

Essa aparência traz em si mesma a negação da própria forma, já que ela mesma é uma negação da imediatez. Assim, negar a imagem conduz ao estágio que Hegel apresenta na Enciclopédia no qual a imagem se transforma em signo, no qual não há mais a mediação pelo imediato, mas sim pela própria subjetividade, num processo em que cada vez mais imediato sempre se suprima. Esse trajeto foi indicado linhas acima. Na medida em que a aparência estética suprime a existência imediata, ela deve ir até o ponto em que ela mesma aponte para sua insuficiência, e é a partir de então que se inicia o domínio da palavra sobre o aparente.

E então chegamos ao ponto no qual as palavras de Hegel nas preleções da filosofia da religião se tornam mais claras, já que, segundo ele, o que marca a religião é justamente o fato de que "a representação religiosa, portanto, tem a característica de ser verdade contra o figurativo e precisamente contra o todo da modalidade imperfeita da intuição e das imagens." (1993, p.149). O figurativo é justamente o que dissemos acima a respeito da relação entre o 
sentido e o significante. Enquanto permanece a figuração, o sentido do imediato é sempre remetido para um outro, o sujeito que lhe confere sentido. O significante, o sujeito, continua distante de seu significado, o objeto. A figura remete para algo além dela mesma, como atesta o processo estético inicialmente com a existência das imagens. A religião é

\begin{abstract}
essa elevação que é ligada com a rejeição do figurativo - uma rejeição que parece inicialmente dizer respeito somente à forma mas na verdade concerne ao conteúdo também, na medida em que a opinião religiosa estava ligada ao figurativo; e o figurativo, o belo, tem precisamente o significado que o universal, o pensamento, o conceito não está separado da imagem [Bild]. Um símbolo pressupõe reflexão, a presença da separação (HEGEL, 1993, p.149)
\end{abstract}

Assim, como a religião dá a seus conteúdos a forma da representação, ela tem um conteúdo que é desvinculado da necessidade da aparição imediata, do sensível, e diz respeito ao interior da subjetividade. Em outras palavras, podemos dizer que na religião o espírito adequa a sua forma de manifestar seu distanciamento do imediato, desta vez não mais feito pelo sensível da arte, mas pela interioridade da devoção [Andacht]. Na medida em que é representação, ela se dá um conteúdo objetivo pela doutrina, a verdade que lhe surge não é somente posta para ser apreendida pelos sentidos, mas é uma verdade atestada pelo espírito, é uma verdade que está em nós.

Isso marca uma distância do figurativo na medida em que o conteúdo não é dado imediatamente pela intuição, mas é mediado pelo processo de abstração. Assim, o imediato, o figurativo, é elevado à forma da universalidade, implicando, como vimos no processo da Enciclopédia, uma rejeição da figuração. Na religião o espírito compreende que o absoluto não pode ser apresentado na forma de uma imagem ou aparência, e, portanto, indica uma inadequação entre o sentido e a imagem.

Esse ponto é importante para marcar bem a posição da religião frente ao elemento artístico, pois a caracterização da religião nos manuscritos também contém elementos que não pertencem exatamente à descrição da representação da Enciclopédia, como o sentimento e a intuição. Nesse ponto a fé marca a religião, pois nela o conteúdo é imediatamente identificado com a subjetividade, numa clara posição diversa ao figurativo. Aqui a distância é inicialmente abolida; o significante se identifica com o significado. Segundo Hegel, "a fé é o testemunho interior do espírito, consequentemente, não um testemunho histórico, aprendido, um sem a necessidade do conceito e sem a determinação como minha determinação" (1993, p.153) ${ }^{76}$.

\footnotetext{
${ }^{76}$ Sobre a caracterização da fé nos manuscritos, ver o capítulo 02 do presente texto.
} 
Mas a fé como forma da religião expõe inicialmente um essente diante de mim, cujo conteúdo é o pensamento desenvolvido, como um conjunto de dogmas e doutrinas na forma da imediatez. Isso traz a argumentação e a ação da reflexão, que como vimos no capítulo anterior, inserem a diferença e a oposição na unidade inicial da devoção religiosa.

Com efeito, ao alcançar esse ponto, a reflexão começa a demolir a unidade criada pela interioridade da religião. A totalidade da vida ética também começa a ruir.

O início da reflexão, em particular, que vai além do agarrar-se rapidamente ao que é dado, pode e me confunde, e a confusão é mais perigosa e séria na medida em que o ético e tudo o resto relacionado a mim, na vida, na atividade e o Estado, é enfraquecido pela confusão relacionada a essa região (HEGEL, 1993, p.155) ${ }^{77}$

No estágio final da ruptura provocada pela reflexão, temos enfim uma subjetividade que se sabe fundamento total de tudo. Nesse quadro, é a religião que chega ao ponto da insuficiência, pois ela não é mais capaz de unificar o significante e o significado através da devoção. A religião em seu acabamento, portanto (assim como a arte é em relação ao religioso), uma passagem para a filosofia, que se movimenta, por assim dizer, no terreno do pensamento (entendido no sentido especulativo como a forma do conceito).

Desse modo, a representação da religião tem a função de fazer uma dupla marcação: em um primeiro momento, da representação religiosa frente ao artístico e em num segundo momento em relação ao pensamento conceitual. A representação diz respeito a um conteúdo que não consegue mais ser apontado imediatamente pela aparência estética, necessitando assim da confirmação e da unificação imediata da subjetividade. Por ter elementos comuns à arte e à religião, essa última é, pelo menos inicialmente, identificada com a arte, como diz Hegel nos manuscritos berlinenses de 1821: "em relação à consciência e seu conteúdo, contudo, não é ligada e estritamente limitada pela forma da intuição imediata e imagem mítica. Para ser preciso, deve haver uma religião cuja intuição ocorre essencialmente no modo da arte" (1993, p.147).

Como vimos anteriormente, o que marca a religião é possuir um distanciamento maior em relação ao figurativo que a intuição imediata, domínio das artes, justamente por seu modo de realização se dar pela interioridade. Embora habite uma região em comum com elementos da arte e da filosofia, na religião há um momento no qual a imagem e o figurativo são

\footnotetext{
${ }^{77}$ O ponto máximo desse procedimento é a cultura romântica da ironia, citada nos manuscritos de 1821 somente de forma implícita. Hegel não entra em detalhes sobre esse assunto nesse texto, muito embora a questão seja de grande relevância na literatura hegeliana. Sobre o assunto, vide PÖGGELER, O. Hegels Kritik der Romantik. München, W.Fink, 1999.
} 
somente um momento da realização do religioso, e não um elemento essencial de sua realização como acontece com o imediato na $\operatorname{arte}^{78}$.

Mas para marcar bem o espaço da religião em relação ao figurativo $\mathrm{e}$ consequentemente sua diferenciação em relação à arte, lembremos que, segundo o esquema enciclopédico, o ponto no qual a representação se realiza de fato sem o recurso ao imagético é com a fantasia significadora, ou seja, com a linguagem. Se inicialmente existe uma religião que se identifica com a arte, ela não é a forma absoluta da religião, que lentamente se encaminha para formas de reconciliação com o absoluto mais voltadas para o interior, e consequentemente, acabam sendo mais representativas nesse sentido. A linguagem é a primeira "conquista" da representação no sentido que ela se desprende finalmente do imediato sensível, mas mesmo a linguagem é somente um primeiro passo nessa direção efetuada pela representação. A representação vai além da linguagem até a memória, como vimos anteriormente. No ápice do cristianismo no sistema hegeliano que é o protestantismo, nada mais resta de imagético na relação com Deus, mas somente sua palavra.

Acrescente-se o fato de que na religião o sentimento também é uma espécie de forma, igualmente como no interior da arte e da poesia. Mas aqui novamente é necessário reconhecer as respectivas mediações, uma vez que a representação nos campos da arte e da religião está sempre submetida à determinação de cada uma das Formas do espírito absoluto (WERLE, 2005, p.91)

Por isso, a imagem na arte é a realização máxima que ela pode alcançar como forma, ao passo que a linguagem está no limiar do representativo quando se desvincula do imediato. O artístico, mesmo quando faz uso da linguagem, que pertence ao âmbito da representação, o faz orientando o espiritual para a aparição sensível. Logo, mesmo quando tratamos da poesia, que tem por elemento a representação, ela apresenta o espiritual na imagem e na palavra a ser dita. "Este apreender, configurar e proferir permanecem puramente teóricos na poesia. Não a coisa [Sache] e sua existência prática, mas o tornar imagem [bilden] e o falar são a finalidade da poesia” (HEGEL, 2004, p.24). O religioso ao contrário, parte, como vimos, do ponto principal que é a separação entre o universal e o particular, de modo que sua forma de apresentação, pela própria natureza dessa cisão, é prosaica. Assim, o representar do espírito se afirma inicialmente como interioridade pela linguagem, mas não se restringe por ela, sendo a representação um domínio mais amplo. E essas características

\footnotetext{
${ }^{78}$ A representação é um elemento da poesia, última e mais elevada forma de arte no esquema estético de Hegel. Entretanto, a representação na poesia não é exatamente o mesmo que na religião, pois nesse caso o representativo se dá em função do imediato, ou seja: a representação se dá em função de sua exposição imediata para a poesia. Na religião há um distanciamento dessa necessidade de presença imediata.
} 
Resumindo, a articulação entre a linguagem a representação pode ser fixada segundo dois aspectos: (1) a linguagem possui uma função dentro do campo maior da constituição da representação, ao passo que (2) a representação é um determinado domínio, tal como a intuição (WERLE, 2005, p.117)

Quando a religião se imiscui na interioridade ela também se apresenta por intermédio da linguagem, da palavra divina e dos mandamentos religiosos, e é justamente essa a marca que permite que ela seja uma conquista em relação ao elemento imediato da arte ao mesmo tempo em que se faz deficiente em relação ao pensamento e à filosofia propriamente dita.

O conteúdo da religião é presente nessa forma para mim. O que falta? Com respeito à forma, ela tem a forma da representação em contraste com o pensamento, e consequentemente, aparece como não necessária. Necessidade deve ser entendida nos termos do conceito e da liberdade (HEGEL, 1993, p.156)

Segundo Hegel, a religião marca uma maior interioridade em relação à arte no que diz respeito ao elemento da presença do sentido no figurativo, contudo, ela ainda tem uma falta, uma apresentação insuficiente em relação ao conteúdo que quer apresentar, o que faz com que ela, embora seja a consciência espiritual da verdade, não seja ainda a realização plena do espírito. Na religião o espírito alcança um distanciamento em relação ao figurativo, mas não o supera totalmente. Vejamos o que diz Hegel a respeito:

A forma distintiva na qual a verdade ocorre na religião foi bem definida como a
representação. Seu conteúdo, o mundo, Deus - é estabelecido por sua própria conta
e é trazido junto na forma da simplicidade, ainda que nela mesma tenha conteúdo
altamente multifacetado. Devemos considerar mais precisamente: a) o tipo de
conexão que essas representações mantém entre si mesmas, b) o tipo de conexão que
elas têm comigo, com meu ser interior e convicção, com meu conhecimento e saber
delas como minha essência (1993, pp.156 e 157)

Devemos entender o que essa afirmação diz sobre a forma da religião e no que ela guarda de figurativo, ao mesmo tempo em que isso se relaciona com a questão da linguagem. No que diz respeito ao primeiro ponto apontado por Hegel, isso é, da relação entre as representações entre elas mesmas, na forma religiosa o conteúdo é dito de maneira simples, sem que se demonstre a relação intrínseca que existe entre as partes.

A representação religiosa tem essencialmente a natureza de uma conexão que não pertence ao pensamento como tal, consequentemente, uma conexão representativa, uma conexão derivada da analogia, do figurativo, ou uma representação mais indeterminada de um certo modo de conexão (HEGEL, 1993, p.157)

Esse ponto é muito significativo no que diz respeito ao limite da elevação representativa em relação ao figurativo, pois mesmo que não faça mais recurso à imagem, a representação apresenta o conteúdo de uma maneira derivada do figurativo, do imediato, como diz a citação de Hegel. Os termos nos quais a religião apresenta a verdade do espírito para si mesmo ainda é feita de forma que, embora o que é narrado seja o verdadeiro, a forma 
de apresentação não é ainda adequada para o que narra. Em outras palavras, a verdade do espírito é a identidade do sujeito e do objeto no pensamento, mas como a religião apresenta isso como uma narrativa com partes e ideias derivadas de analogias com o imagético, ela ainda não pode apresentar a forma definitiva da identidade do sujeito e do objeto, o significante e o significado.

Os termos usados pela religião em sua narrativa apresentam o conteúdo ainda eivados por relações naturais, ou seja: não mostram os termos narrados na forma do conceito, que é a relação de necessidade entre os termos. Por exemplo: ““Criar” não é "fundamento” ou "causa": é algo mais alto que essas categorias do pensamento limitadas e contém a relação especulativa, a produção da ideia" (HEGEL, 1993, p.157). Através dessas figuras simples, não é possível entender o conteúdo especulativo em sua completude. E por quê?

Vimos anteriormente, na apresentação do conceito, que o que caracteriza o natural é justamente o elemento da alteridade. Na natureza a ideia se apresenta na forma da exterioridade onde tudo permanece idêntico a si mesmo e se relaciona com a multiplicidade a seu redor de forma puramente exterior. Ou seja, cada qual permanece idêntico a si mesmo na relação, não sendo possível apreender a dependência que cada figura mantém em relação às outras para sua própria determinação.

Quando a religião narra um fato, diz algo de maneira simples: A ação do pai, a criação do mundo, a ira de um espírito. Tudo isso, embora revele algo elevado, não permite, por exemplo, entender a relação intrínseca que existe entre o objetivo e o subjetivo, que é a verdade do espírito. O pai permanece sempre pai, assim como o filho. O mundo é o somente o mundo. Por essas palavras não se diz a relação de necessidade que o espírito quer manifestar de fato. Por isso, o religioso se mantém em um limite estreito da representação, muito embora consiga se manifestar de forma mais descolada que a intuição imediata, usando as palavras.

Klaus Vieweg expõe essa questão de maneira simples e clara.

Os pensamentos da negatividade e da maldade, por exemplo, encontram seu processo imagético em versões diferentes do "diabólico", tal como surgem no quadro de religiões distintas; algo semelhante vale para as representações sobre "criação". Deus se apresenta em formas variadas e mostra, assim [...] o cômico esquecimento de si e de sua natureza, a saber, por ter de ser principalmente tanto apenas um como também ao mesmo tempo muitos. A representação de Deus como sol, pai etc. é uma atribuição casual, já que nenhuma conexão conclusiva pode ser estabelecida com o pensamento de um absoluto, pois com legitimidade idêntica ele poderia ser chamado como terra, como mãe ou como Zeus (2007, pp.19 e 20) 
Segundo Hegel, "na representação o conteúdo permanece nessa relação consigo mesmo, não em conexão, não sob necessidade; e consequentemente, essa conexão figurativa, analógica, não é a do pensamento, não é posta como identidade na diferença” (1993, p.158). Essa identidade na diferença é o especulativo do qual tratamos anteriormente no primeiro capítulo quando abordamos a dedução das categorias umas às outras no sistema. $\mathrm{O}$ especulativo é justamente a unidade que perpassa a oposição, não como um instante separado, mas sim como um todo que mantém os momentos opostos como instantes essenciais de sua constituição. Veremos adiante que essa concepção é fundamental para apartar a religião da filosofia ${ }^{79}$.

Ainda sobre a questão da apresentação do conteúdo religioso, Hegel afirma um pouco adiante que

Por razão desse conteúdo sempre aparecer como algo exterior, marcado por uma
forma da exterioridade que é a falta de necessidade entre as partes, a religião assim o
conteúdo permanece para mim algo dado, que é chamado positivo e, na medida em
que se fala polemicamente, revelado, imediatamente dado, não compreendido. O
decreto eterno é equivalente à falta de conexão entre o universal e o particular. A
religião também permanece com representações gerais. Providência, sabedoria, os
desígnios de Deus são incompreensíveis (1993, p.158) se apresenta para nós sempre como algo dado, e como tal é um dogma. Para tanto, "o conteúdo tem e mantém a forma da externalidade contra mim" (HEGEL, 1993, p.158 e 159). Um pouco antes: “o fundamento da confirmação pertence à fé eterna” (HEGEL, 1993, p.158).

Essa marca da religião como um conteúdo sempre dado, sempre posto diante de nós se relaciona diretamente com a questão da figuração e da presença do sentido que mencionamos ao longo dessa exposição, mesmo porque o próprio Hegel não se cansa de colocar o religioso como um instante de superação do figurativo, mas de maneira que ainda mantém algo dele em si. E o figurativo na religião recai justamente na questão da prosa religiosa, na medida em que Hegel caracteriza o prosaico justamente como uma consciência que

considera a matéria ampla da efetividade segundo a relação intelectual de causa e efeito, finalidade e meio e outras categorias do pensar limitado, em geral segundo as

\footnotetext{
${ }^{79}$ Sobre a caracterização da exposição da religião, Klaus Vieweg afirma que "a religião tem na linguagem mitopoética, mais precisamente no texto mito-lógico, a espécie de comunicação que lhe é mais apropriada. Os componentes principais dessa narrativa são marcados por uma união meramente sintética do intuitivo-sensível e do conceitual; para Hegel, palavras como "Deus", "inferno", "criação", entre outras, valem como tais puras sínteses. Com a acentuação desse "puro sintético" devem ser marcados a força de realização e o limite do representar: temos uma unidade entre intuição e o conceito, de modo algum algo destituído de razão, mas também não ainda uma unidade fechada, perfeita. As representações, as imagens, oscilam eternamente entre ambos os polos da universalidade e da singularidade, que ainda não são colocadas em uma unidade especulativa, realiza-se uma constante tra-dução - metáfora - entre os lados” (VIEWEG, 2007, p.19). Essa afirmação acerca da realização de uma tradução na representação é primordial na nossa argumentação que se desenvolve a seguir.
} 
relações da exterioridade e finitude. Desse modo, cada particular surge, num certo momento, como autônomo, de modo errado, num outro momento, é trazido a uma mera relação com um outro e com isso é apreendido apenas em sua relatividade e dependência, sem que cada unidade livre se realize (2004, p.26)

Essa caracterização do prosaico condiz com a descrição da religião como representação nos manuscritos, como uma apresentação do conteúdo em elementos simples que não se mostram em sua relação mútua e necessária segundo a forma do conceito.

Ora, dissemos anteriormente que a Enciclopédia apresenta a representação como um instante no qual o sensível imediato é elevado à forma da universalidade. Essa caracterização se realiza na religião na medida em que o espiritual apresentado imediatamente pela arte não se faz mais suficiente para apresentar o espírito. A religião se consuma quando apresenta o espírito totalmente pela mediação do pensamento, mesmo que ainda de forma não conceitual. E ela se realiza como tal na religião cristã luterana. ${ }^{80}$

De qualquer forma, o que esse trajeto da religião revela é justamente o desprendimento em relação ao figurativo imediato, mas sua forma prosaica não consegue romper totalmente com a figuração, e essa explicação nos conduz diretamente para o ponto que Hegel aponta ser a deficiência do religioso em relação ao filosófico. Em que medida?

A compreensão desse problema da representação em relação ao pensamento foi exposta por Hegel já na primeira parte da Enciclopédia, exatamente quando se dedicou a analisar o pensamento. A compreensão do que é o pensar para Hegel passa por um distanciamento do que usualmente se entendia como tal, como vimos ao longo do primeiro capítulo. E essa crítica passa exatamente por caracterizar a representação. Vale a longa citação de Hegel a respeito:

Aqui o conteúdo é pensamento, tanto mais que também está presente a forma da
universalidade, já que convém que esteja por ser um conteúdo em mim, e de modo
geral por ser ele representação. Mas, em geral, a peculiaridade da representação deve
ser posta, também sob esse aspecto, em que tal conteúdo permanece igualmente
isolado em sua singularidade. [...] Nesse isolamento elas são simples: direito, dever,
Deus. Ora, a representação, ou fica nisto: em dizer que direito é direito, Deus é
Deus; ou então, mais cultivada, indica determinações - por exemplo, que Deus é
criador do mundo, onisciente, onipotente etc. Aqui estão em lista muitas
determinações simples isoladas, que apesar de sua ligação, que lhes foi assignada em
seu sujeito, permanecem fora uma da outra. A representação aqui coincide com o
entendimento, que só se diferencia dela por relações de universal e particular, de
causa e efeito etc., e por isso relações de necessidade entre as determinações

${ }^{80}$ Não é nosso propósito aqui discutir os pormenores da relação de Hegel com o cristianismo, pois isso demandaria um estudo específico só para abordar essa questão. Para a seguinte afirmação, seguimos somente o esquema que Hegel apresenta na exposição do sistema, seja na Enciclopédia ou nas preleções sobre a filosofia da religião. 
isoladas, da representação; enquanto essa as deixa em seu espaço indeterminado, uma ao lado da outra, ligadas pelo simples também (2005, pp.70 e 71).

Isso possibilita a seguinte conclusão: o domínio da representação se revela na religião na medida em que ela ainda opera sob o registro da distância entre o sujeito e o objeto, e isso surge porque diz as coisas de uma maneira simples como ditas pela passagem acima. Segundo as passagens que usamos do próprio Hegel nos manuscritos, esse procedimento é marcadamente figurativo. E porque o uso indiscriminado desse "também" para ligar determinações simples é figurativo e não permite à representação ser pensamento?

Para responder a essa questão devemos lembrar que a prosa da representação foi definida por Hegel na estética justamente nestes termos, em termos de determinações limitadas, e nessa relação, na relação da representação, ainda temos as coisas postas como um conteúdo que a inteligência possui. Por essa razão o representativo não consegue romper com a figuração e fazer presente o sentido como ser. Lebrun nos recorda que

\begin{abstract}
ao isolar os "pensamentos" e encadeá-los como simples objetos de conhecimento, dá crédito à ideia de que o Saber é uma estratégia "subjetiva". É óbvio então que, de direito, o "pensamento" é abstrato, que, de direito, os "conhecimentos" são parciais, que o domínio do "conhecer" está disjungido da prática. [...] Em suma, ele não se melindra por deixar outra coisa fora dele (2000, p.77)
\end{abstract}

Isso significa que a religião, mesmo em sua realização última no sistema que é o cristianismo protestante, ainda não consegue superar o nível da significação, pois ainda permanece em oposição com algo que se apresenta para a consciência de si como um objeto. Mesmo que mediado pela palavra, e, portanto, no domínio da linguagem, o protestante também não é capaz de se conciliar plenamente com Deus. Isso porque mesmo a linguagem, no domínio da representação ${ }^{81}$, não expõe a relação interior das determinações do que diz. Como Hegel mesmo expõe, no máximo ela pode produzir determinações simples como "Deus é criador", 'Deus é pai”, ou que Ele é onipotente.

Na religião persiste sempre um elemento de "profundidade", de algo insondável que não se pode alcançar. E isso é dito nos manuscritos: a presença de algo profundo e inalcançável é uma marca do figurativo na religião. E isso porque a linguagem em um primeiro instante, que é a primeira "conquista" da representação em relação ao sensível, nada

\footnotetext{
${ }^{81} \mathrm{O}$ que marca a linguagem no nível representativo é que funciona como uma abstração do sensível, mas não um distanciamento dele. Hans Belting faz menção à relevância da crença mesmo no domínio da linguagem quando diz que "há fé em jogo quando "damos a palavra" ou quando alguém "nos dá sua palavra". A fé também é cobrada, e, ao mesmo tempo, sancionada pela escrita. Ela fixa a palavra, na medida em que nos faz crer que podemos reproduzi-la." (BELTING, 2006, p.30). Muito embora sua posição não seja exatamente a de Hegel, é interessante notar a relação que ele traça entre a imagem e a linguagem na fé religiosa.
} 
mais é que uma abstração do conteúdo intuído, e não de fato uma superação dela, pois nesse nível representativo se dá o "dizer" o sensível. Vimos esse mecanismo na Enciclopédia quando a presença do imediato sensível é posta de lado na significação na simbolização e na significação. Entretanto, como lembra Lebrun,

\begin{abstract}
a base imediata que critica é simplesmente deixada de lado e conservada, em última instância, como suporte de seus conceitos. Daí o direito que Hegel se dá de reagrupar, sob o nome de Representação, instâncias díspares à primeira vista: com efeito, não há diferença de natureza entre a manifestação do conteúdo na superfície do sensível (a obra de arte) e o dizer do conteúdo, entre a unificação imaginativa e a separação significante/significado tal como a compreende o leitor ordinário (2000, p.82)
\end{abstract}

Nesse mesmo sentido. Jorge Díaz explica que:

\begin{abstract}
Assim, quando se predica de Deus que seja justo, bondoso, santo etc, temos somente modos de pensar sobre Deus, mas Deus mesmo permanece oculto, já que, enquanto tais predicados são sabidos, seu fundamento e essência, o sujeito mesmo não está todavia revelado, e igualmente as determinações do universal não são este universal mesmo (2007, p.28, tradução nossa)
\end{abstract}

E isso ocorre porque a palavra substitui a imagem como algo imediato, mas não suprime a referência a algo além do sentido posto. Desde o início do trajeto fenomenológico da consciência podemos notar que a palavra, no reino do universal, suprime o indicar. A natureza do espírito, contudo, que é a de ser verdade em si e para si mesmo, não se contenta com a simples substituição da imagem pela palavra, pois não se modifica o esquema de apresentar o imediato de alguma forma que indique que o sentido está além dele. Esse esquema não revela o pensamento que perpassa inclusive aquele que confere significação às palavras e aos objetos.

Dito de outra maneira, no reino da representação não se faz possível mostrar que o sujeito se forma ele mesmo nas suas matérias, que suas manifestações são manifestações dele mesmo. A linguagem e a religião conquistam um espaço em relação ao imediato, mas não mostram definitivamente a união do subjetivo com o objetivo. Retomando o já citado francês Gerard Lebrun, "se estamos satisfeitos ao receber como resposta o simples nome da coisa, é que estamos seguros de que a linguagem tem por função normal sinalizar um conteúdo já dado. E é pela mesma razão que a palavra poderá, em seguida, nos aparecer como um som vazio" (2000, pp.83 e 84).

Preencher esse vazio é lembrar à palavra o sensível ao qual ela faz referência. Hegel faz menção na Enciclopédia sobre a memória-que-conserva-os-nomes e a memória reprodutora. Isso é um avançar para além da simples significação que a representação 
consegue apenas entrever. Esse uso que a representação faz da língua é como se a usasse "simbolicamente", isso é, como sempre referindo a algo além dela que devesse ser explicado ou trazido à luz. Dito de outra forma, "o uso "simbólico" da palavra sugere assim que nunca estaremos no mesmo nível do saber, visto que é da natureza do signo impor ao leitor uma tarefa de interpretação e votar o locutor à felicidade da expressão" (LEBRUN, 2000, p.88).

A forma adequada ao conceito do espírito não pode ser, portanto, algo que se contente em ser um simples afastamento do sensível sem submetê-lo ao verdadeiro crivo do pensamento. Com a representação se dá somente um afastamento, mas não ao ponto de se criticar o que efetivamente constitui a exterioridade, que é a justaposição de termos e a consideração das partes determinadas de forma exterior.

O espírito de fato caminha para sua efetivação, e isso implica em superar seu viés subjetivo e objetivo. O espírito só é efetivo quando é subjetivo e também objetivo; não só em si, mas em si e para si também. No estágio representativo da religião, o espírito não consegue superar a concepção de que Deus é uma profundidade que é enormemente maior que ele. O culto, que é uma ação na direção do divino, não pode, consequentemente, promover uma verdadeira conciliação com Deus: ele precisa constantemente ser renovado. Em outras palavras, poderíamos dizer que a distância nunca é abolida verdadeiramente.

E a religião se situa como representação do espirito absoluto justamente porque ainda é uma tentativa de apresentar Deus para a consciência, como um significado que deve ser determinado e compreendido. É essa tentativa de expressar o conteúdo de uma maneira diferente, não estética, que faz a religião permanecer dentro dos limites da figuração, já que o máximo que consegue realizar como espírito é substituir a imagem estética pela mediação da palavra.

Enquanto houver um significado que deve ser apresentado para o próprio sujeito de uma forma mais de acordo com ele mesmo, ainda estaremos situados em um domínio no qual o conteúdo está apartado do sujeito em uma distância inconciliável. Por esse motivo, o representativo se distancia do imediato somente na medida em que seu meio de mediação é mais abstrato, mas não mais próximo do conceito. A representação somente deixa entrever que a presença do sentido não se dá no imediato, mas sim na forma do pensamento. Ainda seguindo Lebrun: “O significado não assombra o significante mais do que é, externamente, associado a esse último: ele é a explosão do significante como dotado daquela dignidade de uma instância autônoma, justificável por um exame em separado" (2000, p.90). 
Isso tudo é o argumento pelo qual entendemos, finalmente, o que Hegel quer dizer nas preleções quando critica o elemento figurativo da religião, não por ele ser "sensível" em demasia, mas mais notavelmente por sua necessidade de figurar o sentido, de apresentar uma forma de expressão do conteúdo para o próprio espírito. Ainda seguindo o raciocínio de Lebrun, podemos dizer que "se religiões e filosofias estavam inteiramente inconscientes da verdade que nelas se dizia, é que todas elas se figuravam como exprimindo um conteúdo" (2000, p.91).

Portanto, o pensamento que consegue unificar os opostos, consequentemente, deve mostrar que os signos e as produções do espírito não são simples ferramentas de um sujeito para desvelar o sentido do objetivo,

que eles não eram as aproximações do "significado" verdadeiro (...), mas, antes, dobras já em seu desdobramento, "momentos" já do conteúdo presente desde sempre. Ou ainda: enquanto a Representação acredita falar-sobre, essa fala sempre é situável no desenvolvimento daquilo que se fala (LEBRUN, 2000, p.91)

O que tem de diferente no pensamento de Hegel acerca da questão da representação e da figuração é que o pensamento expresso como uma representação ainda é uma tentativa de exprimir um conteúdo de melhor maneira, como se tentasse traduzir o conteúdo de uma forma mais específica, não compreendendo que ele mesmo, o sujeito que tenta traduzir o conteúdo, é ele mesmo apresentado por essa forma que ele julga utilizar.

Por isso mesmo, na filosofia não se trata de "traduzir" ou "transpor" o conteúdo da religião e da arte para uma forma mais elevada e adequada ao conceito, pois isso mesmo seria uma figuração, uma tentativa de formular um sentido para o conteúdo.

\footnotetext{
filosofar não é traduzir, mas fazer explodir a ingenuidade dos que abordam o conteúdo como se fosse algo de traduzível - dos que imaginavam poder transcrever ou desvelar aquilo cuja natureza é manifestar-se (sich offenbaren), isso é, suprimir as estruturas de transcrição ou de desvelamento (LEBRUN, 2000, p.92)
}

Isso é muito pertinente ao que Hegel insiste durante toda sua obra, que o espírito é tanto o sujeito quanto o objeto. Tudo é razão, mesmo nas formas ainda inacabadas do conceito; são estágios de seu desenvolvimento como razão. Tal é o sentido da afirmação de Hegel logo no prefácio da Fenomenologia do Espírito quando diz que o pensamento não especulativo, a filosofia de seu tempo que "acha que qualquer esclarecimento a respeito do sistema só pode ser uma ou outra. Não concebe a diversidade dos sistemas filosóficos como desenvolvimento progressivo da verdade, mas só vê na diversidade a contradição" (HEGEL, 2002, p.26). 
A religião como estágio representativo, como consciência da verdade, entende que há contradição na oposição sujeito-objeto. Como estágio da interioridade, da confirmação do sentimento, ela avança para uma forma na qual o conteúdo não pode ser simplesmente sentido, dado imediatamente, mas deve ser mediado pelo pensamento, abolindo a diferença entre o sujeito e o objeto ${ }^{82}$. Entretanto, como vimos, nunca se dá a conciliação pelo elemento religioso, por todos esses motivos que tratamos de expor acima. Já na Enciclopédia a passagem da memória para o pensamento é justamente a percepção de que as construções do sujeito não precisam de referência a algo exterior ao pensamento. Mas esse estágio já está fora da representação mesmo.

\begin{abstract}
A posição da religião consiste em que a manifestação daquela verdade, que através dela chega até nós, é verdade exterior ao homem; pelo que se sustenta que o homem se deve contentar na sua própria humildade, uma vez que a sua razão humana por si mesma é incapaz de alcançar a verdade. É caráter da religião positiva o admitir que as suas verdades existem por si, embora se não saiba donde vieram; de sorte que o conteúdo, quando dado, está acima e além da razão (HEGEL, 1980, p.366)
\end{abstract}

A religião em sua formulação mais acabada é a que consegue compreender essas questões e trazê-las diante de si mesma. Isso é, é a religião que explicita para si própria a substância que se faz finita e finalmente se anula como particularidade e se faz sujeito, que é a verdade de ambos os lados. Essa verdade é exposta em Deus como criador, a substância, que se faz finita em seu Filho, Cristo, que finalmente se reconcilia com a substância em sua morte e ressurreição como Espírito Santo.

Mas o fato de expressar a verdade nessa forma, como vimos, é uma marca deficiente da religião, na forma como dito por Hegel ao término da exposição do conceito de religião nos manuscritos: "A distinção da religião da filosofia e da arte aparece ela mesma primeiramente na religião absoluta, onde a religião consuma a si mesma em sua determinação. Determinação é conteúdo" (1993, p.163). Ou seja: A religião consegue consumar seu conceito; de apresentar o espírito como unidade do finito e do infinito, mas não é capaz de superar o distanciamento entre o sujeito e o objeto em sua forma, embora o conteúdo seja já o da filosofia especulativa.

\footnotetext{
${ }^{82}$ Conforme explicação de Jorge Díaz, "cada uma das religiões que precederam o cristianismo significaram um passo no processo de conceber a divindade como autoconsciência, quer dizer, à imagem e semelhança do ser humano, de modo que, quando Deus se faz homem o processo chegou à sua culminação. [...] A história das religiões é a história "do retorno de toda essencialidade à consciência", em outras palavras, o mesmo processo do saber especulativo: fazer com que toda exterioridade se converta na consciência mesma, de modo que a realidade em último termo tenha a mesma configuração que a consciência, quer dizer, que o sujeito e o objeto se identifiquem." (DÍAZ, 2007, p.27, tradução nossa). A forma das religiões, segundo o esquema proposto por Hegel confluem para a forma da encarnação de Deus proposta no cristianismo, pois ela é a representação da conciliação do singular com o universal.
} 
No caso da religião revelada (também chamada "religião consumada", por ser o momento máximo da representação no espírito) a reconciliação entre o subjetivo e o objetivo é posta como objeto da própria representação, e por isso é que no cristianismo tem-se consciência do especulativo, mas ele ainda é apresentado como representação.

Por fim, é abordada a representação da reconciliação, a criação de uma unidade de conteúdo efetiva, completa, presente entre o singular e o universal. Nesse ponto nevrálgico pode ser tornado nítido o argumento conclusivo de Hegel: na imediatidade da própria representação surge a possibilidade de mediação, ou seja, a indicação no sentido de uma indicação antecipadora da necessidade da tradução no saber conceitual, no sentido de um caminho do apreender [Ergreifen] para o conceitualizar [Begreifen] (VIEWEG, 2007, p.29)

Isso quer dizer que mesmo na religião cristã a elevação da intuição imediata de Deus até a representação tem na morte de Cristo seu primeiro passo. O cristianismo não é capaz de conciliar o singular com o universal porque o projeta no tempo. De fato, como nos recorda Díaz, "essa consciência mantém, contudo, o caráter de representação porque projeta esse conteúdo fora dela mesma em um passado e um futuro: na vida, morte e ressurreição de Cristo no passado e na futura salvação escatológica" (2007, pp.27 e 28, tradução nossa).

O mesmo estudioso colombiano da obra de Hegel resume de maneira precisa a distância entre o representar e o conceituar que distancia a religião da filosofia, mesmo no caso da religião cristã. Vale a longa citação:

Podemos assim compreender a diferença que estabelece Hegel entre a representação e o conceito. Para a primeira, o objeto do conhecimento é algo imediato, ou mediado de maneira imperfeita, já que se mostra como estranho e oposto à consciência, de modo que se faz presente como algo outro para ela, e seus elementos se mostram igualmente como diversos e dispersos entre si. [...] O conceito, por sua vez, retoma tais elementos, e com eles o objeto mesmo, para compreendê-los como momentos de sua própria constituição. Para a qual a autoconsciência deverá estender-se até poder abarcar dentro de si esse momento de alteridade (2007, p.30, tradução nossa)

Após termos exposto essas questões acerca da representação, podemos compreender também em que medida a religião ainda guarda em si algo do tempo. Já vimos que a forma de exposição do acontecimento do espírito na religião acontece como uma história mitológica. Também expomos que as determinações expostas nessa forma conservam o "também" das partes envolvidas nessa narrativa. Se lembrarmos das palavras de Hegel no §258 da Enciclopédia de que o tempo é "o vir-a-ser intuído, isto é, [tal] que são determinadas as diferenças simplesmente momentâneas, isto é [as que] imediatamente se suprassumem como exteriores, isto é, que são apesar disso exterior a si mesmas" (1997, §258, p.54), entendemos que a compreensão do espírito como uma história mantém a temporalidade no conteúdo, já que os elementos dessa narrativa são mostrados em uma unidade consigo mesmo, de forma 
que são, assim como o tempo as revela, exteriores a si mesmas. O universal que se particulariza é mostrado como o Pai que tem um filho, mas o pai é simplesmente pai, na mesma medida em que o filho é só o filho. Portanto, o fato de entender a realização do espírito como um devir, como uma história, revela uma marca primordial da natureza que é o tempo. O representativo da religião é justamente a permanência da temporalidade, desse "também" que marca a simultaneidade das determinações que passam umas às outras na narrativa mitológica. Segundo a explicação de Paulo Arantes, "o devir é a unidade negativa do ser e do não-ser, enquanto o tempo é essa mesma unidade negativa, como função lógica, entre o ser e o não-ser, mas posta no domínio da exterioridade, na esfera do ser-fora-se-si da Ideia" $\left(2000\right.$, p.87). ${ }^{83}$

Consequentemente, enquanto o culto e a religião não permitem que se compreenda a própria comunidade como realização e parte de Deus, a ação religiosa permanece no campo da representação, da salvação projetada no futuro como realização de algo posto no passado. "Isso significa que Deus e a comunidade crente sejam diferentes, mas que sejam no sentido de que essa última venha a ser a realização concreta daquele” (DÍAZ, 2007, p.31).

\footnotetext{
${ }^{83}$ Vimos que o conceito é a presentificação do sentido para si mesmo, sem a distância da significação. Portanto, no nível do conceito e do pensamento especulativo, não há essa abstração do tempo, pois se anula essa passagem de um para outro, do objeto para o sujeito, que caracteriza a passagem do tempo, do devir. No conceito o sentido é plenamente presente para si mesmo. Ainda sobre esse assunto, vale o esclarecimento, novamente de Paulo Arantes que se dispôs a caracterizar pormenorizadamente o problema do tempo em Hegel: "O tempo é puro devir, como intuído. O tempo é mudança pura, é o conceito puro, o simples, que tira sua harmonia dos opostos absolutos. Sua essência é ser e não-ser, sem nenhuma outra determinação" (2000, p.90).
} 


\section{CONSIDERAÇÕES FINAIS}

Após termos percorrido as páginas dos manuscritos sobre a filosofia da religião nas quais Hegel expõe o seu conceito de religião, pudemos perceber que a questão da religião em Hegel envolve muito mais que uma simples manifestação religiosa, pois seu sistema de pensamento confere à religião um papel importante na realização do que ele chama de espírito, a unificação do subjetivo e do objetivo operada pelo próprio pensamento.

$\mathrm{Na}$ introdução ao presente texto, expusemos que o problema da representação na filosofia da religião surge como uma questão que vai além do próprio problema religioso, pois, muito embora tenha se originado em larga medida nas discussões sobre a religião, acabava por envolver toda a relação do pensamento de uma época com a própria capacidade de conhecer o mundo a si própria. A questão da representação no sistema está ligada diretamente ao problema da mediação entre o absoluto e o individual, cuja solução Hegel buscou durante vários textos ao longo de sua carreira até a concepção do sistema especulativo.

Justamente por envolver um esquema sistemático, em linhas gerais indicamos no primeiro capítulo o funcionamento do sistema especulativo para expor que a mudança que Hegel pretendia conquistar em relação a seus antecessores passava por uma forma diferente de se conceber o pensamento. Para alcançar o absoluto e suprimir a distância entre o sujeito e o objeto, não deveríamos somente ignorar o entendimento e pregar o acesso imediato a um absoluto vazio, mas sim compreender o negativo do entendimento como momento da realização do próprio pensamento. Para isso, claro, seria necessário construir um sistema no qual o próprio mundo é manifestação desse pensamento, no qual as categorias do pensar e do mundo se deduzem umas das outras. Nesse sentido, a religião deve se ajustar a esse sistema de um pensamento autorreferente, razão pela qual o tratamento que Hegel dispensa à religião não é de uma simples teologia ou de uma pregação em especial ${ }^{84}$, mas sim um tratamento que

\footnotetext{
${ }^{84}$ Muito embora não tenha sido a intenção expressa de Hegel de fazê-lo, como deixou claro em diversas passagens ao longo de suas preleções em Berlim, sua filosofia desencadeou muitas implicações teológicas. É digno de nota que muitas questões de sua filosofia ainda levantam questões dentro dos estudos de teologia. Apenas por curiosidade, citamos o influente teólogo protestante Karl Barth, cuja teologia debate com Hegel diversas posições, especialmente a historicidade de Deus e da humanidade. Também Jorge Diaz, no artigo citado aqui algumas vezes intitulado "Hegel Y La Superación de La Religion", sustenta que a posição de Hegel de caracterizar a religião como uma ligação imediata com Deus pode caracterizar uma espécie de "mística religiosa". Sobre a importância da repercussão religiosa da obra de Hegel, vale lembrar o testemunho de Karl Löwith, que lembra que "é significativo para a separação da escola hegeliana, em uma direita de velhos hegelianos e uma esquerda de jovens hegelianos, que ela não tenha nascido de diferenças filosóficas puras, porém de diferenças políticas e religiosas" (LÖWITH, 2013, p.61).
} 
diz respeito ao que a religião consegue manifestar nos termos da filosofia idealista que propõe.

A religião, portanto, como parte integrante do desenvolvimento do espírito, segundo Hegel, se constitui no momento no qual o espírito se dá conta, por assim dizer, de que não se pode compreender a si próprio imediatamente; o objetivo deve ser mediado pela interioridade, e esse é o momento religioso, o instante da confirmação interior do absoluto. Essa unificação conduz, por sua própria dinâmica interior para a diferenciação promovida pela reflexão, até que a figuração e a tradução presentes na religião se mostrem insuficientes para o que pretendem expressar, de modo que temos a passagem para o conceito e a filosofia.

Dado que Hegel insiste que o que faz da religião um campo representativo e, portanto, diferente da filosofia, é justamente a persistência de um elemento do figurar, do traduzir; é uma tentativa de adequar a forma a um sentido sempre apartado do sujeito que ele pretende $\operatorname{mostrar}^{85}$. No campo do conceito, como vimos, não há mais tradução em uma forma superior, mas sim que a "superioridade" do conceito consiste justamente em que ele não é mais um traduzir, mas um compreender as outras figuras como momentos da constituição do sujeito. Assim, nesse nível, caem as oposições; o pensamento se compreende totalidade e se vê em todos os momentos compreendendo a si próprio em seu desenvolvimento.

Tendo isso em vista, isto é, que a religião é uma etapa na realização do pensamento em sua própria identificação consigo, fica a pergunta de como essa consideração de Hegel acerca da religião pode ainda ser relevante nos dias de hoje. As consequências desse tipo de consideração têm implicações diversas, não só para a consideração racional da religião, mas também acerca do próprio pensamento. Em relação à religião e ao pensamento, o sistema de Hegel possibilita que vejamos, através da crítica da religião e da fé, que o verdadeiro pensamento não é oposto ao pensamento religioso. O ponto principal que colocamos ao longo

\footnotetext{
${ }^{85}$ Esse resultado da filosofia de Hegel que diferencia a filosofia da religião somente pela forma é rejeitado por Feuerbach, um dos representantes da chamada "esquerda hegeliana" justamente por entender que ambas as figuras diferem essencialmente e não formalmente. Feuerbach ilustra uma crítica que foi endereçada a Hegel diversas vezes, na qual essa identificação, no final das contas, acaba por destruir completamente a particularidade que a religião possui frente ao pensamento conceitual. Como por exemplo: "objetei à filosofia hegeliana que ela tornava supérfluo o essencial da religião e inversamente essencial o supérfluo, e que a essência da religião é exatamente aquilo que a filosofia transforma em mera forma. [...] A religião não contém somente, como afirmou Hegel, imagens fantásticas e afetivas de pensamentos especulativos, mas antes um elemento diverso do pensamento, e este não é uma mera forma e sim sua essência. [...] Podemos então reduzir a diferença entre a filosofia e a religião simplesmente em que a religião é sensorial, estética, enquanto que a filosofia é algo suprassensível, abstrato" (FEUERBACH, 2009, pp.24 e 25). Esse ponto defendido por Feuerbach, contudo, só pode fazer sentido contra Hegel ignorando-se justamente os pressupostos sistemáticos que conduzem Hegel a diferenciar religião e filosofia somente pela forma. Na medida em que Feuerbach rejeita o elemento especulativo da razão, não teria como aceitar a unificação promovida pelo pensamento entre as duas figuras.
} 
desse texto é que o conteúdo do pensamento conceitual é o mesmo que o da religião, diferindo somente em sua forma.

Em um primeiro instante compreendemos que à forma da religião falta a compreensão de que suas sínteses são justamente isso mesmo: meras sínteses; de que seus elementos se reúnem de forma não necessária, nos quais cada termo mantém sua unidade consigo mesmo sem a percepção do pensamento que é a unidade dos opostos. No estágio religioso, a passagem do universal para a particularidade é apresentada na forma de uma mitologia, ao passo que na filosofia e com o pensamento essas passagens são entendidas como a dinâmica própria do conceito. Ora, se a religião deve ser superada como forma em prol do conceito, isso se dá justamente porque a própria religião precisa de uma forma mais adequada de legitimação de conteúdo que ela pode apresentar.

Quando compreendemos, já no nível do conceito, que a filosofia e o pensamento não são formas mais adequadas e perfeitas de traduzir o conteúdo para a consciência, compreendemos também que não se trata de construir discursos que possuam conteúdo mais ou menos verdadeiro. $\mathrm{O}$ que se realiza no conceito é justamente o saber de que o pensamento livre de qualquer figuração ou limitação formal é o próprio Deus, que o mundo é o próprio pensamento que sai de si mesmo e constrói uma realidade de si, tal como exposto no esquema da ideia na Ciência da Lógica.

Esse pensamento é compartilhado por Klaus Vieweg que comenta, acerca da relação da religião com a filosofia no pensamento hegeliano, que

\footnotetext{
o pensamento livre mostrou-se como divino e o conteúdo absoluto, divino, mostrouse na forma do conceito a ele adequado, como pensamento conceitual. [...] Os momentos do movimento do espírito não são mais figuras da consciência ou representações, e sim conceitos determinados, momentos na determinação de si mesma do conceito (2007, p.31)
}

Isso implica que quando se chega no nível do conceito, entendemos o elemento religioso e artístico como momentos imprescindíveis na construção do mundo e da consciência que temos dele. No mundo moderno da liberdade, o conflito entre um discurso religioso e o pautado nas ciências particulares revela toda a envergadura do problema tratado por Hegel em sua filosofia da religião.

Na medida em que a religião não é um discurso vazio, o pensamento que rejeita completamente o que há a ser dito pelas tradições religiosas acaba por ser um discurso que 
derrapa em sua própria pretensão de racionalidade que é capaz de dar conta de todo o real. Segundo o mesmo Vieweg,

a religião não é um modelo ultrapassado, não é mera herança da tradição em um mundo que se mundanizou totalmente. Tal entendimento que hoje encontramos muitas vezes (pois com a forma ele despreza também o conteúdo) não compreende o substancial das religiões autênticas, faz delas uma forma destituída de conhecimento, exatamente como a religião do sentimento compreende o saber, com sua tese de exclusão. Nesse clima de discursos mudos [Aneiander-Vorbei-Reden] entre a religião destituída de razão e do entendimento destituído de razão, reside um problema fundamental do mundo moderno, uma deficiência, que Hegel procura enfrentar com o pensamento da unificação verdadeira de ambos os lados, com o conceito da tradução recíproca entre linguagem da representação e do conceito $(2007, \text { p. } 23)^{86}$

Nessa medida, a filosofia da religião de Hegel nos parece fundamental não somente para apontar para a importância da religião como um instante inafastável da formação do espírito, mas muito mais para fundamentar uma crítica às formas de pensamento modernas, pois nos parece que a que está em jogo para Hegel não é tanto assim um problema da religião, mas sim uma limitação do pensamento ao se deparar com os temas da religião.

As múltiplas configurações do mundo contemporâneo certamente precisam da forma do conceito que legitimam a multiplicidade, mas não se pode ignorar o artístico e o religioso desse mundo, justamente porque são parte do estofo que o conceito deve fundamentar ${ }^{87}$. Talvez seja esse o ponto citado por Vieweg de que "rejeitando a forma se rejeita o conteúdo", pois uma lição importante que podemos tirar das considerações de Hegel sobre a religião é que o pensamento não pode dar conta de fato do real se ele se dispensa de meditar sobre uma parte dele.

\footnotetext{
${ }^{86}$ Embora aqui o comentador faça uso do termo "tradução", que criticamos ao longo da dissertação, entendemos que o sentido aqui usado não conflita com o que foi exposto antes, pois o que está dito aqui é justamente a necessidade, no nível do conceito, de se compreender a mútua implicação do discurso religioso e o conceitual, e não uma simples "tradução" (no sentido criticado) de um pelo outro.

${ }^{87}$ Muitos autores contemporâneos colocam o problema da oposição da religião com o discurso "científico" como pauta em suas discussões mais importantes. Dentre eles destacamos Habermas, que apesar de sua inspiração declaradamente kantiana, dialogam com o ponto de vista de Hegel em diversas passagens. Dentro desse tema, vide (HABERMAS, Fé e Saber, trad. Fernando Costa Matos. São Paulo, Editora Unesp, 2012) e (HABERMAS, Entre o Naturalismo e a Religião, trad. Flavio Siebeneichler. Rio de Janeiro: Editora Tempo Brasileiro, 2007). Ainda sobre os reflexos do pensamento sobre a religião de Hegel na filosofia do século XX, podemos encontrar ressonâncias da crítica à rejeição do absoluto no seio da vida no pensamento de Walter Benjamin, muito embora ele não cite Hegel diretamente. O problema, contudo, como pudemos verificar ao longo do presente texto, é o mesmo. Vejamos: "Somos irreligiosos porque não mais observamos em lugar algum o persistir. O Sr. Percebe como se está demolindo o fim em si, essa santificação última do fim? Como cada coisa particular que não é reconhecida clara e honestamente se converte em "fim em si"? Por sermos deploravelmente pobres em valores, isolamos tudo. Em decorrência, faz-se da necessidade uma virtude obrigatória. Arte, ciência, esporte, convívio social - esse divino fim em si desce até o indivíduo mais andrajoso. Cada qual representa algo, significa algo, é único" (2013, p.32).
} 
E é essa consideração que nos faz pensar que a filosofia de Hegel ainda pode contribuir, em larga medida, para a filosofia contemporânea em sua tentativa de compreender nosso mundo. 


\section{REFERÊNCIAS BIBLIOGRÁFICAS:}

Obras de Hegel:

HEGEL, G.W.F “Vorlesungen über die Philosophie der Religion” Neu herausgegeben von Walter Jaeschke. Hamburg : Felix Meiner, 1993.

"Lectures on the Philosophy of Religion". Volume I. Introduction and the

Concept of Religion. Edited by Peter Hodgson. Oxford, Oxford University Press, 2007.

“Lectures on the Philosophy of Religion”. Volume II. Determinate Religion.

Edited by Peter Hodgson. Oxford, Oxford University Press, 2007.

"Lectures on the Philosophy of Religion". Volume III. The Consummate Religion. Edited by Peter Hodgson. Oxford, Oxford University Press, 2007.

"Leçons sur la philosophie de la religion", Première partie, Introduction - le concept de la religion / Georg Wilhelm Friedrich Hegel. Trad. Pierre Garniron. Paris: Presses Unversitaires de France, 1996.

Fé e Saber. Trad. Oliver Tolle. São Paulo: Hedra, 2007.

Fenomenologia do Espírito. $3^{\mathrm{a}}$ Ed. Trad. Paulo Meneses. Petrópolis. Ed.

Vozes 2002.

Ciência da Lógica, Excertos. Trad. de Marco Aurélio Werle, São Paulo:

Barcarolla, 2011.

Ciência da Lógica. 1: A Doutrina do Ser. Trad. Christian Iber, Marloren Miranda e Federico Orsini. Petrópolis: Editora Vozes, 2016.

Enciclopédia das Ciências Filosóficas. $1^{a}$, A ciência da Lógica, $2^{\text {a }}$ Ed. Trad.

Paulo Meneses. São Paulo: Edições Loyola, 2005.

Enciclopédia das Ciências Filosóficas. $2^{a}$ parte, Filosofia da Natureza,

Trad. Pe. José Nogueira Machado. São Paulo: Edições Loyola, 1997. 
Enciclopédia das Ciências Filosóficas. 3 parte, Filosofia do Espírito. Trad.

Paulo Meneses, São Paulo: Edições Loyola, 1995.

Lectures on the Proofs of the Existence of God. Edited and translated by

Peter Hodgson. Oxford: Clarendon Press, 2007

Cursos de Estética. Trad. Marco Aurélio Werle e Oliver Tolle. São Paulo:

Edusp, 2001.

. Introdução à História da Filosofia. In: Os Pensadores. Trad. Antonio Pinto de Carvalho. São Paulo, Abril Cultural, 1980.

Demais artigos e obras complementares:

AQUINO, M.F. “O Conceito de Religião em Hegel.” São Paulo: Edições Loyola, 1989.

ARANTES, P. “Hegel e a Ordem do Tempo”. São Paulo: Editora Hucitec, 2000.

BECKENKAMP, J. A Penetração do Panteísmo na Filosofia Alemã. In: "O que nos faz pensar". $\mathrm{N}^{\circ} 19$, fevereiro de 2006.

O Jovem Hegel. Formação de um Sistema Pós-Kantiano. São Paulo: edições

Loyola, 2009.

BENJAMIN, W. O Capitalismo Como Religião. Trad. Nelio Schneider. São Paulo: Boitempo Editorial, 2013.

BELTING, H. “A Imagem Autêntica.” In: Humboldt n92. São Paulo: Goethe Institut, 2006.

BOURGEOIS, B. "Os Atos do Espírito”. Trad. Paulo Neves. São Leopoldo: Editora Unisinos, 2004.

BURBRIDGE, J. “The Logic of Hegel's Logic”. Quebec, Broadview Press, 2006.

CHAPELLE, A., Hegel et la religion, 3 vols. Paris: Editions Universitaires, 1964-71. 
DIAZ, J.A "Hegel $\quad$ y $\quad$ La religión”. http://www.bdigital.unal.edu.co/1436/10/09CAPI08.pdf. "Hegel y la superación de la Religión”. In: dialnet.unirioja.es/descarga/articulo/2292252.pdf, 2007.

FICHTE, J. A Doutrina da Ciência. Trad. Rubens Rodrigues Torres Filho. Coleção "Os Pensadores”. São Paulo: Abril Cultural, 1980.

FEUERBACH, L.A., Preleções Sobre a Essência da Religião. Trad. José Brandão. Petrópolis: Editora Vozes, 2009.

GOETHE, J.W . "Memórias: Poesia e Verdade". Trad. Leonel Vallandro. Brasilia: Editora UnB: 1986.

HAMELIN, O. Essais sur le Elements Principaux de la Representation. Presses Universitaire de Paris.

HAYM, R. Hegel und Seine Zeit. Hildesheim : G. Olms, 2007.

HODGSON, P., Hegel and Christian Theology. A reading of the Lectures on the Philosophy of Religion. New York: Oxford University Press, 2005.

HÖSLE, V. O Sistema de Hegel. O Idealismo da Subjetividade e o Problema da Intersubjetividade. Trad. Antonio Pinto de Lima. São Paulo: Edições Loyola, 2007.

HABERMAS, J. "Entre naturalismo e religião" . Trad. Flavio Siebeneichler. Rio de Janeiro: Tempo brasileiro, 2007. . "Fé e Saber". Trad. Fernando Costa Matos. São Paulo, Editora Unesp, 2012.

HYPPOLITE, J. Gênese e Estrutura da Fenomenologia do Espírito de Hegel. $2^{\mathrm{a}}$ Ed. São Paulo: Discurso Editorial 1999.

JACOBI, F.H. "Über die Lehre des Spinoza in Briefen an den Herrn Moses Mendelssohn." Hamburg : Felix Meiner, 2000. 
JAESCHKE, W. Hegel Handbuch. Stuttgart: J.B. Verlag, 2003. . Die Vernunft in der Religion. Spekulation und Erfahrung. Texte und Untersuchung zum Deutschen Idealismus. Abteilung II: Untersuchung. Stuttgart-Bad Cannstatt: frommann-holzboog, 1986.

Reason In Religion. The Foundation of Hegel's Philosophy of Religion. Trad. Peter Hodgson and Michael Stewart. Oxford: University of California Press, 1990. . "O Sistema da Razão Pura". In: O Pensamento Puro Ainda Vive: 200 anos da Lógica de Hegel. Org. Marcia C.F. Gonçalves. São Paulo: Editora Barcarolla, 2014.

KANT, I., Crítica da Razão Pura. Coleção “Os Pensadores”. Trad. Valério Rohden. São Paulo: Editora Nova Cultural, 1999.

. Crítica da Razão Prática. Edição Bilíngüe. Trad. Valério Rohden. São Paulo: Editora Martins Fontes, 2003.

KNOLL, V. "História, religião e arte", in Tempo Social: Rev. Sociol. USP, S. Paulo, 8 (2): 105-117, outubro de 1996.

LEBRUN, G. A Paciência do Conceito. Ensaio sobre o Discurso Hegeliano. Trad. Silvio Rosa Filho. São Paulo: Editora Unesp, 2000.

LÖWITH, K. "De Hegel a Nietzsche. A ruptura revolucionária no pensamento do século XIX Marx e Kierkegaard.'Trad. Flamarion Caldeira Ramos e Luiz Fernando Barrére Martin. São Paulo, Editora Unesp, 2013.

MARCUSE, H. "Razão e Revolução. Hegel e o Advento da Teoria Social”. Trad. Marilia Barroso. São Paulo: Editora Paz e Terra, 2004.

MÜLLER, M. "A negatividade do começo absoluto". In: O Pensamento Puro Ainda Vive: 200 anos da Lógica de Hegel. Org. Marcia C.F. Gonçalves. São Paulo: Editora Barcarolla, 2014.

PERTILLE, J. "A Faculdade do Pensar e as Faculdades do Espírito.” In: Revista Eletrônica de Estudos Hegelianos, $\quad n^{\circ} 13, \quad 2010 . \quad$ In: http://ojs.hegelbrasil.org/index.php/reh/article/view/37. 
PÖGELLER, O.(Hg.) Hegel. Einführung in seine Philosophie. München: Verlag Karl Alber, 1977.

PEREIRA, R.H.S “Representação e Ceticismo”. In: Discurso n³9: 25 - 58, São Paulo, Barcarolla, 2011.

SCHALHORN, C. Hegels enzyklopädischer Begriff von Selfbewußtsein. Hamburg: Felix Meiner Verlag, 2000.

SCHELling, F.W.J. Os Pensadores. Trad. Rubens Rodrigues Torres Filho, São Paulo: Nova Cultural, 1991.

SESBOÜÉ, B. História dos Dogmas: O Deus da Salvação. $2^{\mathrm{a}}$ ed. Trad. Marcos Bagna. São Paulo: Edições Loyola, 2005.

STEDEROTH, D. "Casamento malogrado - a noiva está morta!? Sobre a Transição da Natureza para o Espírito em Hegel.’Trad. Darice Zanardini. In: Revista Eletrônica de Estudos Hegelianos, nº13, 2010. In: http://ojs.hegelbrasil.org/index.php/reh/article/view/36.

TAYLOR, C. “Hegel”. Trad. Nelio Schneider. São Paulo: É Realizações, 2014.

TORRES FILHO, R.R. Dogmatismo e antidogmatismo: Kant na sala de aula. In Ensaios de Filosofia Ilustrada. São Paulo: Iluminuras, 2004.

A Produção Extrateórica da Síntese. In Ensaios de Filosofia Ilustrada. São Paulo: Iluminuras, 2004.

VIEWEG, K. Religião e Saber Absoluto. A passagem da Representação para o Conceito na Fenomenologia do Espírito. Trad. Marco Aurélio Werle. In: Cadernos de Filosofia Alemã X. São Paulo: 2007.

WERLE, M. A. “A poesia na estética de Hegel”. São Paulo: Associação Editorial Humanitas: FAPESP, 2005. 
. "O conceito como duplicidade na unidade”. In: O Pensamento Puro Ainda Vive: 200 anos da Lógica de Hegel. Org. Marcia C.F. Gonçalves. São Paulo: Editora Barcarolla, 2014.

. "A Elevação do Espírito Pensante a Deus, ou a Natureza Lógica do Conceito nas Preleções de Hegel sobre as provas da Existência de Deus”. Veritas Porto Alegre v. 55 n. 3 set./dez. 2010 p. 178-185.

WINFIELD, R.D. “From Concept To Objectivity”. Burlington: Ashgate press, 2006. 